LA--12098-MS

DE91 015788

Results of Investigations at the

Zunil Geothermal Field, Guatemala:

Well Logging and Brine Geochemistry

Andrew Adams

Bert Dennis

Ed Van Eeckhout

Fraser Goff

Robert Lawton

P. E. Trujillo

Dale Counce

Victor Medina*

J. Archuleta 


\section{DISCLAIMER}

This report was prepared as an account of work sponsored by an agency of the United States Government. Neither the United States Government nor any agency Thereof, nor any of their employees, makes any warranty, express or implied, or assumes any legal liability or responsibility for the accuracy, completeness, or usefulness of any information, apparatus, product, or process disclosed, or represents that its use would not infringe privately owned rights. Reference herein to any specific commercial product, process, or service by trade name, trademark, manufacturer, or otherwise does not necessarily constitute or imply its endorsement, recommendation, or favoring by the United States Government or any agency thereof. The views and opinions of authors expressed herein do not necessarily state or reflect those of the United States Government or any agency thereof. 


\section{DISCLAIMER}

Portions of this document may be illegible in electronic image products. Images are produced from the best available original document. 


\section{CONTENTS}

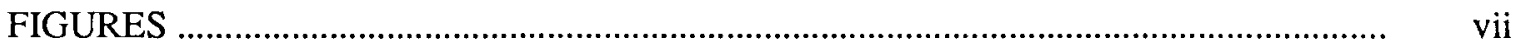

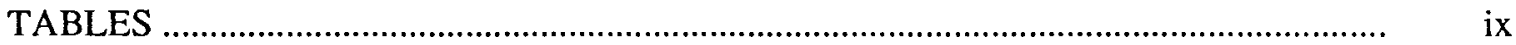

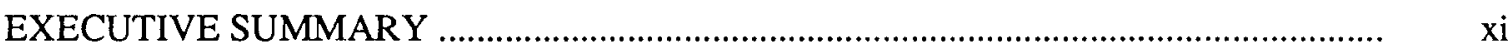

RESUMEN EJECUTIVO …..............................................................................

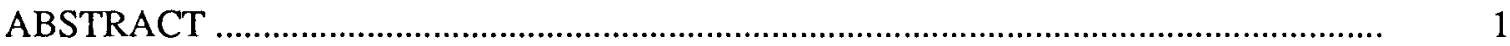

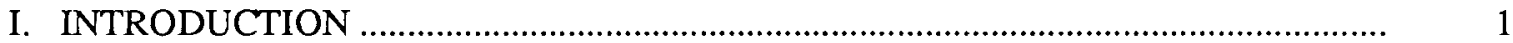

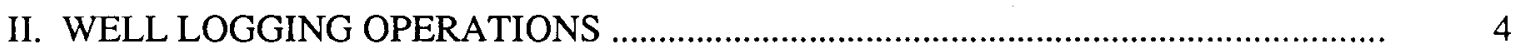

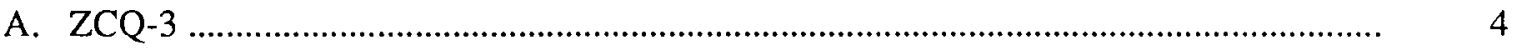

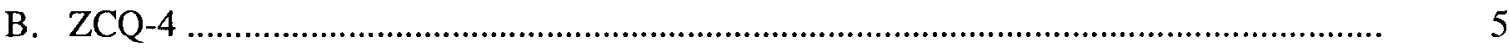

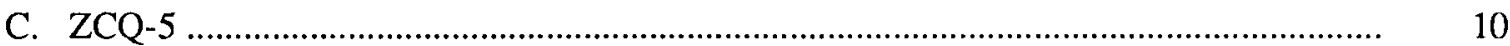

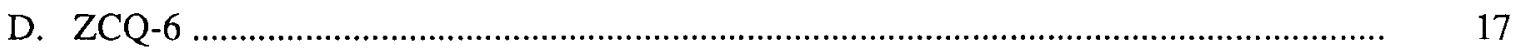

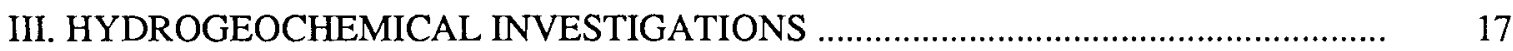

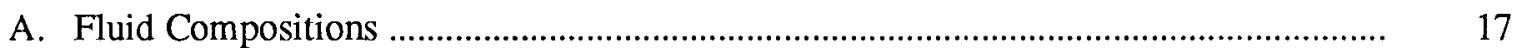

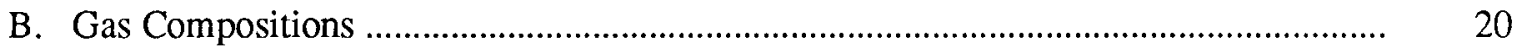

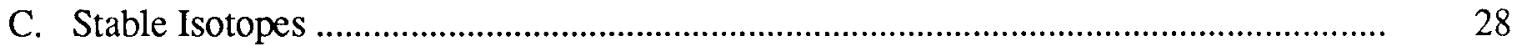

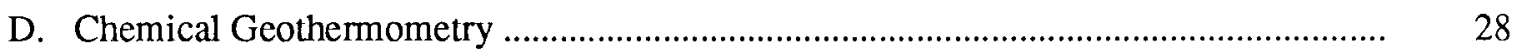

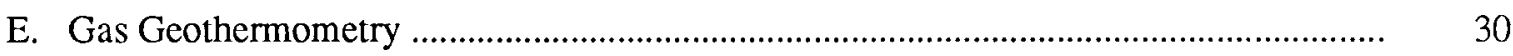

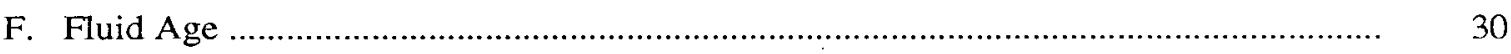

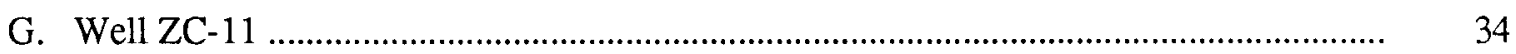

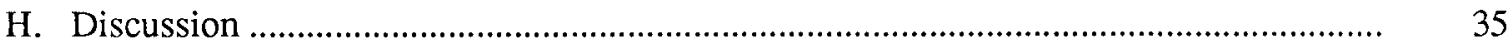

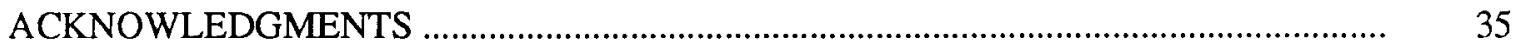

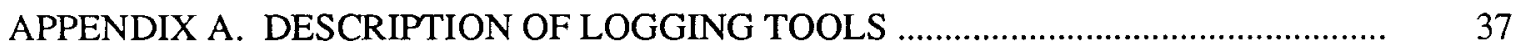

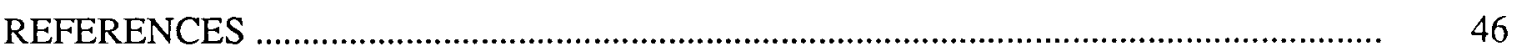




\section{FIGURES}

Fig. $i . \quad$ Location map of geothermal wells in the Zunil geothermal prospect......................iii

Fig. ii. Mapa de locacion de los pozos en el potencial geotérmico de Zunil.....................xvii

Fig. 1a. Three-dimensional block diagram of Zunil area.............................................. 2

Fig. 1b. Temperature cross section, wells ZCQ-5, ZCQ-3, and ZCQ-1.......................... 3

Fig. 1c. Temperature cross section, wells ZCQ-6, ZCQ-3, ZCQ-4, and ZCQ-2 ................4

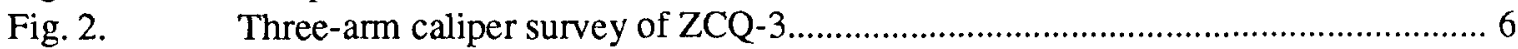

Fig. 3. Temperature surveys of ZCQ-3 ................................................................. 7

Fig. 4. STP results for well ZCQ-3, well shut-in after flowing

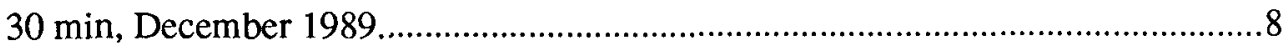

Fig. 5. STP results for ZCQ-3 , well flowing with bypass valve open.......................... 9

Fig. 6. Caliper survey of well ZCQ-4, December 1989.............................................11

Fig. 7. STP $\log \# 1$ in well ZCQ-4, December 11, 1989 (log-in) well shut in...................12

Fig. 8. $\quad$ STP $\log \# 2$ in well ZCQ-4, December 11, 1989 (log-out) ................................13

Fig. 9. STP $\log \# 3$ in well ZCQ-4, December 11, 1989 (log-in) ...................................14

Fig. 10. STP $\log \# 4$ in well ZCQ-4, December 11, 1989 (log-out) Flowing well................15

Fig. 11. Temperature data collected in well ZCQ-4 ...................................................16

Fig. 12. Observed temperatures in ZCQ-5, November 1989 during static conditions.........18

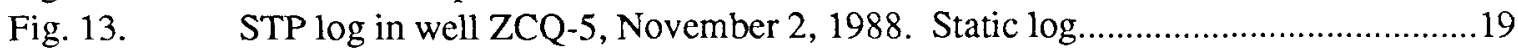

Fig. 14. Measured temperatures in well ZCQ-6, November 1988...................................21

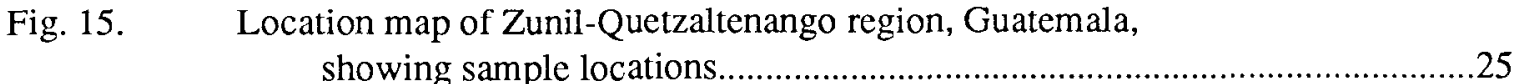

Fig. 16. Boron versus chloride for reservoir fluids, hot springs, and average values of the cold waters sampled...................................................26

Fig. 17. Bromide versus chloride for reservoir fluids and hot springs

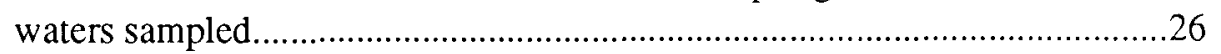

Fig. 18. Lithium versus chloride for reservoir fluids, hot springs,

Fig. 19. Cesium versus chloride for reservoir fluids, hot springs,

Fig. 20. Map showing $\mathrm{CO}_{2} / \mathrm{H}_{2} \mathrm{~S}$ for wells and fumaroles in the ZunilQuetzaltenango region, Guatemala..............................................................29

Fig. 21. Plot of $\delta D$ versus $\delta^{18} \mathrm{O}$ for thermal and nonthermal waters

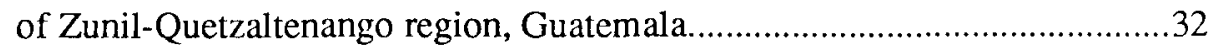

Fig. 22. Plot of tritium versus chloride for thermal and nonthermal waters of Zunil-Quetzaltenango region, Guatemala.....................................33

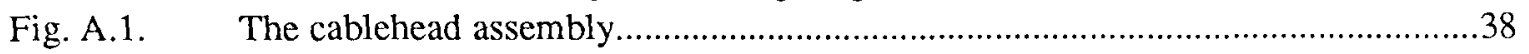

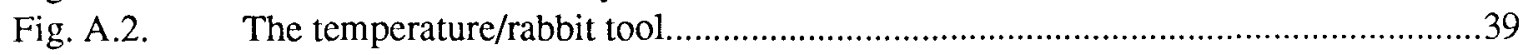

Fig. A.3. Schematic diagram of the Los Alamos fluid sampler used................................41 during this investigation.

Fig. A.4. The gas extraction system used in operations at the Zunil ...............................42 geothermal field, Guatemala.

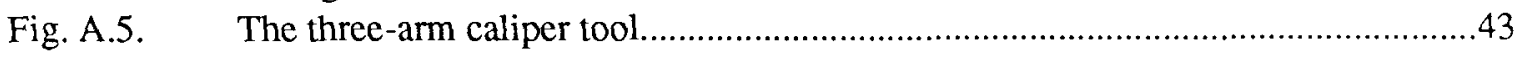

Fig. A.6. The spinner/temperature/pressure tool.............................................................46 


\section{TABLES}

Table I. Field Data for All Samples Collected in the Zunil-Quetzaltenango

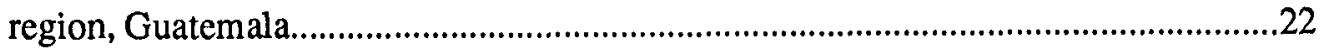

Table II. Major Element Chemistry for Wells, Hot/Cold Springs, and

Fumaroles in the Zunil-Quetzaltenango Region, Guatemala.....................................23

Table III. Trace Element Chemistry of Wells, Hot/Cold Springs, and

Fumaroles in the Zunil-Quetzaltenango Region, Guatemala

Table IV. Gas Analyses of Well and Fumarole Samples, Zunil, Guatemala.

.29

Table V. Isotope Data for Geothermal Wells, Hot/Cold Springs, and

Fumaroles in Zunil, Quetzaltenango Region, Guatemala. . .31

Table VI. Calculated "Reservoir" Temperatures Based on Several Chemical

Geothermometers

Table VII. Calculated "Reservoir" Temperatures Based on Gas Geothermometers 33 


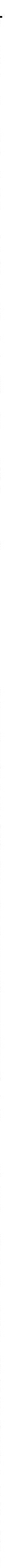




\section{EXECUTIVE SUMMARY}

The Zunil geothermal prospect has been the subject of investigation by the electric utility of Guatemala (Instituto Nacional de Electrificación, or INDE) for the last 15 years. The initial stages of the investigation were supported by the Japan International Cooperation Agency (JICA) and Electroconsult (ELC) of Italy. During the initial stages a number of small-diameter holes were drilled (in the mid-1970s) to quantify the resource. These holes led to the drilling of six deep large-diameter exploration wells (numbered ZCQ-1 through ZCQ-6) to confirm the reservoir existence (Fig. $i$ ). This drilling was performed in 1980 and 1981. Testing and evaluation of these wells were performed from 1981 until 1986.

In 1987, INDE, using funding provided by Banco Interamericano de Desarrollo (BID), funded Cordón y Mérida Ing., MK-Ferguson, and MK-Engineers, Inc. to develop and engineer a 15-MW plant based on existing or possible new wells. Two reports have been published to date that summarize the status of this work (MK-Ferguson Co. 1988, 1989).

In 1988, Los Alamos National Laboratory (LANL), as part of its Central American Energy and Resources Project, was commissioned to determine the condition of wells ZCQ-3 through ZCQ-6 by using the high-temperature tools developed for other geothermal programs (see Appendix A for a description of the tools). Additionally, LANL was to collect water/steam and gas samples downhole and on the surface to extend the geochemical information data base. Wells ZCQ-1 and ZCQ-2 were not investigated because they were unproductive, possibly from well damage during drilling.

Operational difficulties slowed the well logging activities initiated in the fall of 1988, making it impossible to complete the operation in one trip and necessitating a second trip in 1989. Between the two trips, numerous logs were executed that defined the condition of each well. The thermodynamic condition of the flowing wells was difficult to assess because the fluids in the wells did not reach a state of thermal equilibrium during the entire well logging program. The wells had been shut in and therefore static for several years. During the running of a number of fluid spinner/temperature/pressure (STP) logs in two 
flowing wells, it became evident that the liquid level, and thus the liquid/vapor interface, continued to move down the flowing well. A stable thermal equilibrium condition could not be achieved.

Fluid samples were collected in wells ZCQ-3, ZCQ-4, and ZCQ-5 from depths of 670, 775, and $900 \mathrm{~m}$, respectively. Weirbox samples were collected from wells ZCQ-3, ZCQ-4, ZCQ-6, and ZC-11 (a slimhole direct-use well). Gas samples were collected from numerous wells and fumaroles. Additional fluid samples were collected in the Zunil-Quetzaltenango region to provide further information on recharge, mixing, dilution, and age of the reservoir water. Results from the downhole fluid sample chemistry analysis did indicate that the Zunil reservoir is geochemically inhomogeneous. Stable isotope data indicate that recharge to the field is from the northeast volcanic area, and tritium data indicate that the reservoir water may be only 500 to 700 years old. Previous reports on the Zunil field appear in Fournier $e t$ al. (1982), Giggenbach (1986, 1988), Adams et al (1990), MK-Ferguson Co. (1988, 1989), and others. 


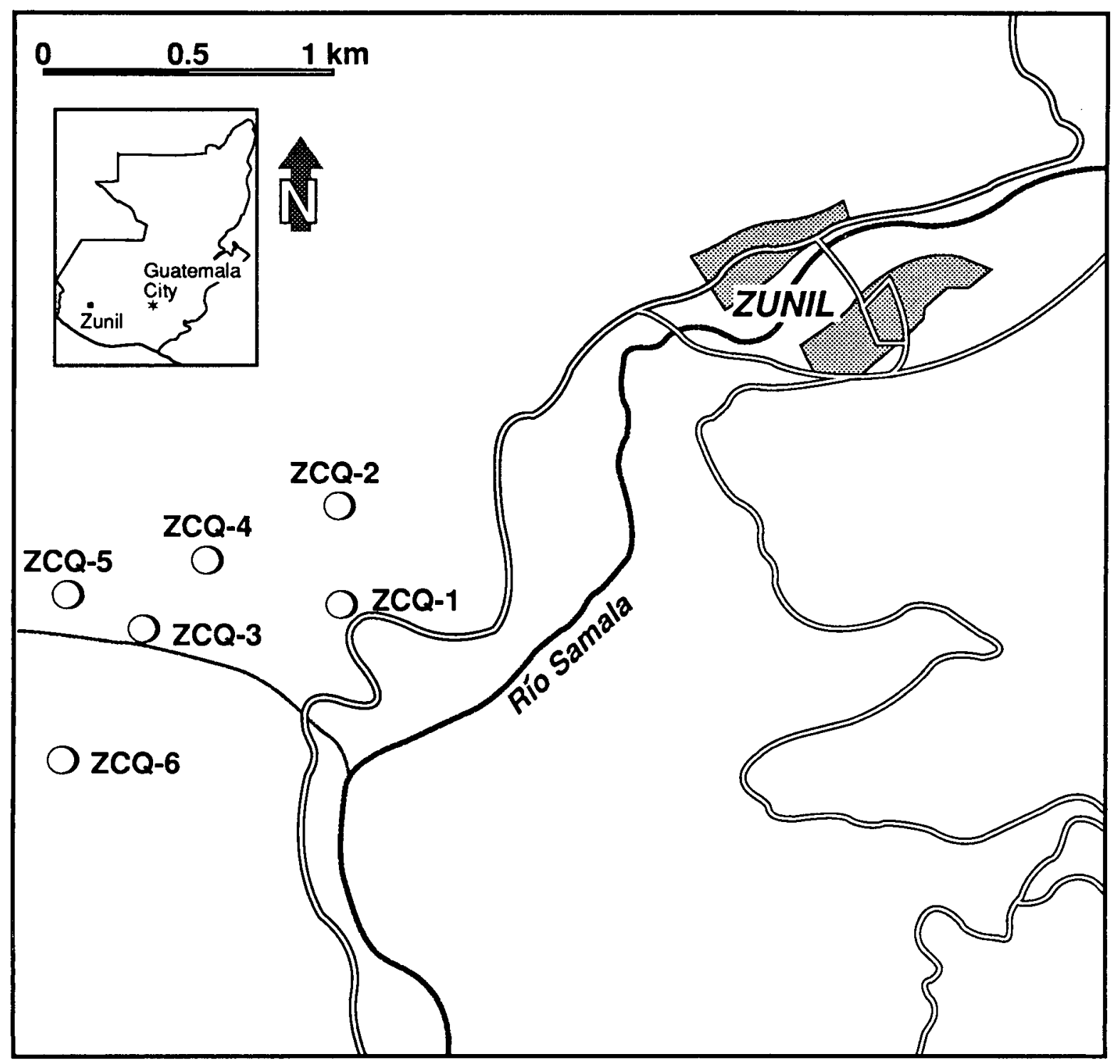

Fig. i. Location map of geothermal wells in the Zunil geothermal prospect. 


\section{RESUMEN EJECUTIVO}

El potencial geotérmico de Zunil ha sido objeto de investigación por la compañia eléctrica de Guatemala (Instituto Nacional de Electrificación, o INDE) durante los últimos 15 años. Las etapas iniciales de investigación recibieron el respaldo de la compañía japonesa "Japan International Cooperation Agency" (JICA) y la compañía italiana "Electroconsult" (ELC). Al comienzo de la investigación, un número de pozos de pequeños diámetros fueron perforados (a mediados de la década de los 70) para determinar la cantidad de los recursos geotérmicos existente. Estos pozos fueron los precursores de la perforacíon de seis pozos exploratorios profundos de gran diámetro (identificados ZCQ-1 al ZCQ-6) para confirmar la existencia del depósito (Figura ii). Esta perforación se llevó a cabo durante los años 1980 y 1981. Los análisis y evaluaciones de estos pozos se efectuaron durante los años 1981 y 1986.

Durante el año siguiente, el INDE, usando fondos suministrados por el Banco Interamericano de Desarrollo (BID) financió a Cordón y Mérida Ing., MK-Ferguson, y MK-Engineers, Inc., para desarrollar y construir una planta de $15 \mathrm{MW}$, basándose en pozos existentes y los potenciales. A la fecha se han publicado dos reportes, los cuales resumen el estado de este trabajo (MK-Ferguson Co. 1988, 1989).

Durante 1988, Los Alamos National Laboratory (LANL), como parte de su Proyecto Centroamericano de Energía y Recursos Naturales, fue comisionado a determinar las condiciones de los pozos ZCQ-3 al ZCQ-6, utilizando los instrumentos de medición que había desarrollado para otros programas geotérmicos (para descripción de los instrumentos, véase Anexo A). Además, LANL debía colectar muestras del agua, vapor y gas del subsuelo y la superficie de los pozos para extender la información geoquímica a la base de datos. Los pozos ZCQ-1 y ZCQ-2 no se investigaron por no ser productivos, posiblemente debido a daños causados a los pozos durante su perforación.

Dificultades operacionales atrasaron las actividades iniciadas en el registro cronológico de la perforación de pozos durante el otoño del año 1988, haciendo imposible terminar la operación en una sola visita, requiriéndose un segundo viaje en el año 1989. Entre los dos viajes, numerosos registros se llevaron 
a cabo, produciendo éstos resultados categóricos de las condiciones de cada pozo. Las condiciones del flujo de los pozos fue difícil de catalogar porque los fluidos en los pozos no alcanzaron un estado de equilibrio termal durante todo el período del programa analítico de pozo. Los pozos se cerraron y por lo tanto estuvieron inactivos por varios años. Durante varios de los registros de flujo/temperatura/presión (STP) de los pozos fluyentes, se hizo obvio que el nivel del líquido, a su vez el intercambio del líquido y vapor, causara movimiento continuo hacia abajo en el pozo fluyente. Condición de equilibrio termal no se pudo alcanzar.

Muestras del flujo se colectaron de los pozos ZCQ-2, ZCQ-4 y ZCQ-5, desde profundidades de 670, 775 y 900 metros, respectivamente. Muestras Weirbox se obtuvieron de los pozos ZCQ-3, ZCQ-4, ZCQ-6 y ZC-11 (un pozo angosto de uso directo). Muestras de gas fueron colectadas de varios pozos y fumarolas. Muestras adicionales se colectaron en las región de Zunil y Quetzaltenango, proveyendo mayor información sobre recarga, mezcla, dilución y la era del depósito. Los resultados de las muestras fluidas de los análisis químicos del pozo abajo indicaron que la reserva de Zunil no es geoquímicamente homogénea. Los datos isotópicos estables indican que el recargo en el campo proviene desde el área volcánica noreste, y los datos de tritio indican que el depósito de agua puede existir desde hace ya 500 a 700 años. Reportes anteriores sobre el campo de Zunil aparecen en escritos de Fournier y otros (1982), Giggenbach (1986, 1988), Adams y otros (1990), MK-Ferguson Co., y otros. 


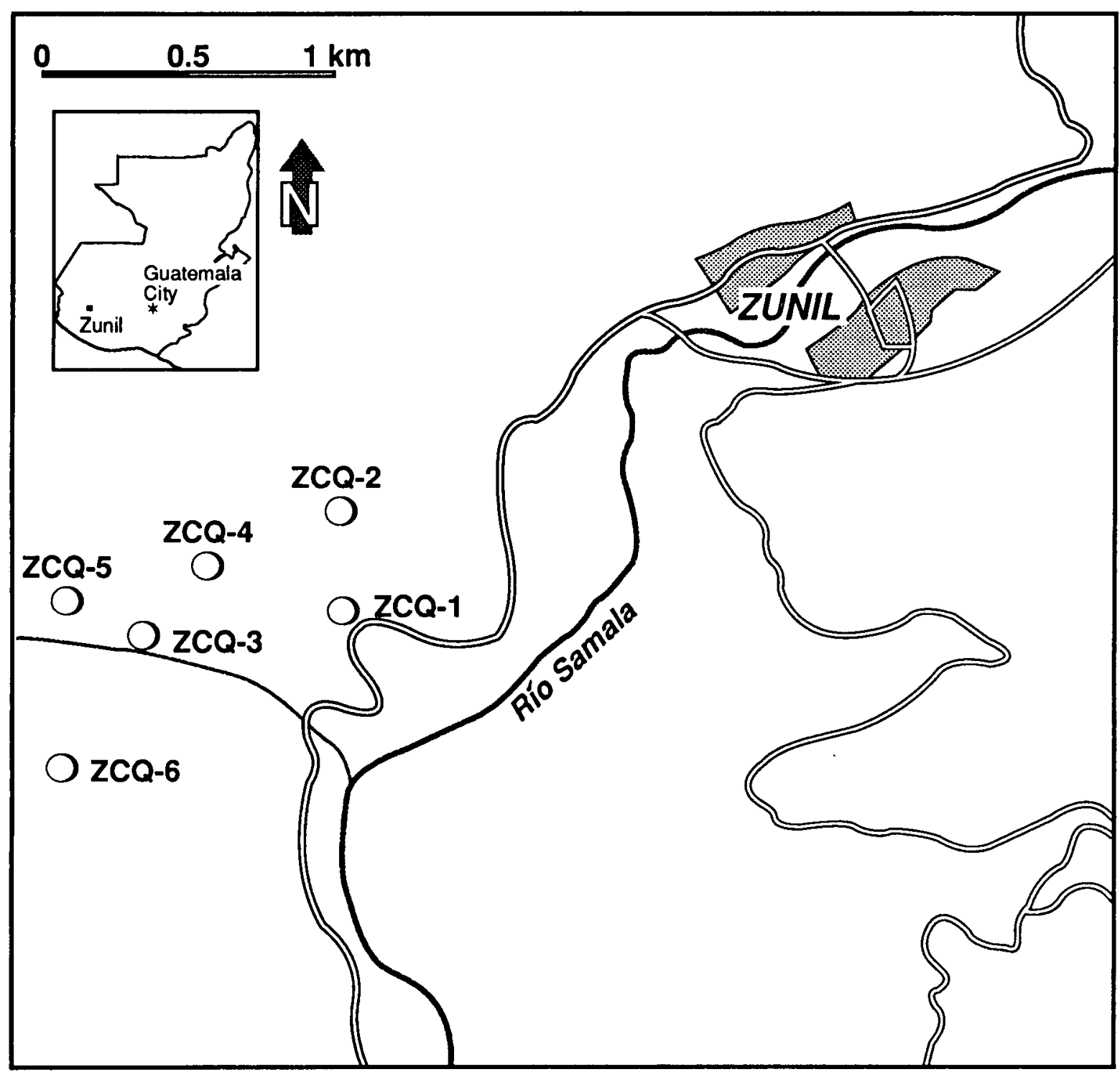

Fig. ii. Mapa de localización de pozos potenciales geotérmicos de Zunil. 


\title{
RESULTS OF INVESTIGATIONS AT THE ZUNIL \\ GEOTHERMAL FIELD, GUATEMALA: WELL LOGGING AND BRINE GEOCHEMISTRY
}

\author{
by \\ Andrew Adams, Bert Dennis, Ed Van Eeckhout, Fraser Goff, \\ Robert Lawton, P. E. Trujillo, Dale Counce, \\ Victor Medina, and J. Archuleta
}

\begin{abstract}
The well logging team from Los Alamos and its counterpart from Central America were tasked to investigate the condition of four producing geothermal wells in the Zunil Geothermal Field. The information obtained would be used to help evaluate the Zunil geothermal reservoir in terms of possible additional drilling and future power plant design. The field activities focused on downhole measurements in four production wells (ZCQ-3, ZCQ-4, ZCQ-5, and ZCQ-6). The teams took measurements of the wells in both static (shut-in) and flowing conditions, using the high-temperature well logging tools developed at Los Alamos National Laboratory.

Two well logging missions were conducted in the Zunil field. In October 1988 measurements were made in well ZCQ-3, ZCQ-5, and ZCQ-6. In December 1989 the second field operation logged ZCQ-4 and repeated logs in ZCQ-3. Both field operations included not only well logging but the collecting of numerous fluid samples from both thermal and nonthermal waters.
\end{abstract}

\section{INTRODUCTION}

The Zunil geothermal field, as noted in Fig. $i$, is 120 miles northwest of Guatemala City. Preliminary work there resulted in the drilling of 6 wells in 1980 and 1981. Of the six, two were damaged and unproductive (wells ZCQ-1 and ZCQ-2), two produced superheated steam (wells ZCQ-4 and ZCQ-5), and two are currently commercially productive at acceptable wellhead pressures (wells ZCQ-3 and 
ZCQ-6). The location of these wells relative to a schematic of the structure is shown in Fig. 1a. Figures $1 \mathrm{~b}$ and $1 \mathrm{c}$ show the temperature schematics from early measurements.

Sections II and III describe the logging performed and the geochemical results obtained during our efforts.

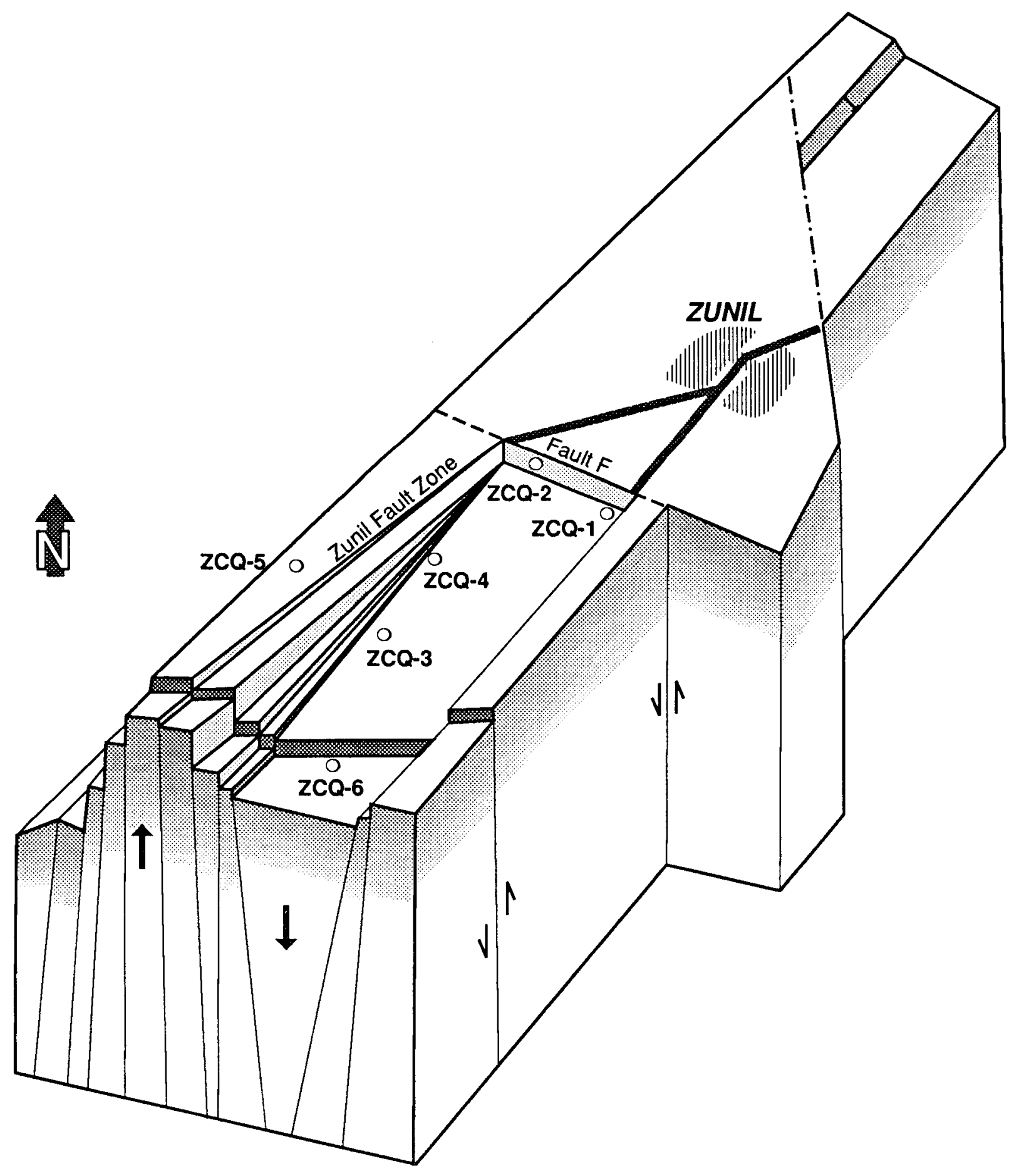

Fig. 1a. Three-dimensional block diagram of Zunil area. 


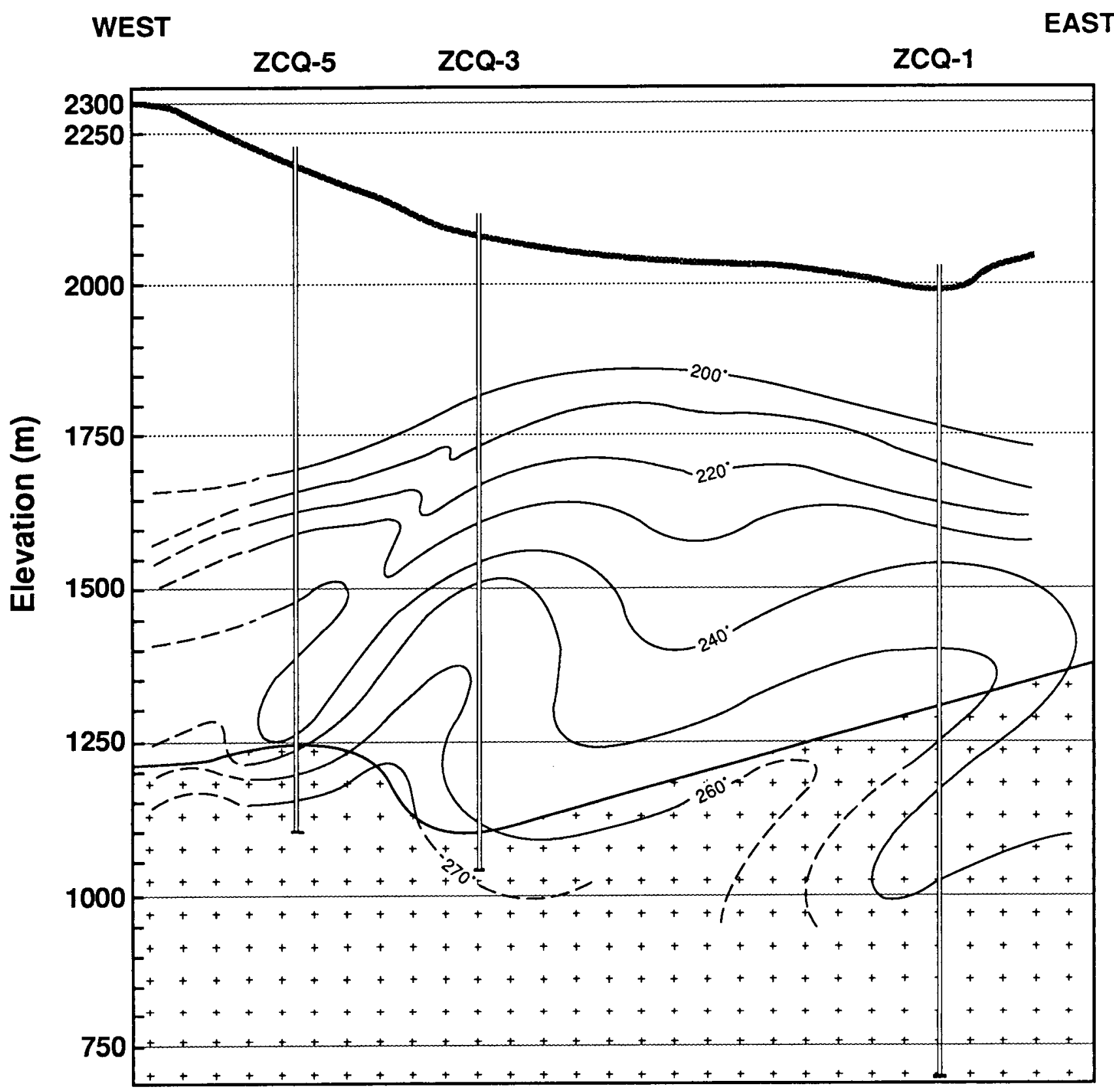

Fig. 1b. Temperature cross section, wells ZCQ-5, ZCQ-3, and ZCQ-1 (MK-Ferguson 1988). 


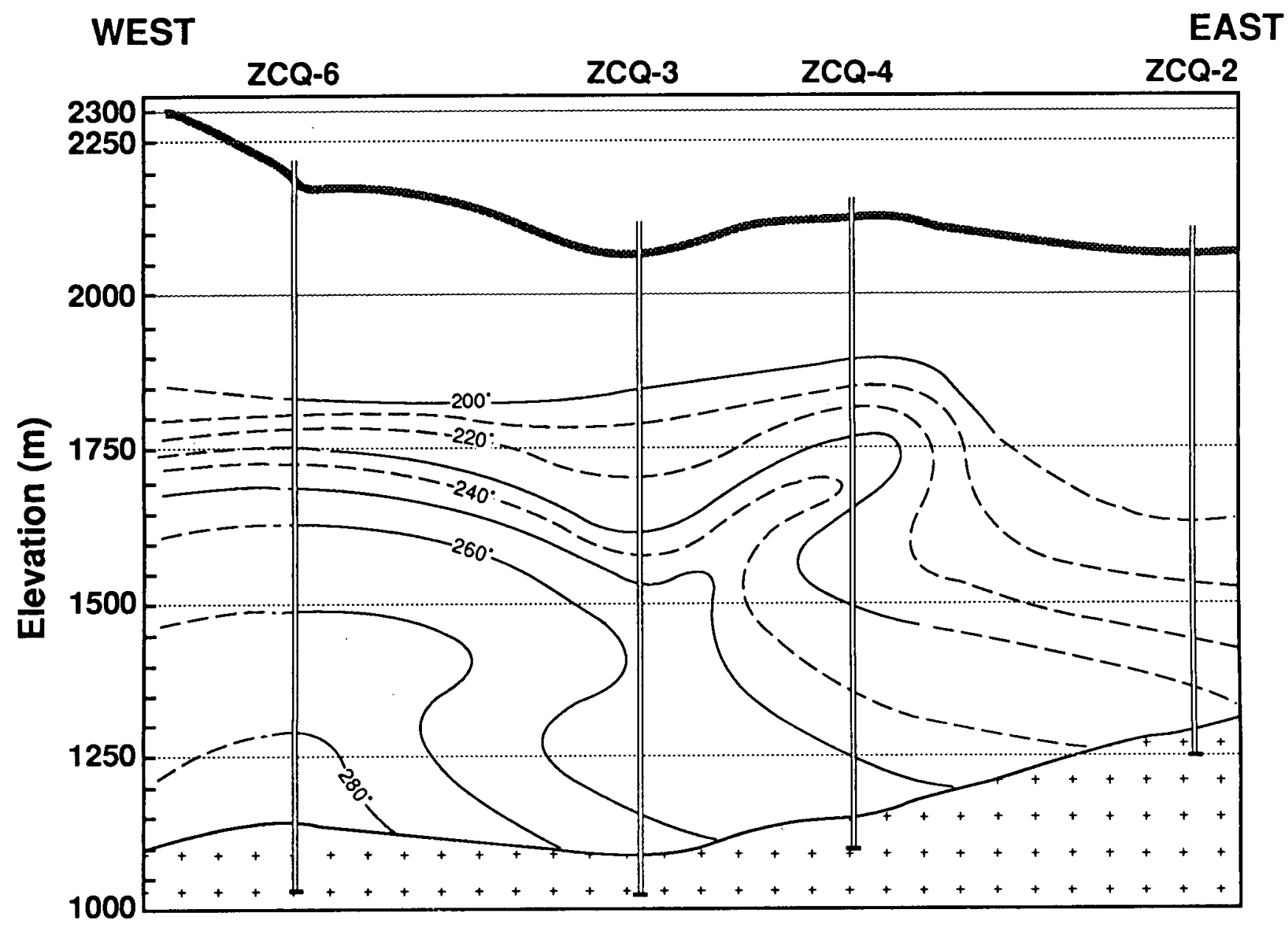

Fig. 1c. Temperature cross section, wells ZCQ-6, ZCQ-3, ZCQ-4, and ZCQ-2.

\section{WELL LOGGING OPERATIONS}

A. ZCQ-3

Well ZCQ-3 was drilled to a depth of $1040 \mathrm{~m}$ and completed with $95 / 8$-in. casing to $570 \mathrm{~m}$. A $75 / 8$-in. slotted liner was hung from $560 \mathrm{~m}$ to a depth of $1030 \mathrm{~m}$. Earlier surveys had reported the maximum temperature at $260^{\circ} \mathrm{C}$ near the bottom of the well and liquid level at $600 \mathrm{~m}$. Wellhead pressure with the well shut in was $668 \mathrm{psi}$, which dropped to $150 \mathrm{psi}$ about 1 hour after the system was opened to flow.

The first attempts to run the well logging tools in ZCQ-3 in October 1988 encountered several problems. The slots in the liner were wider than dimensions typically used in Central America, and the tips 
on the three-arm caliper tool were not wide enough to bridge the slots. The teams ran the caliper log in the casing only to avoid damage to the caliper arms. Also, pressurized air was necessary to lift this well. However, the lack of working equipment (compressor) during the first field operation limited logging operations to static well conditions.

A shut-in temperature/rabbit survey was made to a depth of $1030 \mathrm{~m}$. The maximum temperature measured $260^{\circ} \mathrm{C}$ at about $670 \mathrm{~m}$. This temperature run was followed by a fluid sample taken at $671 \mathrm{~m}$. Then the three-arm caliper was run from $557 \mathrm{~m}$ to the surface and showed no chemical deposits and very little, if any, scaling.

For the second phase of the Zunil field operations (December 1989) we modified the tips on the caliper tool to allow completion of the caliper log through the slotted liner from $1010 \mathrm{~m}$ to $500 \mathrm{~m}$. Figure 2 shows data from the $1988 \mathrm{log}$ and the $1989 \mathrm{log}$. When a temperature/rabbit survey of the well was repeated, the collar locator in the temperature tool found the slotted liner at $568 \mathrm{~m}$, establishing agreement with the caliper log. Figure 3 summarizes data from all temperature surveys made in ZCQ-3.

Data of more interest resulted from a sequence of STP measurements of ZCQ-3. The STP tool was rigged up and set in the pressure lock. While the well was shut in, pressurized air lifted the well. Then flow from the well was allowed through the vent lines to the mufflers until a significant flow rate was established (about $30 \mathrm{~min}$ ). The well was then shut in and the first STP survey was run from the surface to $1005 \mathrm{~m}$. The liquid/vapor interface appeared to be between 460 and $500 \mathrm{~m}$ although the well was in a transient condition (Fig. 4). After this shut-in log, we made two additional STP surveys with the well flowing. The first flowing $\log$ ran from $1005 \mathrm{~m}$ up to $580 \mathrm{~m}$ with the bypass valve open to full flow. It is quite obvious from the pressure and spinner data that the liquid/vapor interface had moved below $1005 \mathrm{~m}$ during the third $\log$ (Fig. 5). The entire wellbore contained two-phase flow and was still in a highly transient state. It is probable that in a relatively short time, only two-phase fluid will intersect this well. The drop in fluid temperature and pressure, measured during the third $\log$, confirms the absence of liquid in this region of the well.

\section{B. ZCQ-4}

Well ZCQ-4 was a production well drilled to a depth of $1025 \mathrm{~m}$. The $75 / 8$-in. slotted liner was hung in the $95 / 8$-in. casing at $420 \mathrm{~m}$ and extended to a depth of $1020 \mathrm{~m}$. The reported water level with the well shut-in was about $650 \mathrm{~m}$. Wellhead pressure was 573 psi with the wellhead valves closed and dropped to 110 psi under flowing conditions. Maximum fluid temperature was $240^{\circ} \mathrm{C}$ near the bottom of the well.

We ran the three-arm caliper tool in the well from $1000 \mathrm{~m}$ to the surface. The slotted liner section of the wellbore from $1000 \mathrm{~m}$ up to $420 \mathrm{~m}$ showed evidence of some chemical build-up inside the liner 


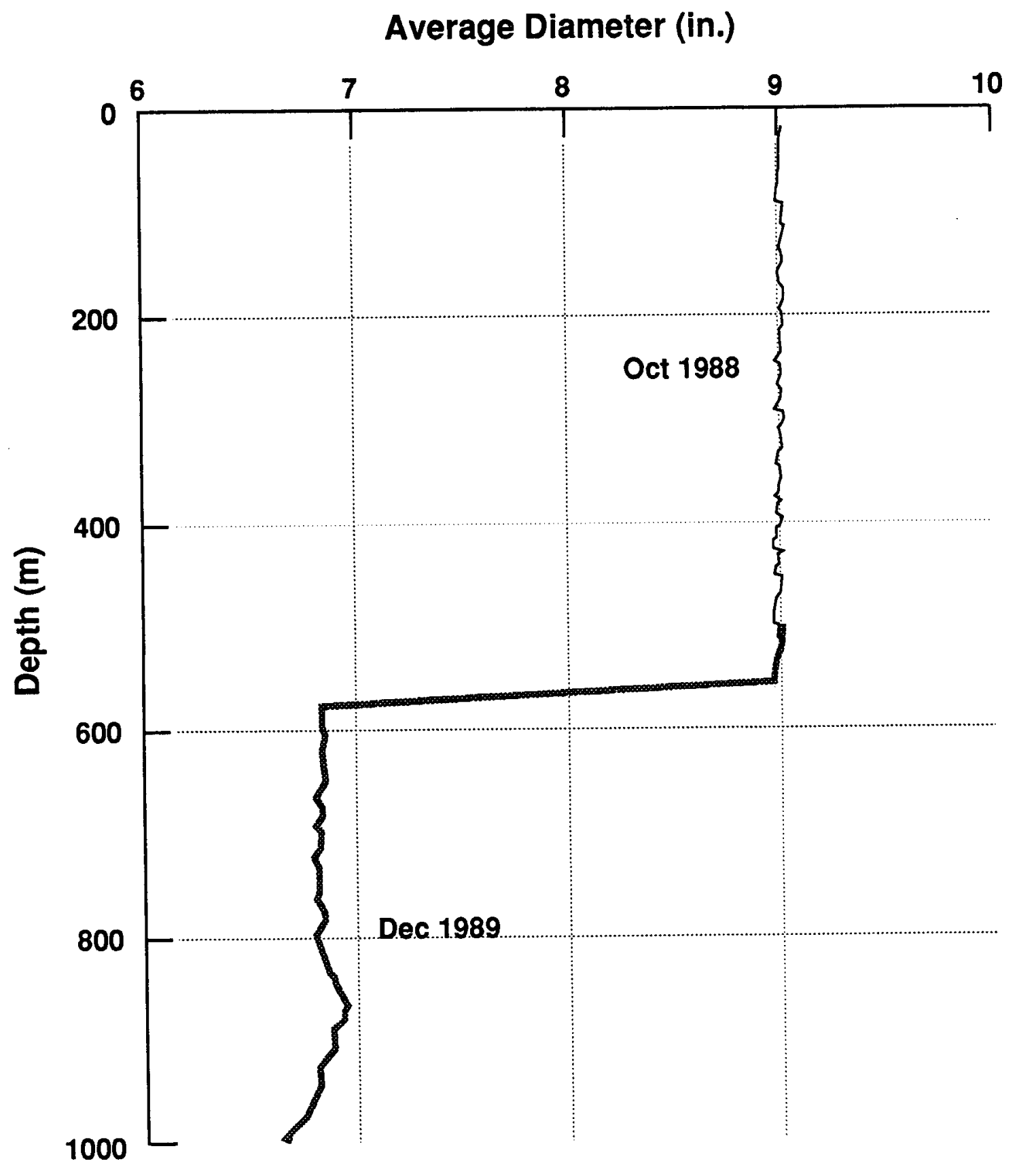

Fig. 2. Three-arm caliper survey of ZCQ-3. 


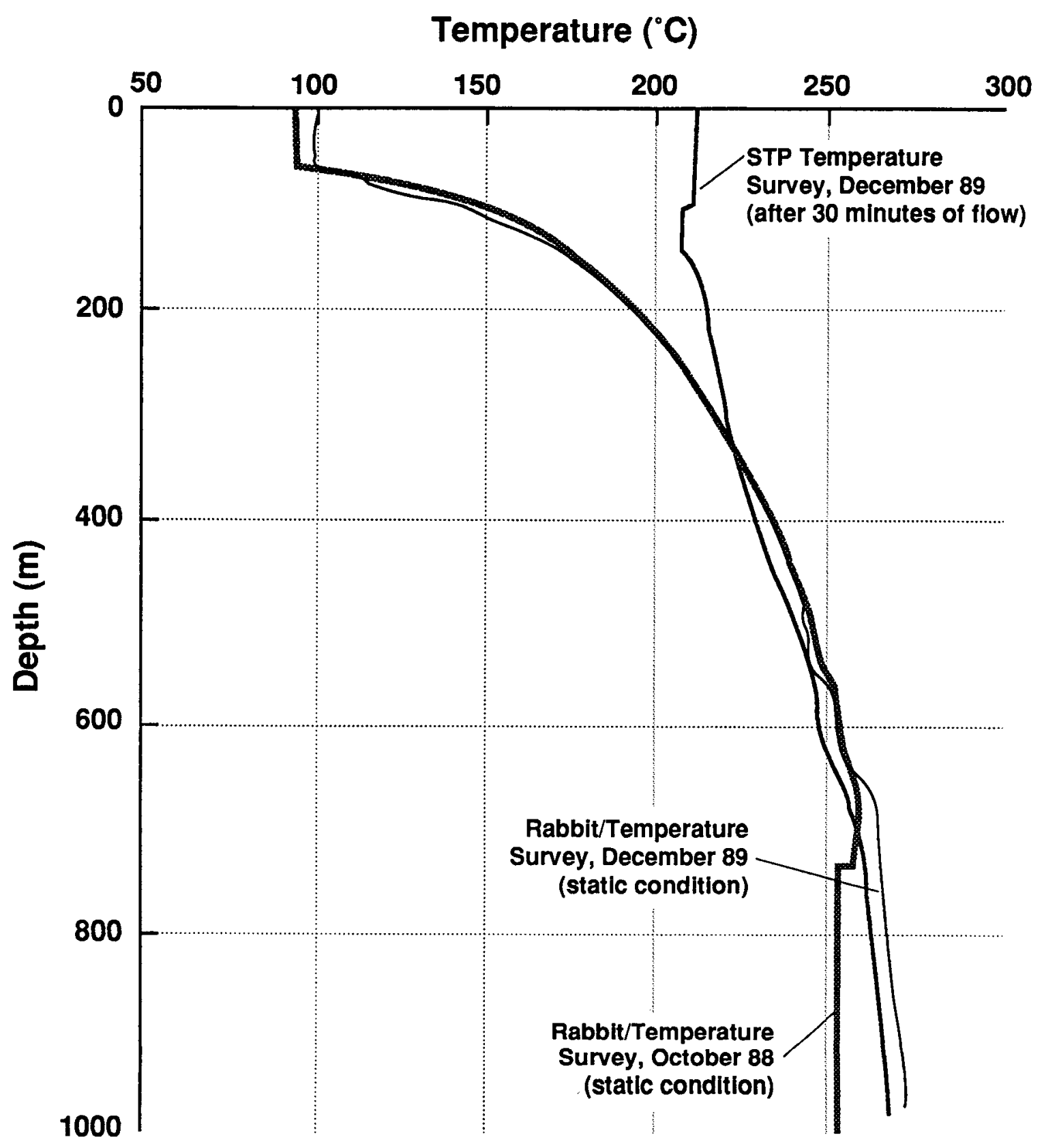

Fig. 3. Temperature surveys of ZCQ-3. 


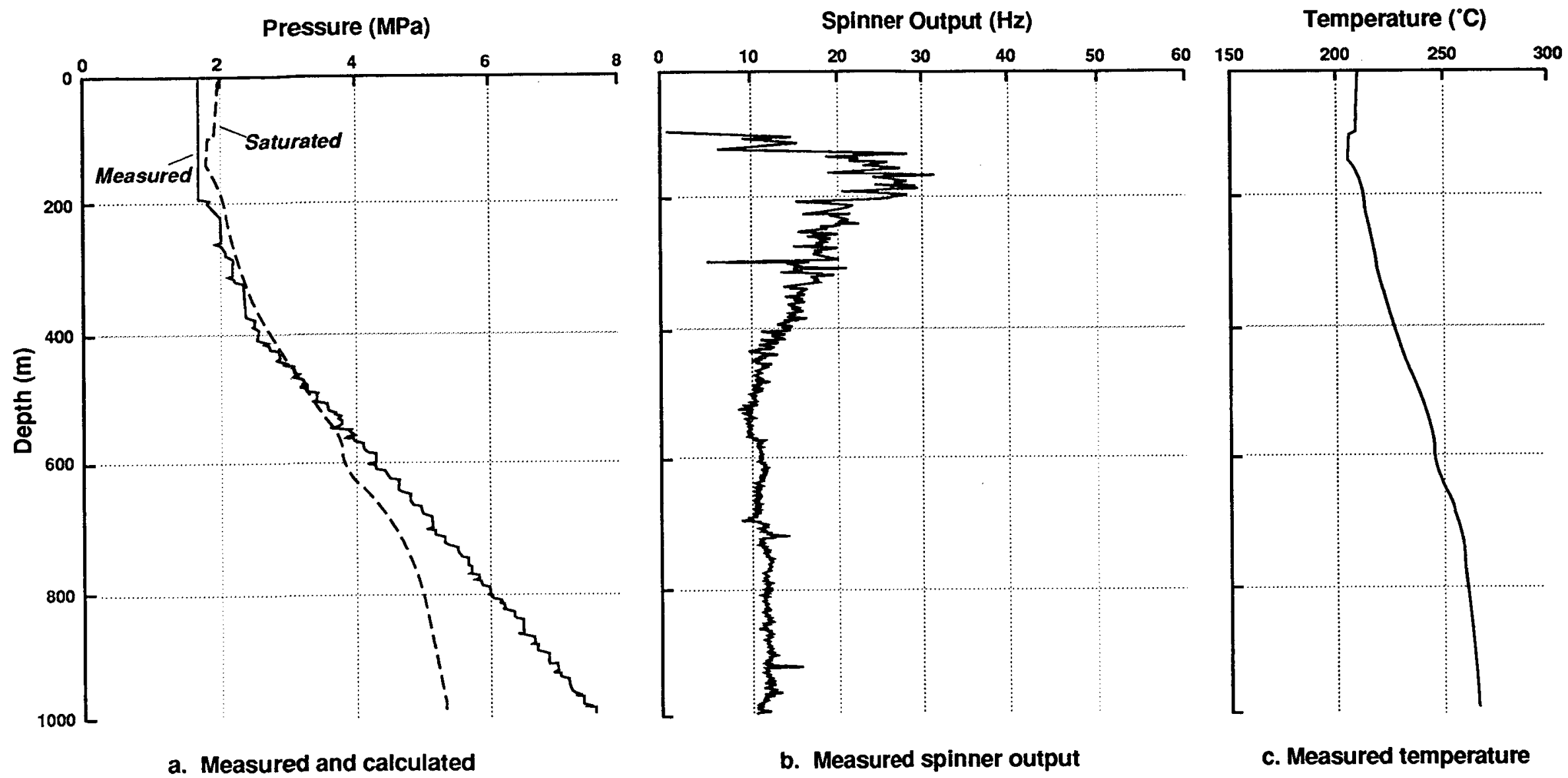

Fig. 4. STP results for well ZCQ-3, well shut-in after flowing 30 min, December 1989. 


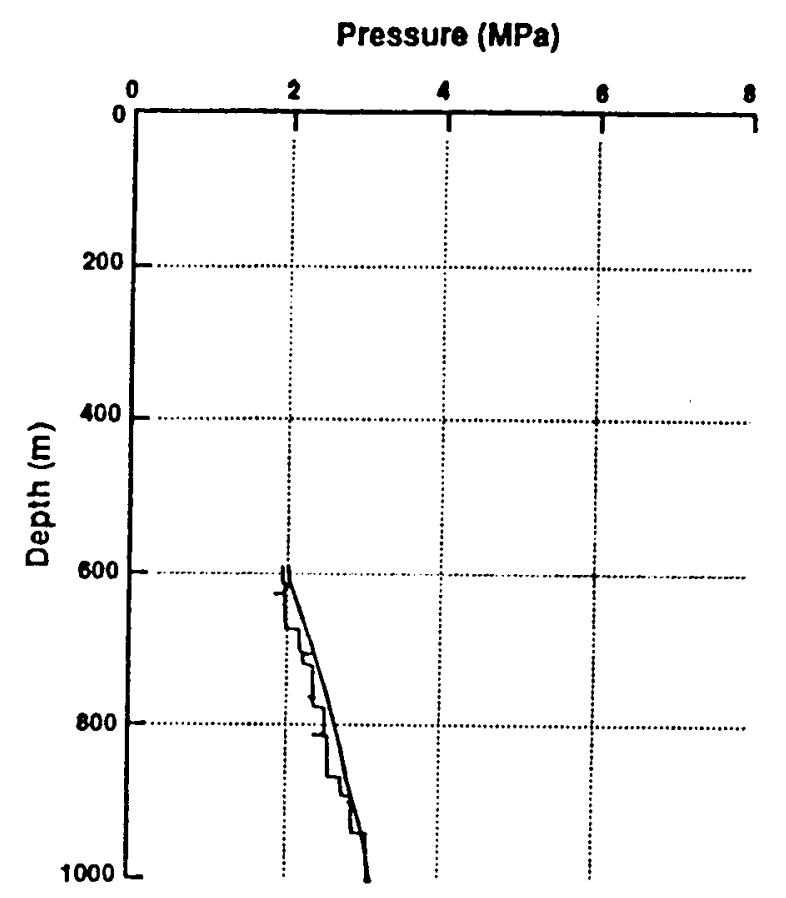

a. Measured and calculated saiuration pressures

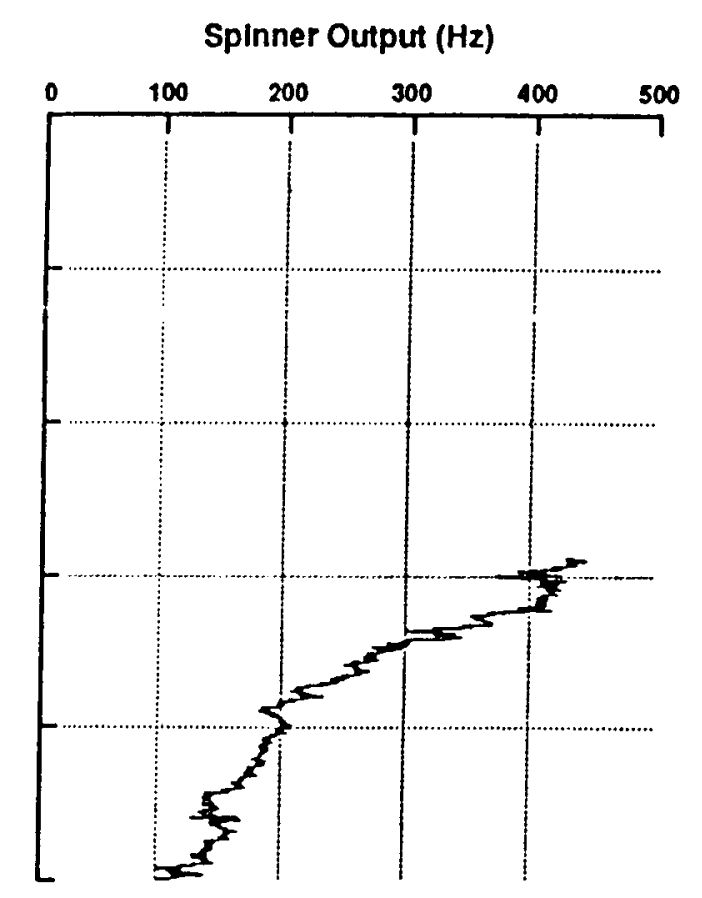

b. Measured spinner output
Temperature $\left({ }^{\circ} \mathrm{C}\right)$

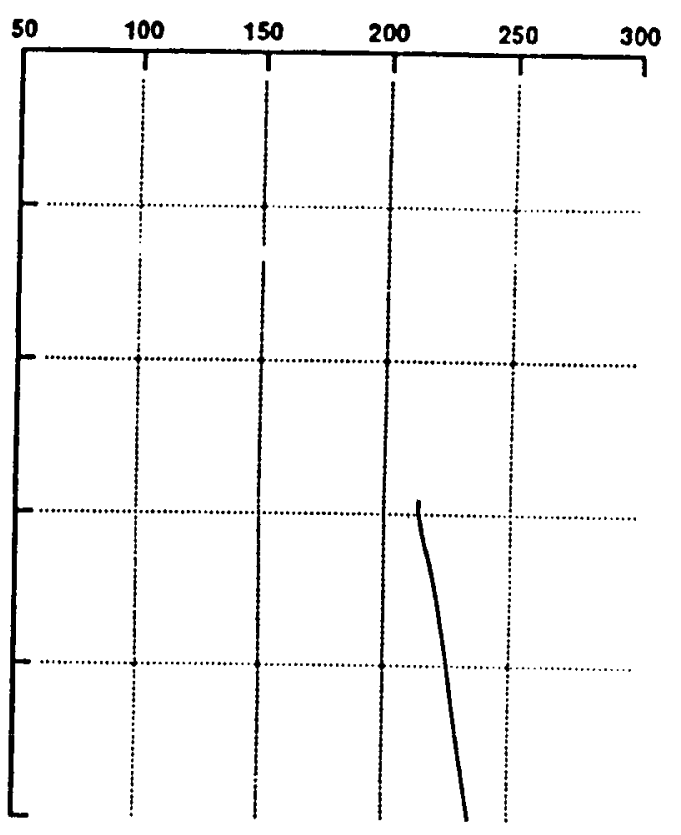

c. Measured temperature

Fig. 5. STP results for well ZCQ-3, well flowing with bypass valve open to full flow. 
(Fig. 6). There was also evidence of some slight chemical build-up in the $95 / 8$-in. casing from the liner hanger up to about $200 \mathrm{~m}$. The caliper log was followed by a fluid sample taken at $900 \mathrm{~m}$.

The STP tool was rigged up to run a series of logs in this well. The first survey ran from the surface to $1000 \mathrm{~m}$ with the well shut-in after the well was allowed to flow for an undetermined period of time. The STP data from this $\log$ (Fig. 7) show that the liquid level was detected at $470 \mathrm{~m}$. The tool velocity from the surface to $650 \mathrm{~m}$ was $35 \mathrm{~m} / \mathrm{min}$. Increasing the velocity to $50 \mathrm{~m} / \mathrm{min}$ from 650 to $1000 \mathrm{~m}$ resulted in the step increase in the spinner output at $650 \mathrm{~m}$. The spinner data taken from 870 to $1000 \mathrm{~m}$ indicate a circulation zone in which fluid entered the well below $1000 \mathrm{~m}$, flowed up the well, and exited at $870 \mathrm{~m}$.

The second STP survey was run from a depth of $1000 \mathrm{~m}$ up to $460 \mathrm{~m}$ with the wellhead bypass valve cracked open (1/8 of full flow). The resulting low flow allowed in the well provided some interesting results, notably that the circulation zone was noticeably diminished and the liquid/vapor interface moved down the well to about $515 \mathrm{~m}$ (Fig. 8). The data were essentially unchanged on the third STP survey (Fig. 9), which ran from about $1000 \mathrm{~m}$ to $460 \mathrm{~m}$ under conditions the same as those for the second $\log$.

Then the STP tool was retumed to the $1000 \mathrm{~m}$ depth and the wellhead bypass valve was opened to $33 \%$ of full flow. We recorded data from $1000 \mathrm{~m}$ to $200 \mathrm{~m}$ that showed the flowing conditions in a high transient state (Fig. 10). The measured pressure, higher than the saturation pressure from about $760 \mathrm{~m}$ to $1000 \mathrm{~m}$ (liquid region), showed that the liquid/vapor interface was rapidly moving down the well. The spinner output data showed fluid entering the well at about $920 \mathrm{~m}$. The pressure gradient, between $900 \mathrm{~m}$ and $1000 \mathrm{~m}$ during this $\log$, was $0.015 \mathrm{MPa} / \mathrm{m}$, which was 1.8 times a normal steady-state hydrostatic pressure gradient. Because well conditions were in a such a transient state, no thermodynamic analysis could be calculated. Figure 11 shows a comparison of the temperature data for the four STP logs. For the shut-in and very low flow rate conditions, the temperatures throughout the wellbore were essentially identical. For the larger flow rate (STP $\log 4$ ), the vapor or steam temperatures dropped as expected, although the temperatures in the liquid from $760 \mathrm{~m}$ to the bottom of the well remained the same. The drop in vapor temperatures may give some indication of the vapor quality of the two-phase fluid flow.

\section{C. $\mathrm{ZCQ}-5$}

Well ZCQ-5 was a nonproductive well with ambient pressure at the wellhead. ZCQ-5 was drilled to a depth of $1080 \mathrm{~m}$. The $95 / 8$-in. casing extended to a depth of $751 \mathrm{~m}$ and a $75 / 8$-in. slotted liner was hung from $737 \mathrm{~m}$ to $951 \mathrm{~m}$. The maximum reported temperature was about $260^{\circ} \mathrm{C}$ at the bottom of the well.

Because this well had no differential pressure at the wellhead and was nonproductive, the pressure lock and cable pack-off assembly were unnecessary. The fluid sampler was deployed to $775 \mathrm{~m}$, and the measured temperature of the borehole fluid at the sample depth was $260^{\circ} \mathrm{C}$. 


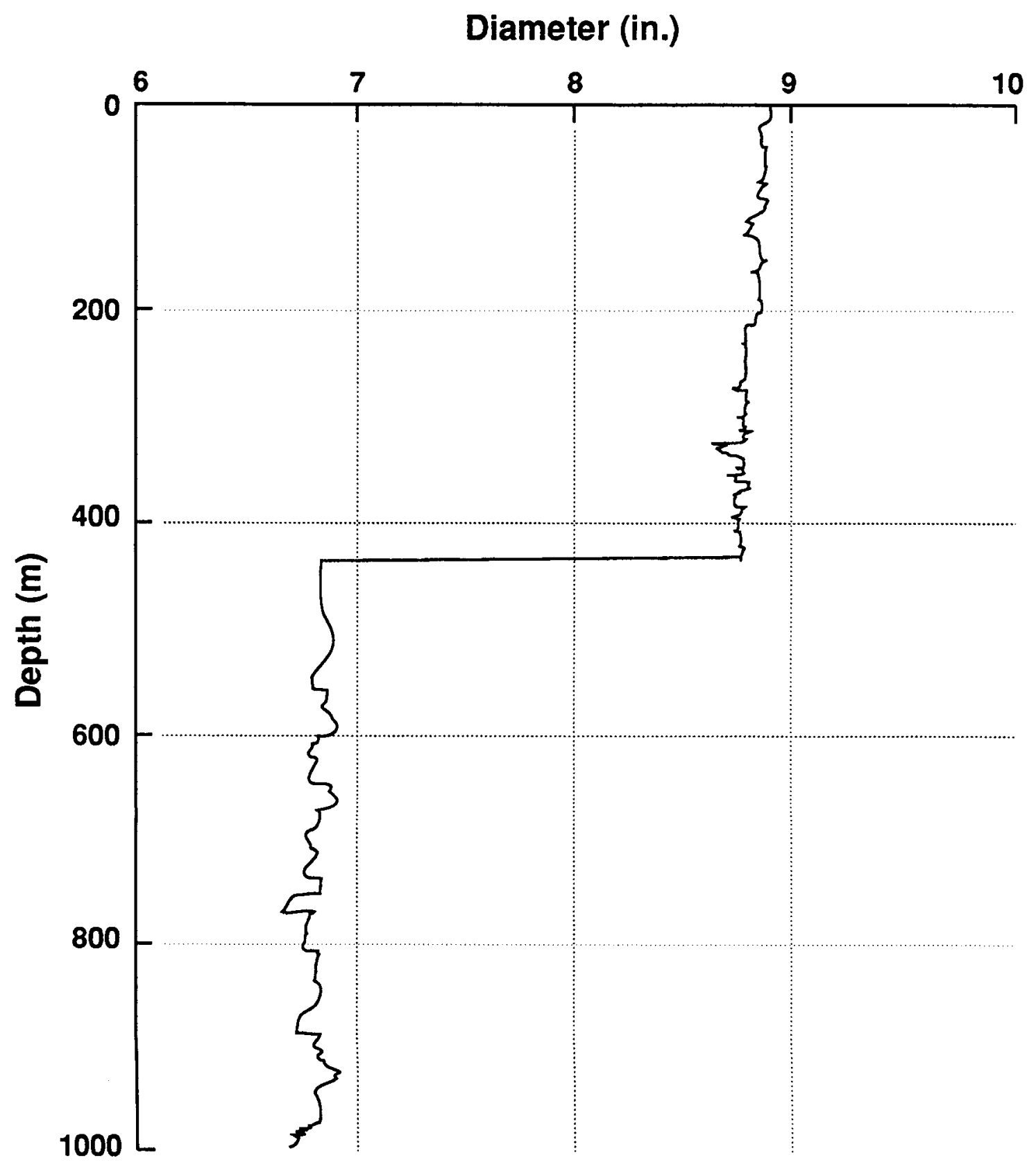

Fig. 6. Caliper survey of well ZCQ-4, December 1989. 
$\vec{N}$

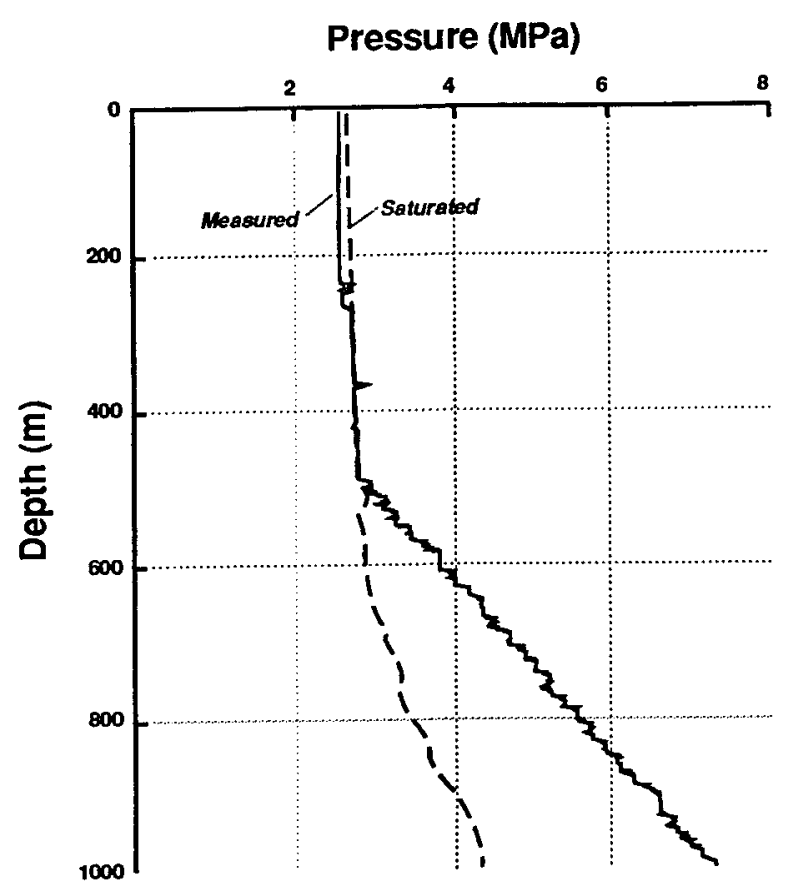

a. Measured and calculated saturation pressures

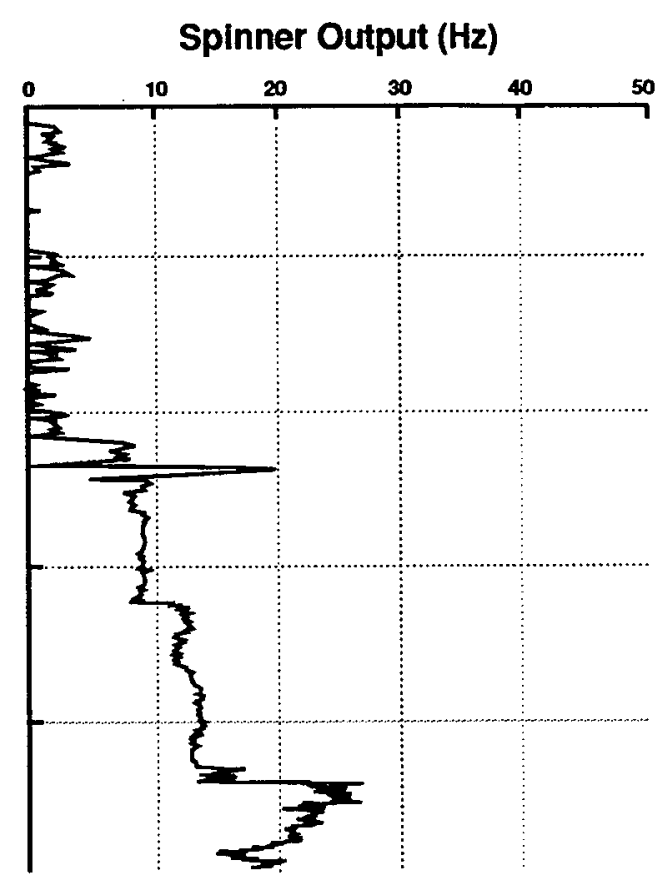

b. Measured spinner output

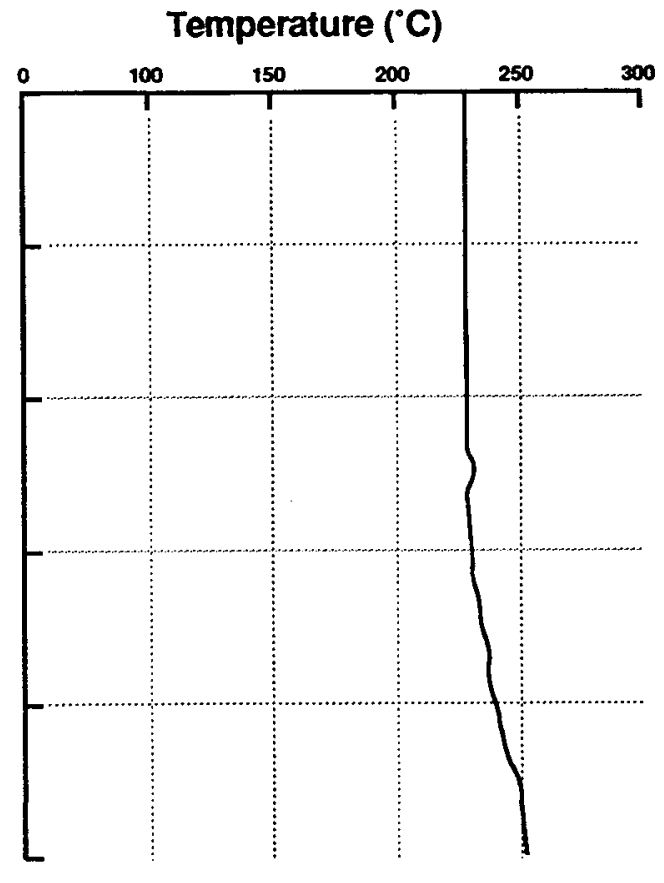

c. Measured temperature

Fig. 7. STP $\log \# 1$ in well ZCQ-4, December 11,1989 (log-in). Well shut in. 


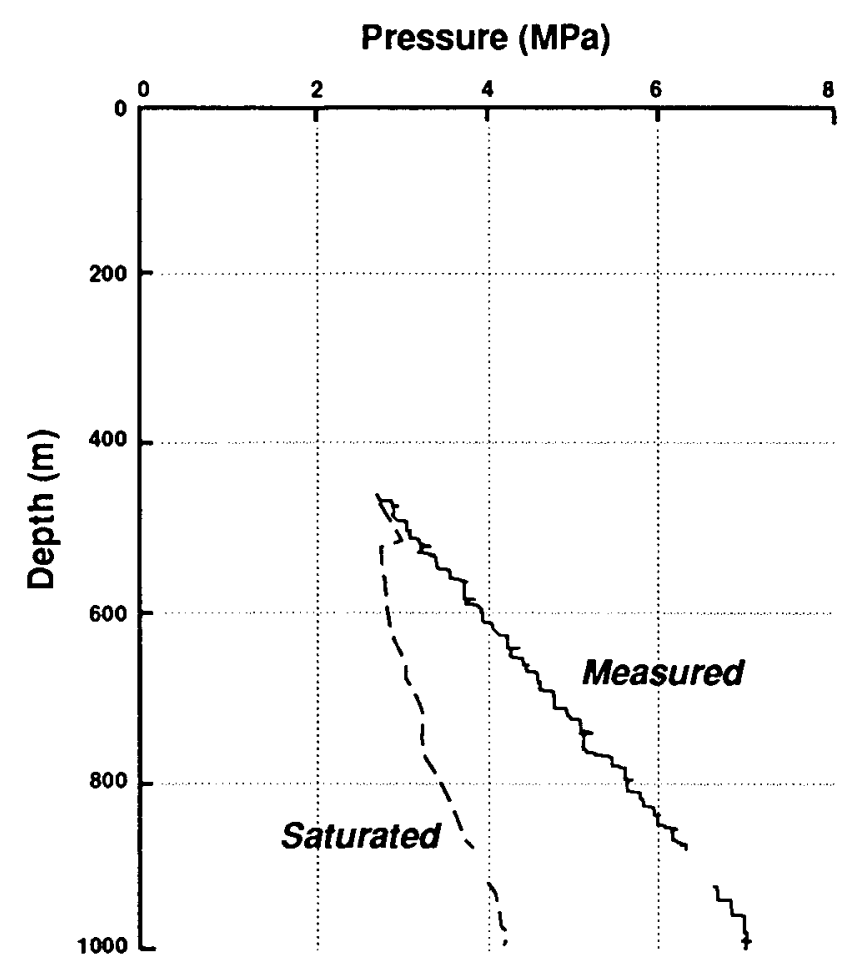

a. Measured and calculated saturation pressures

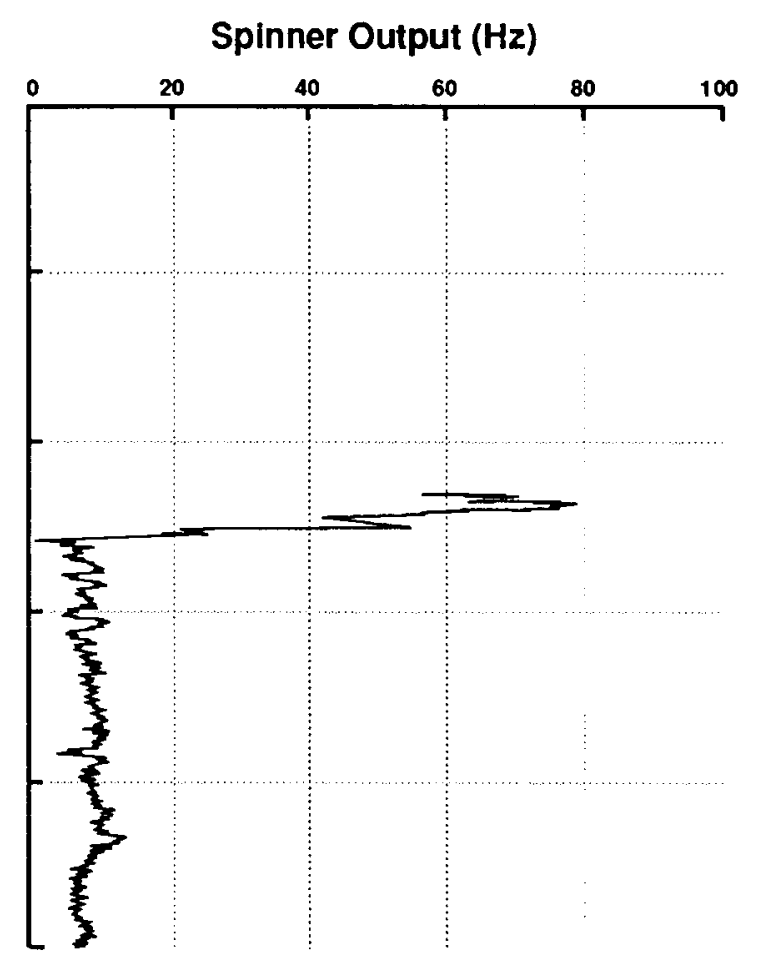

b. Measured spinner output

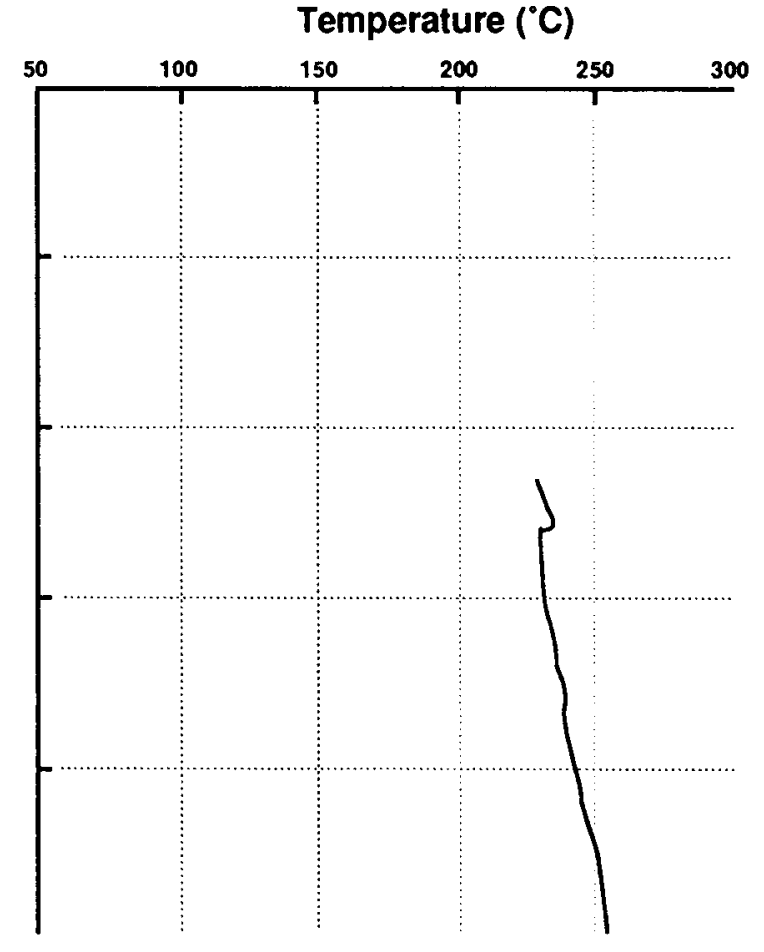

c. Measured temperature

Fig. 8. STP $\log \# 2$ in well ZCQ-4, December 11, 1989 (log-out). 


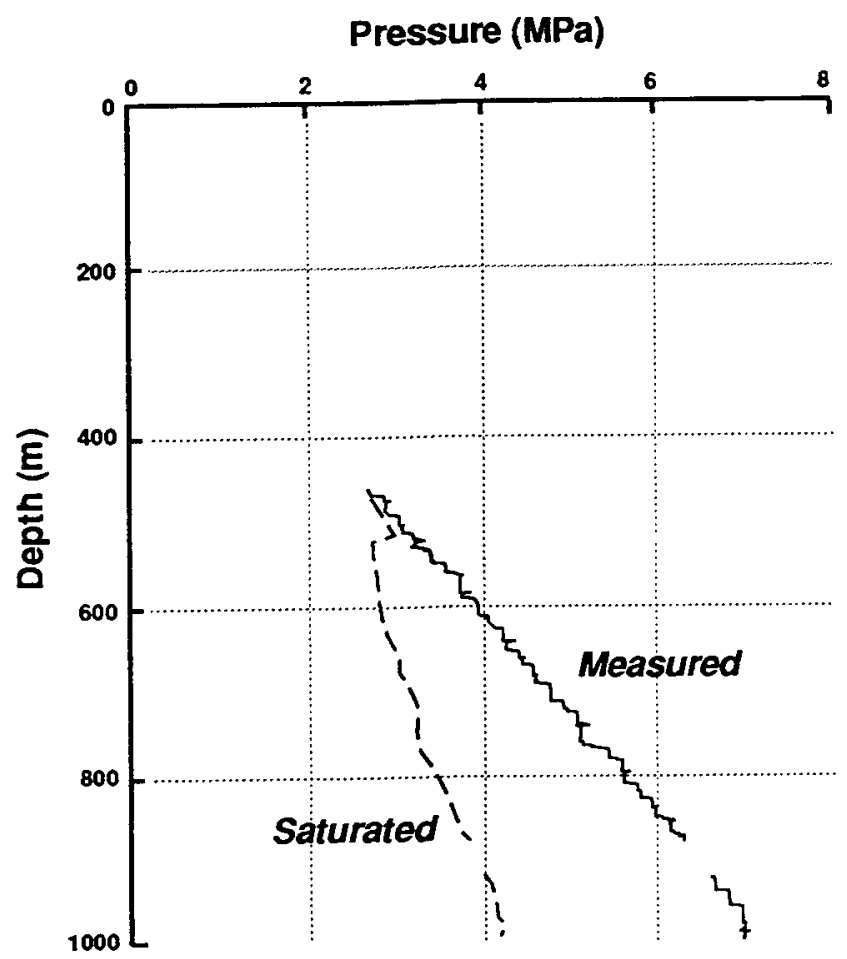

a. Measured and calculated saturation pressures

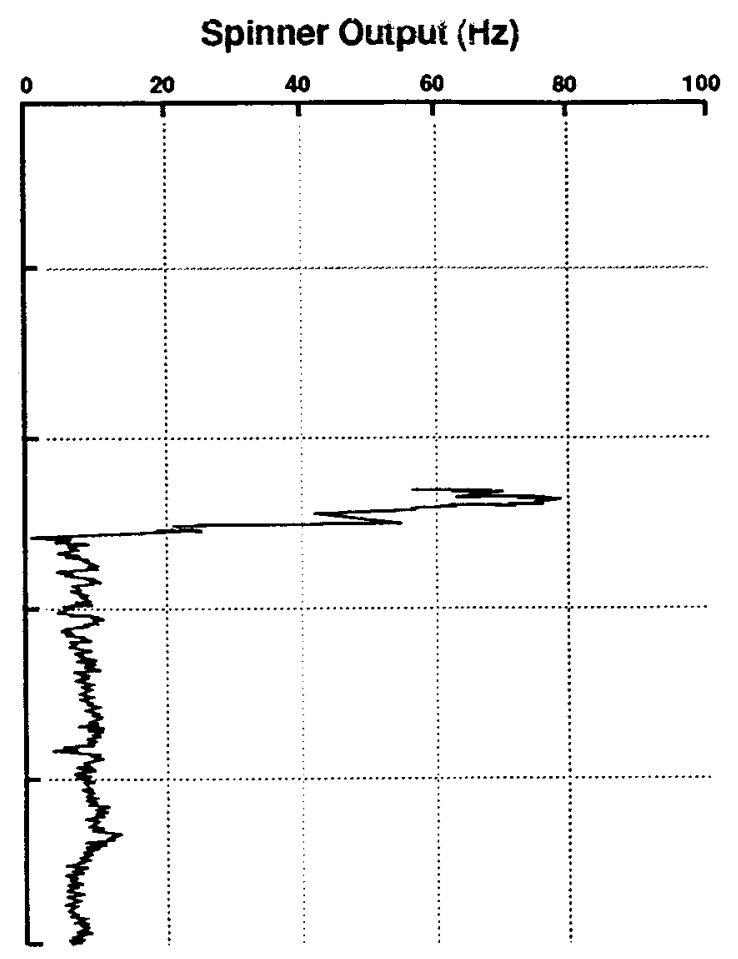

b. Measured spinner output

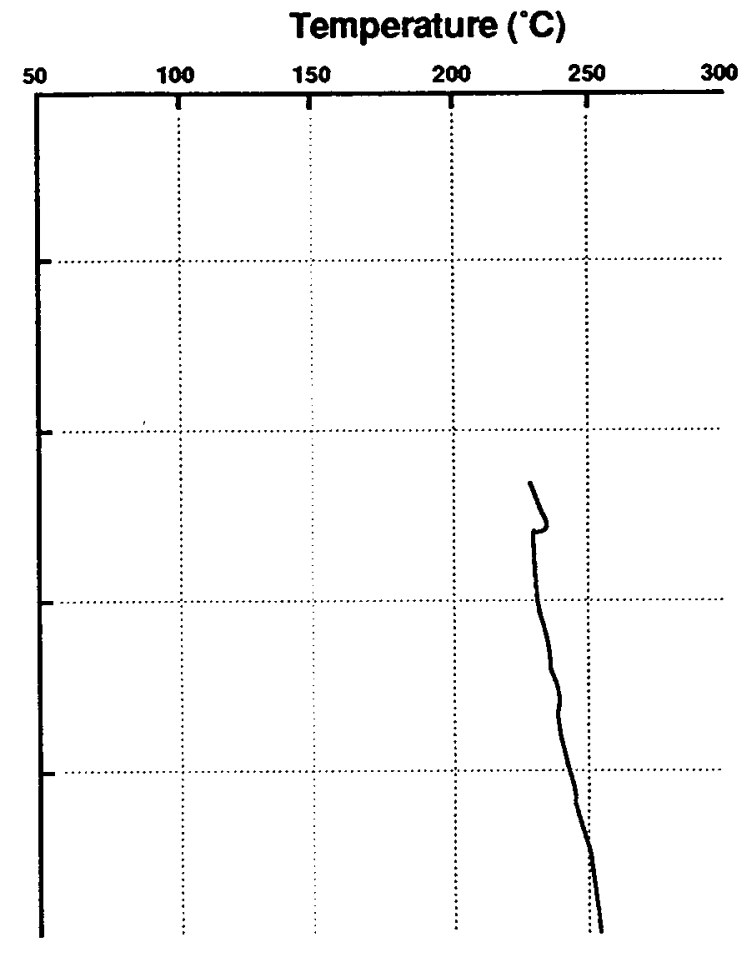

c. Measured temperature

Fig. 9. STP $\log \# 3$ in well ZCQ-4, December 11,1989 (log-in). 


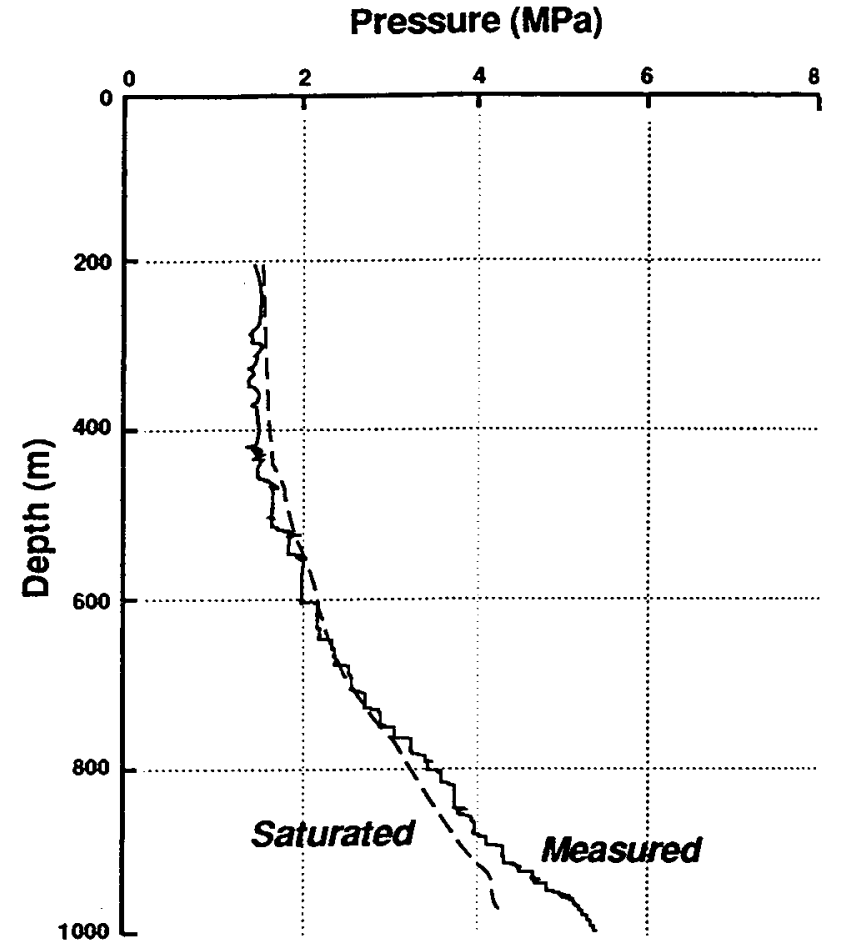

a. Measured and calculated saturation pressures

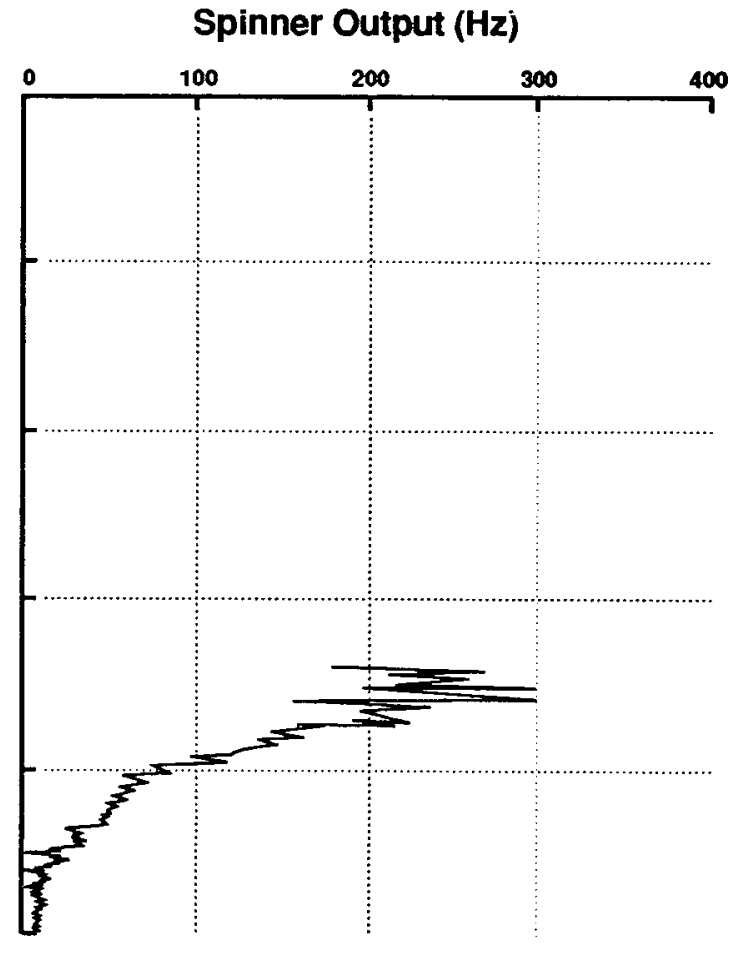

b. Measured spinner output

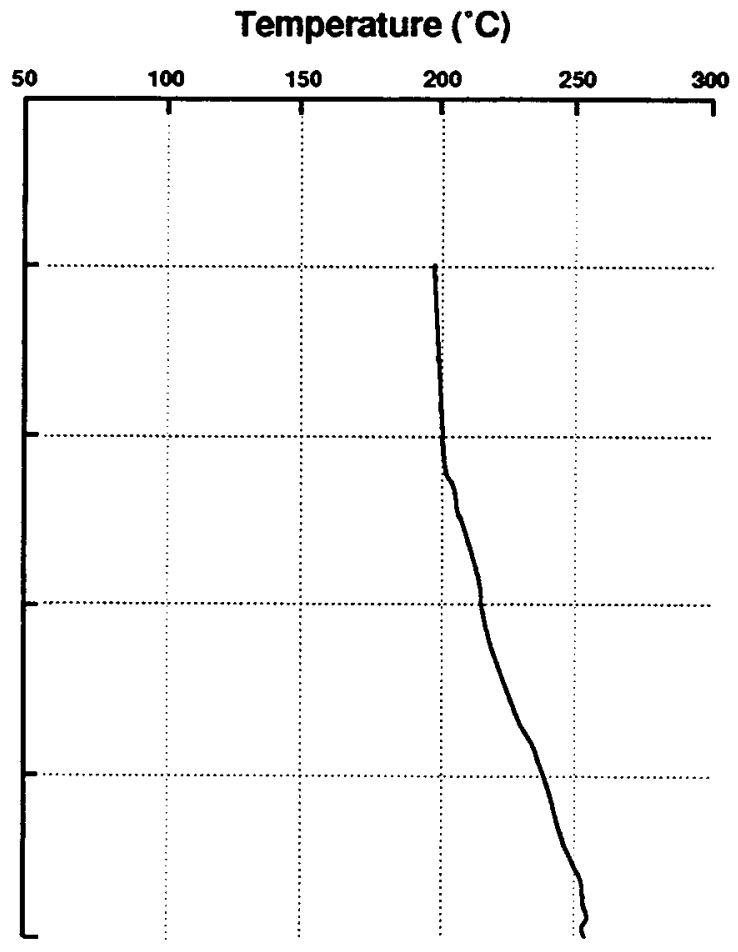

c. Measured temperature

Fig. 10. STP $\log \# 4$ in well ZCQ-4, December 11, 1989 (log-out). Flowing well. 


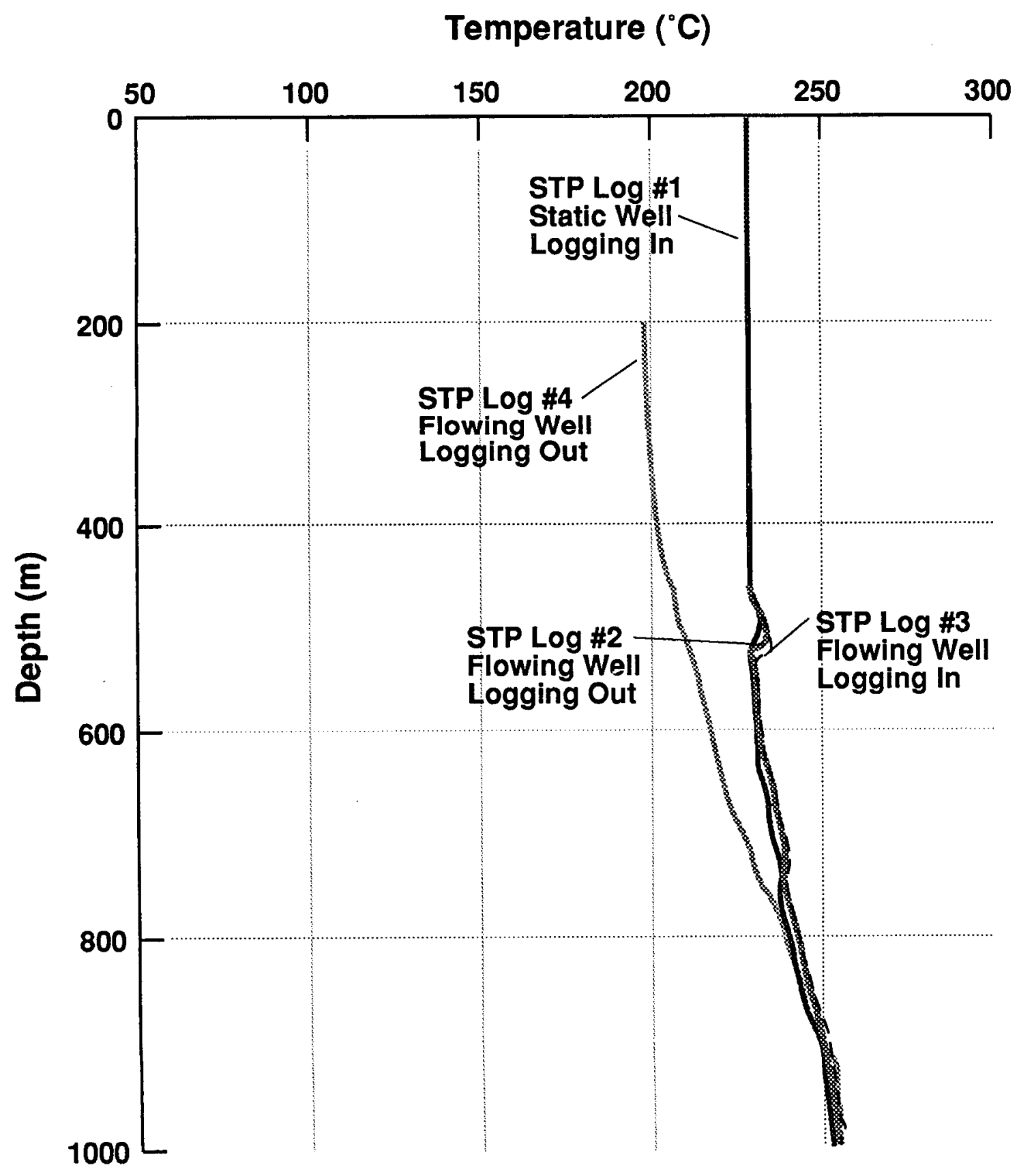

Fig. 11. Temperature data collected in well ZCQ-4. 
A static STP log was run in this well to the bottom of the liner primarily for the temperature profile (Fig. 12). The water level in this well was near $200 \mathrm{~m}$, with some boiling taking place (Fig. 13.)

\section{ZCQ-6}

Another production well, ZCQ-6, was drilled to a depth of $1140 \mathrm{~m}$. This well was cased with $95 / 8$ in. casing to $548 \mathrm{~m}$, and the slotted liner was hung at 540 to $1135 \mathrm{~m}$. The static water level was $800 \mathrm{~m}$; the maximum fluid temperature was $270^{\circ} \mathrm{C}$. The shut-in wellhead pressure, $180 \mathrm{psi}$, dropped to 63 psi under flowing conditions.

The pressure lock and Bowen cable pack-off were rigged up and the temperature/rabbit tool was inserted into the well to run a static temperature log. It was standard practice to run the temperature/rabbit tool first to ensure a safe operating region in the borehole before deploying the more expensive well logging tools. We planned to run a temperature $\log$ to the bottom of the liner $(1140 \mathrm{~m})$, but the tool became set at $794 \mathrm{~m}$. INDE personnel at the site reported a "dog leg" at about $800 \mathrm{~m}$. They had encountered similar problems when running Kuster tools in the well several years before. To get by the obstruction, it had been necessary to flow the well.

ZCQ-6 had been shut-in for at least the past three years, and when the flow control valve to the mufflers was opened for our operation, the wellhead pressure suddenly increased to over 500 psi according to the wellhead pressure gauge. The tool and cable weight indicator also recorded a drop from 700 to 500 1b. The pressure finally decreased to about $150 \mathrm{psi}$, and the tool was started downhole from $740 \mathrm{~m}$ but again became set at $794 \mathrm{~m}$. After several attempts to continue past the obstruction, we aborted the $\log$, shut in the well, and started removing the tool from the hole. However, the tool caught between 615 and $794 \mathrm{~m}$. Repeated runs up the well at various cable velocities failed to free the tool, and the cable finally pulled loose from the cable head, leaving the tool in the well. We assumed that the slotted liner was damaged from the pressure surge when the well was opened to flow. Temperature data recorded in ZCQ-6 during this sequence of events appear in Fig. 14. No other tools were used in this well.

\section{HYDROGEOCHEMICAL INVESTIGATIONS}

\section{A. FLUID COMPOSITIONS}

Field data and analytical data for the thermal and nonthermal waters in the Zunil region appear in Tables I, II, and III. Figure 15 shows the sample locations. Zunil geothermal fluids $(<1500 \mathrm{mg} / \mathrm{kg}$ chlorine, flash-corrected) occur on the dilute side of the typical range of values reported for geothermal brines (500 to $10,000 \mathrm{mg} / \mathrm{kg}$ chlorine; Fournier 1981). Table II shows that the fluids contain relatively high 


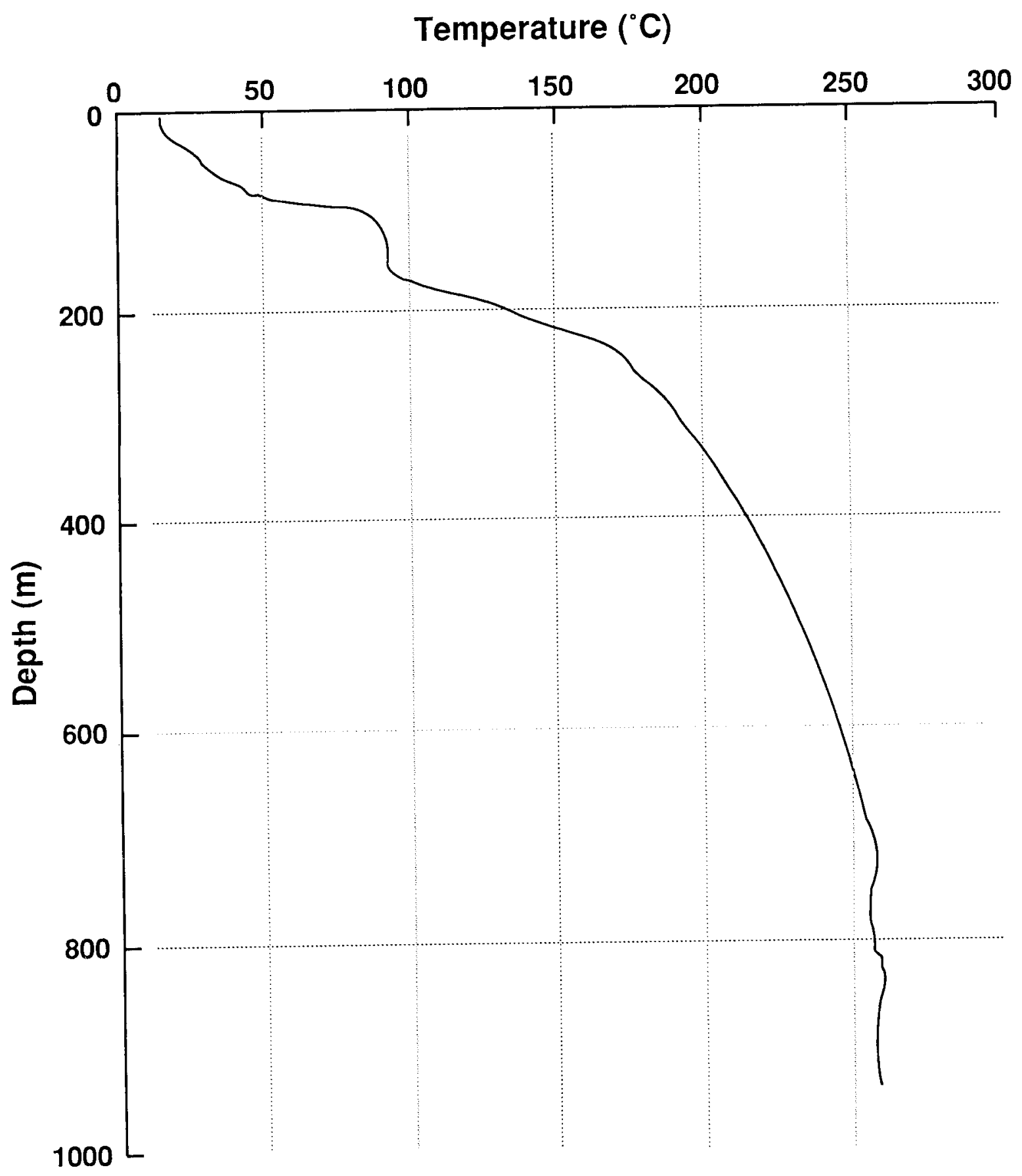

Fig. 11. Temperature data collected in well ZCQ-4. 


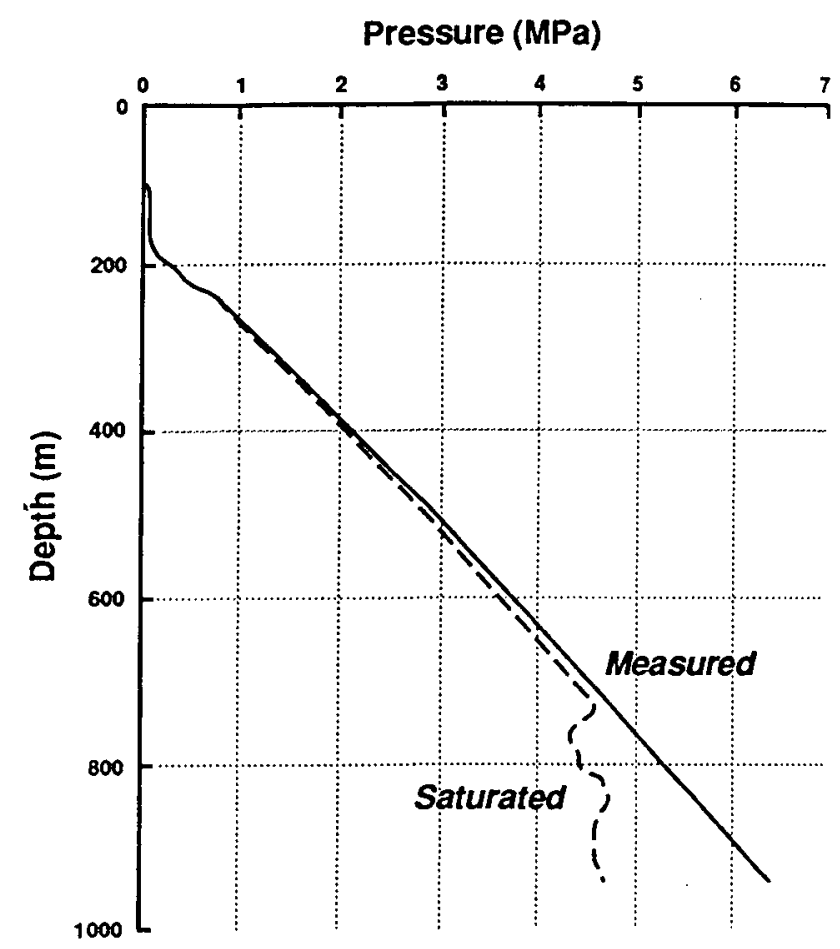

a. Measured and calculated saturation pressures

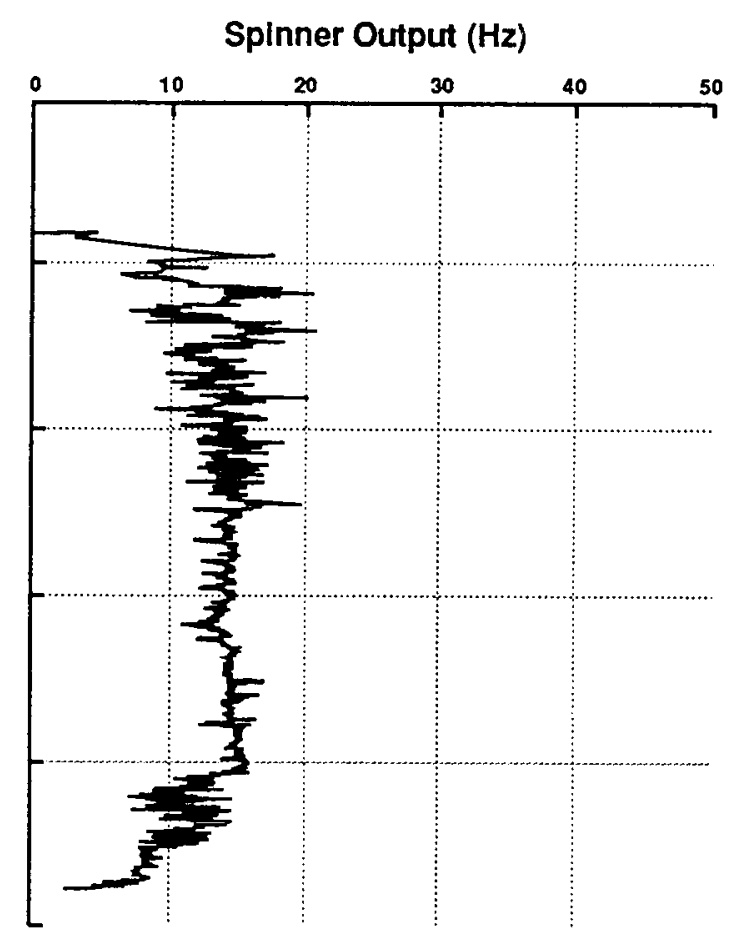

b. Measured spinner output

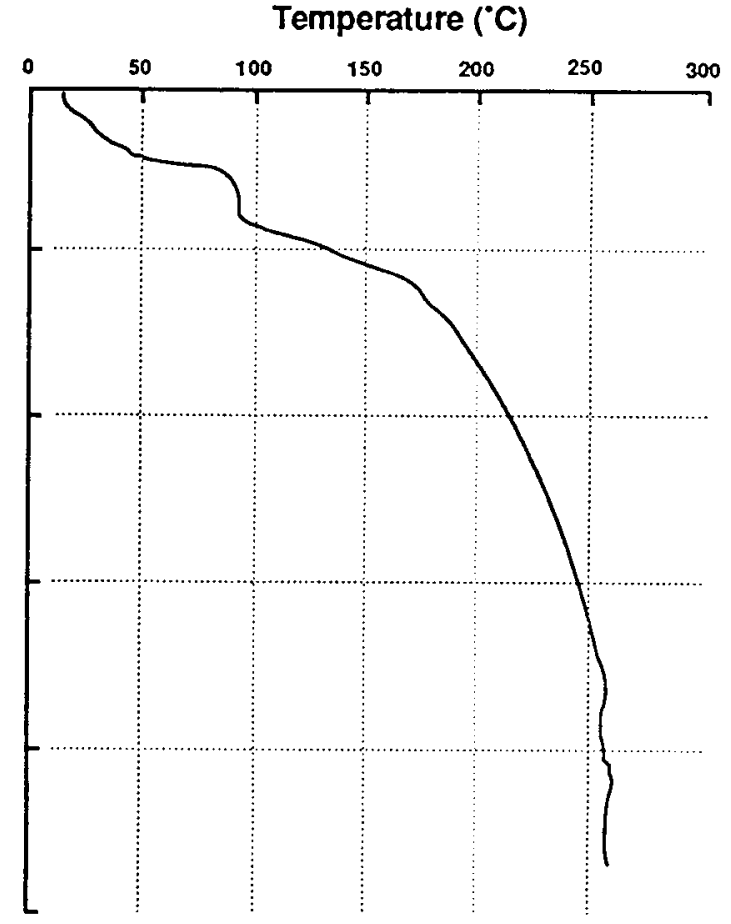

c. Measured temperature

Fig. 13. STP $\log$ in well ZCQ-5, November 2, 1988. Static log. 
concentrations of lithium, arsenic, boron, and bromine. Because of these high concentrations it is relatively easy to trace mixing patterns of the geothermal fluids as they combine with other types of waters found in the area. Trace element chemistry (Table III) shows the same relationships. For example, sample ZTG-28, a hot spring on the Rio Samala north of the town of Zunil, is an obvious mix of thermal water and shallow groundwater. The chemistry of the cold spring (ZTG-12) near Aguas Amargas (ZTG-10, ZTG-11) and the cold spring (ZTG-26) near Baños Sulfurosos (ZTG-25, ZTG-27) shows a thermal influence from the nearby hot springs (Tables II and III) and indicates mixed waters. However, ZTG-19, located $1 \mathrm{~km} \mathrm{SW} \mathrm{of}$ ZTG-28, is composed primarily of thermal water that shows little mixing with shallow groundwater (Figs. 15-19). Compared with geothermal brines, these springs display high $\mathrm{HCO}_{3} / \mathrm{Cl}$, suggesting that subsurface boiling and subsequent loss of $\mathrm{CO}_{2}$ occurs locally in the reservoir. The $\mathrm{CO}_{2}$ is added to near-surface groundwater making the springs rich in bicarbonate (Fournier et al. 1982).

The compositions of the in situ samples are generally similar to those of the other deep reservoir samples (flash-corrected). The waters plot on a relatively crude mixing line. However, a striking range in compositions ( 770 to $1270 \mathrm{mg} / \mathrm{kg}$ chlorine) indicates that producing wells tap horizons of different chemistry. The Zunil field does not consist of one homogeneous aquifer extending throughout the subsurface. Fournier et al. (1982) suggests that a deeper, hotter $\left(290^{\circ} \mathrm{C}\right.$ to $\left.305^{\circ} \mathrm{C}\right)$ source reservoir may underlie the current production zones. If so, the reservoir must exist in the granitic rocks that underlie the volcanic section. Exploration of producing horizons in the granitic rocks is one of the current objectives of MK-Ferguson (1988).

\section{B. GAS COMPOSITIONS}

Gas compositions of the fumaroles and wells that were sampled are listed in Table IV. Although not many samples were obtained, the samples were relatively rich in $\mathrm{CO}_{2}$ and $\mathrm{H}_{2} \mathrm{~S}$ (water-free basis) as is typical of geothermal gases. The data suggest an enrichment in $\mathrm{H}_{2} \mathrm{~S}$ in fluids east of the main production zone. When our data are combined with the data of Giggenbach $(1986,1988)$, we find that this enrichment of $\mathrm{H}_{2} \mathrm{~S}$ is more apparent. The $\mathrm{CO}_{2} / \mathrm{H}_{2} \mathrm{~S}$ ratio is sometimes used in geothermal exploration to look for upflow zones (Hedenquist et al.). The lowest ratio in a suite of samples is often closest to the upflow zone. A general west to east decrease in $\mathrm{CO}_{2} / \mathrm{H}_{2} \mathrm{~S}$ is evident when all gas data are plotted (Fig. 20), indicating 


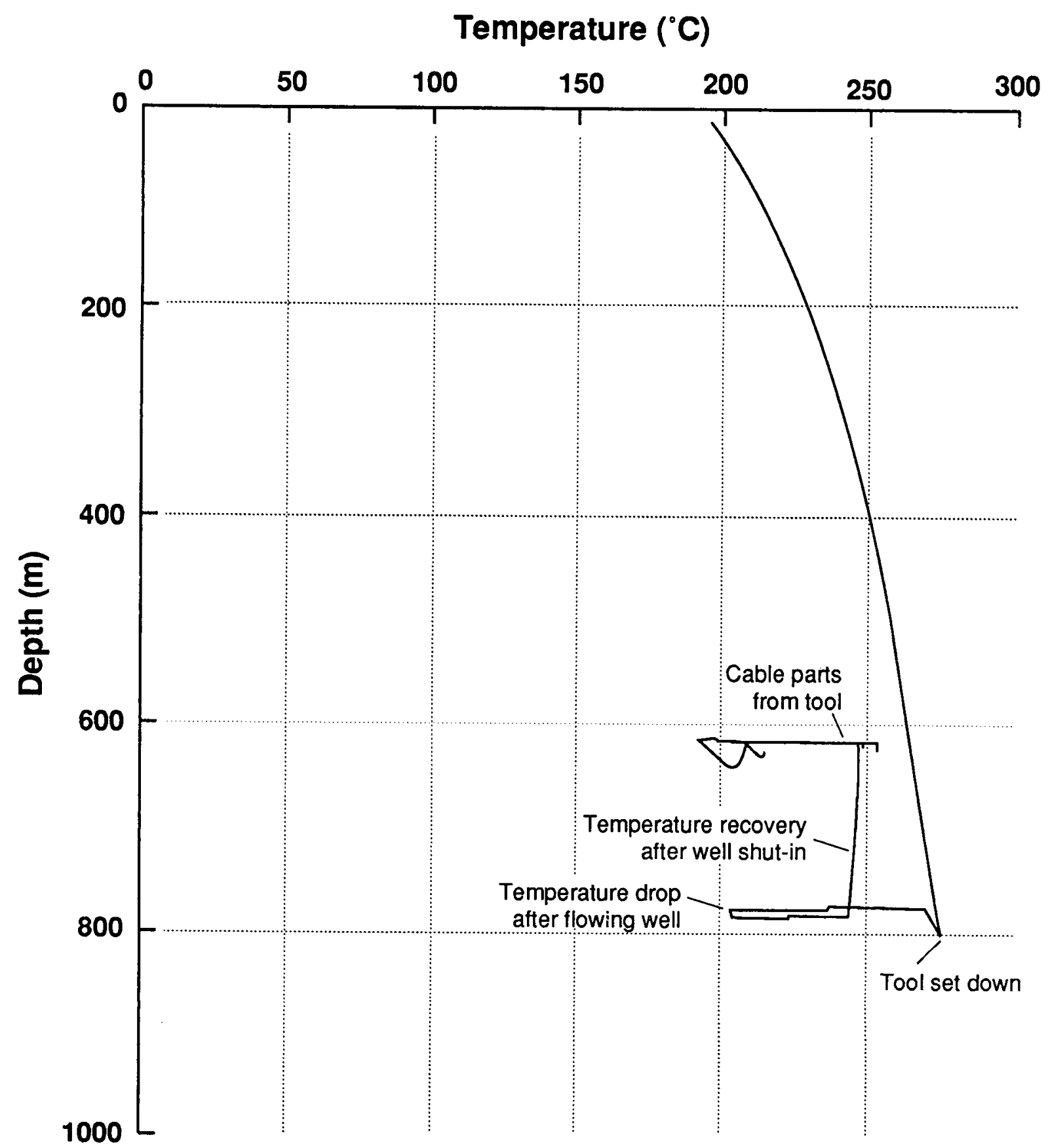

Fig. 14. Measured temperatures in well ZCQ-6, November 1988. 


\begin{tabular}{|c|c|c|c|c|c|c|c|c|}
\hline Sample & Description & Date & $\begin{array}{l}\text { Temp } \\
\left({ }^{\circ} \mathrm{C}\right)\end{array}$ & $\begin{array}{l}\mathrm{pH} \\
(\mathrm{F}) \\
\end{array}$ & $\begin{array}{l}\text { Flow Rate } \\
(1 / \mathrm{min})\end{array}$ & $\begin{array}{c}\text { Vol. of Sample } \\
\text { Bottle } \\
(l)\end{array}$ & $\begin{array}{l}\text { Vol. of } \\
\text { Sample } \\
(l) \\
\end{array}$ & $\begin{array}{c}\text { Depth } \\
\text { (m) }\end{array}$ \\
\hline ZTG-1 & Warm spring (Z-58), $100 \mathrm{~m} \mathrm{~W}$ of ZCQ-5 & $10 / 26 / 88$ & $28.8^{\mathrm{a}}$ & 6.5 & 10 & -- & -- & $\ldots$ \\
\hline ZTG-2 & Cold spring (Z-47B), $100 \mathrm{~m} \mathrm{S10E}$ of ZTG-1 & $10 / 26 / 88$ & $24.5^{\mathrm{a}}$ & 6.5 & 64 & --- & $\cdots$ & -.. \\
\hline ZTG-3 & Hot spring (Z-47), from iron pipe & $10 / 27 / 88$ & $90.2^{\mathrm{a}}$ & 3.5 & 40 & --- & $\ldots$ & -.- \\
\hline ZTG-4 & Hot spring, $5 \mathrm{~m} \mathrm{SW}$ of $Z T \mathrm{TG}-3$ & $10 / 27 / 88$ & $60.8^{\mathrm{a}}$ & 3.5 & 5 & -.- & $\ldots$ & --- \\
\hline ZTG-5 & Fuentes Georgines (Z-34) & $10 / 28 / 88$ & $51.7^{\mathrm{a}}$ & 20 & 15 & -.. & -- & -- \\
\hline ZTG-6 & Fuentes Georgines (Z-31), lower pool & $10 / 28 / 88$ & $40.2^{\mathrm{a}}$ & 20 & 10 & --- & --- & -.. \\
\hline ZTG-7 & Steam condensate, Las Fresas & $10 / 28 / 88$ & $94.2^{\mathrm{a}}$ & 5.5 & $\ldots$ & -.- & -- & ... \\
\hline ZTG-8 & Steam condensate (ZF-38) & $10 / 28 / 88$ & $94.2^{\mathrm{a}}$ & 6.5 & --- & -.. & -.. &.-- \\
\hline ZTG-9 & Fumarole Negro (ZF-36) & 10/30/88 & $94.7^{\mathrm{a}}$ & 4.75 & --- & --- & -.. &.-- \\
\hline ZTG-10 & Aguas Amargas (Z-19) & $10 / 30 / 88$ & $53.3^{\mathrm{a}}$ & 2.0 & --- & $\cdots$ & $\ldots$ & -- \\
\hline ZTG-11 & Aguas Amargas (Z-19), $20 \mathrm{~m} \mathrm{NNW}$ of ZTG-10 & $10 / 30 / 88$ & $68.4^{\mathrm{a}}$ & 2.0 & $\cdots$ &.-- & $\ldots$ & --- \\
\hline ZTG-12 & Aguas Amargas (Z-19A), cold spring & $10 / 30 / 88$ & $18.3^{\mathrm{a}}$ & 3.5 & -- & -.. & $\ldots$ & $\ldots$ \\
\hline ZTG-13 & Downhole at $\mathrm{ZCQ}-3(671 \mathrm{~m})$ & $10 / 31 / 88$ & $258^{\mathrm{b}}$ & 5.5 & $\cdots$ & 3.911 & 2.387 & 671 \\
\hline ZTG-14 & Cold spring (Z-42) & $10 / 31 / 88$ & $17.3^{\mathrm{a}}$ & 6.5 & 10 & $\cdots$ & $\ldots$ & ... \\
\hline ZTG-15 & Cold spring, Chicua & $11 / 01 / 88$ & $14.4^{\mathrm{a}}$ & 6.5 & 1 & ... & ... & -.. \\
\hline ZTG-16 & Weirbox at ZCQ-6 & $11 / 01 / 88$ & $278^{\mathrm{b}}$ & 8.5 & $\ldots$ & -- & -.. & --. \\
\hline ZTG-17 & Rain water at ZCQ-1 & $11 / 02 / 88$ & $\cdots$ & --- & $\cdots$ & $\cdots$ & $\ldots$ & -- \\
\hline ZTG-18 & Downhole at ZCQ-5 $(775 \mathrm{~m})$ & $11 / 02 / 88$ & $255^{\mathrm{b}}$ & 5.5 & $\cdots$ & 3.911 & 2.579 & 775 \\
\hline ZTG-19 & Hot spring (Z-17) & $11 / 03 / 88$ & $74.4^{\mathrm{a}}$ & 7.75 & 100 & --- & --- & $\cdots$ \\
\hline ZTG-20 & Cerro Quemado, rock sample & $11 / 03 / 88$ & -- & $\cdots$ & $\cdots$ & -.- & --. & --- \\
\hline ZTG-21 & Fumarole Azufalito, gas sample & $02 / 27 / 89$ & $92.8^{\mathrm{a}}$ & 3.00 & -.- & --- & -- & --- \\
\hline ZTG-22 & Furmarole near Georgina, gas sample & $02 / 28 / 89$ & $94.0^{\mathrm{a}}$ & 3.50 & --- & --. & --. & $\cdots$ \\
\hline ZTG-23a & Steam condensate, Fumarole Negro & $02 / 28 / 89$ & $94.0^{\mathrm{a}}$ & 3.25 & --- & $\ldots$ & -.- & --- \\
\hline ZTG-23b & Gas sample, Fumarole Negro & $02 / 28 / 89$ & $94.0^{\mathrm{a}}$ & 3.25 & --- & $\ldots$ & --- & $\cdots$ \\
\hline ZTG-24 & Agua Tibia, $1.5 \mathrm{~km}$ NE of Ostuncalco & $12 / 06 / 89$ & $21.2^{\mathrm{a}}$ & 7.00 & 200 & -.- & ..- & -.. \\
\hline ZTG-25 & Baños Sulfurosos El Recreo & $12 / 07 / 89$ & $41.3^{\mathrm{a}}$ & 6.00 & 15 & --. & $\ldots$ & $\cdots$ \\
\hline ZTG-26 & $3 \mathrm{~m} \mathrm{E}$ of $Z \mathrm{TG}-22$ cold spring & $12 / 07 / 89$ & $20.1^{\mathrm{a}}$ & 6.50 & 3 & -.- & ... & -.. \\
\hline ZTG-27 & Baños Sulfurosos Well & $12 / 07 / 89$ & $45.4^{\mathrm{a}}$ & 6.50 & pumped & --- & $\ldots$ & $\cdots$ \\
\hline ZTG.28 & Hot spring on NW bank of Río Samala & $12 / 07 / 89$ & $61.4^{\mathrm{a}}$ & 7.00 & 10 & --. & ... & $\cdots$ \\
\hline ZTG-29 & ZC-11 direct use well from weirbox & $12 / 08 / 89$ & $255^{\mathbf{b}}$ & 7.50 & 33 & -.- & $\ldots$ & $\ldots$ \\
\hline ZTG-30 & Make up water for ZC-11, warm spring & $12 / 08 / 89$ & $30.5^{\mathrm{a}}$ & 6.80 & 5 & ... & $\ldots$ & $\ldots$ \\
\hline ZTG-31 & Steam side of separator at ZC-11 & $12 / 09 / 89$ & $255^{\mathrm{b}}$ & 5.30 & -.. & ... & .. & $\cdots$ \\
\hline ZTG-32 & Total flow from separator at ZC-11 & $12 / 09 / 89$ & $255^{\mathbf{b}}$ & 5.00 & $\cdots$ & $\ldots$ & -- & $\cdots$ \\
\hline ZTG-33 & Downhole at ZCQ-4 $(900 \mathrm{~m})$ & $12 / 11 / 89$ & $258^{\mathrm{b}}$ & 5.00 & $\cdots$ & 3.911 & 3.043 & 900 \\
\hline ZTG-34 & Hot well $0.5 \mathrm{~km} \mathrm{~S}$ of Totonicapán & $12 / 11 / 89$ & $46.0^{\mathrm{a}}$ & 6.50 & -.. & ... & $\ldots$ & $\cdots$ \\
\hline ZTG-35 & Cold spring $0.7 \mathrm{~km}$ W of Totonicapán & $12 / 11 / 89$ & $19.1^{\mathrm{a}}$ & 6.00 & 7 & --- & $\ldots$ & $\cdots$ \\
\hline ZTG-36 & Weirbox at $Z C Q-4$ & $12 / 11 / 89$ & $258^{\mathrm{b}}$ & 7.50 & 1080 & $\cdots$ & -.- & $\cdots$ \\
\hline ZTG-37 & Steam condensate, Baños Los Vahos & $12 / 12 / 89$ & $26.0^{\mathrm{a}}$ & 6.00 & $\cdots$ & $\ldots$ & ... & -.- \\
\hline ZTG-38 & Cold spring (Z-73) & $12 / 12 / 89$ & $14.9^{\mathrm{a}}$ & 6.00 & seep & $\cdots$ & $\cdots$ & $\cdots$ \\
\hline ZTG-39 & ZP-6 exploration well & $12 / 12 / 89$ & $94.6^{\mathrm{a}}$ & 8.00 & 15 & -.- & $\ldots$ & $\ldots$ \\
\hline ZTG-40 & Cold spring off cliff above Río Zamaca & $12 / 12 / 89$ & $15.3^{\mathrm{a}}$ & 6.00 & 30 & --- & -.- & --- \\
\hline ZTG-41 & Weirbox at ZCQ-3 & $12 / 12 / 89$ & $258^{\mathrm{b}}$ & 8.30 & 2017 & --- & --- & --- \\
\hline
\end{tabular}

acollection temperature.

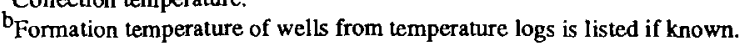


TABLE II. Major Element Chemistry for Wells, Hoy/Cold Springs and Fumaroles in the Zunil-Quetzaltenango Region, Guatemala ${ }^{\mathbf{a}}$ (all values in mg/kg, except where noted)

\begin{tabular}{|c|c|c|c|c|c|c|c|c|c|c|c|c|c|c|c|c|c|c|c|c|c|}
\hline Sample & Description & $\begin{array}{l}\text { Temp } \\
{ }^{\circ} \mathrm{C}\end{array}$ & $\begin{array}{l}\mathrm{pH} \\
\text { (lab) }\end{array}$ & As & B & $\mathrm{Br}$ & $\mathrm{Ca}$ & $\mathrm{Cl}$ & $\mathrm{CO}_{3}$ & $\mathrm{~F}$ & $\mathrm{HCO}_{3}$ & $\mathrm{~K}$ & $\mathbf{L i}$ & $\mathrm{Mg}$ & $\mathrm{Na}$ & $\mathrm{SiO}_{2}$ & $\mathrm{SO}_{4}$ & Sr & TDS & $\begin{array}{c}\text { Cation } \\
\Sigma \\
\end{array}$ & $\begin{array}{c}\text { Anion } \\
\Sigma\end{array}$ \\
\hline \multirow{2}{*}{\multicolumn{22}{|c|}{ Fumaroles, Warm and Hot Springs }} \\
\hline & & & & & & & & & & & & & & & & & & & & & 3.348 \\
\hline ZTG-3 & Hot spring ( $(-47)$, from iron pipe & 90.2 & 2.78 & $<0.05$ & $<0.1$ & $<0.1$ & 41.9 & 5.4 & 0 & 0.38 & 0 & 7.9 & 0.03 & 23.2 & 19.2 & 159 & 377 & 0.11 & 656.2 & 8.076 & 8.083 \\
\hline $\mathrm{ZTG}-4$ & Hot spring, $5 \mathrm{~m} \mathrm{SW}$ of $Z T \mathrm{TG}-3$ & 60.8 & 2.85 & $<0.05$ & $<0.1$ & $<0.1$ & 47.5 & 5.7 & 0 & 0.41 & 0 & 8.0 & 0.04 & 25.6 & 19.2 & 168 & 455 & 0.11 & 764.7 & 10.360 & 9.732 \\
\hline ZTG-5 & Fuentes Georgines (Z-34) & 51.7 & 2.44 & $<0.05$ & 1.7 & $<0.1$ & 38.4 & 5.4 & 0 & 0.39 & 0 & 27 & 0.05 & 18.5 & 79 & 182 & 818 & 0.10 & 1200.4 & 17.355 & 17.409 \\
\hline ZTG -6 & Fuentes Georgines (Z-31), lower po & 40.2 & 2.26 & $<0.05$ & 1.7 & $<0.1$ & 64.9 & 4.6 & 0 & 0.42 & 0 & 34 & 0.08 & 25.5 & 121 & 276 & 1459 & 0.10 & 2057.3 & 31.166 & 30.805 \\
\hline ZTG-7 & Steam condensate, Las Fresas & $\ldots$ & 4.59 & $<0.05$ & $<0.1$ & $<0.1$ & $<0.1$ & $<0.5$ & 0 & 0.20 & 22.0 & 1.1 & $<0.01$ & 0.27 & 0.9 & $<0.2$ & 2.5 & $<0.01$ & 27.7 & 0.131 & 0.424 \\
\hline ZTG-8 & Steam condensate (ZF-38) & $\ldots$ & 6.45 & $<0.05$ & $<0.1$ & $<0.1$ & 1.1 & 0.7 & 0 & 0.49 & 19.5 & 0.7 & $<0.01$ & 0.45 & 1.2 & 3 & 5.2 & $<0.01$ & 35.8 & 0.282 & 0.474 \\
\hline ZTG-9 & Fumarole Negro, mud pot (ZF-36) & 94.7 & 4.23 & $<0.05$ & $<0.1$ & $<0.1$ & 49.7 & 7.3 & 0 & 0.24 & 0 & 11.6 & $<0.01$ & 22.5 & 50 & 160 & 344 & 0.31 & 658.5 & 7.530 & 7.441 \\
\hline ZTG-10 & Aguas Amargas (Z-19) & 53.3 & 2.35 & $<0.05$ & 1.4 & $<0.1$ & 32.9 & 4.7 & 0 & 0.44 & 0 & 23 & 0.04 & 10.6 & 71 & 191 & 999 & 0.18 & 1391.3 & 21.618 & 21.173 \\
\hline ZTG-11 & Aguas Amargas $(\mathrm{Z}-19), 20 \mathrm{~m}$ NNW of ZTG-1 & 68.4 & 2.28 & $<0.05$ & 2.3 & $<0.1$ & 32.7 & 4.9 & 0 & 0.46 & 0 & 33 & 0.05 & 10.7 & 84 & 183 & 1180 & 0.18 & 1593.4 & 25.215 & 25.022 \\
\hline ZTG.19 & Hot spring ( $2-17)$ & 74.4 & 7.41 & 0.34 & 5.6 & 0.5 & 40.2 & 186 & 0 & 0.74 & 665 & 32 & 0.54 & 40.0 & 313 & 195 & 202 & 0.41 & 1682.8 & 19.798 & 20.639 \\
\hline ZTG-23 & Steam condensate, $F$ & 94.0 & -.. & $\ldots$ & $<0.05$ & $<0.05$ & ... & 0.6 & --. & 0.13 & -.- & 0.1 & $\ldots$ & $\ldots$ & 0.1 & $\ldots$ & 5.3 & ... & -.- & ... & -. \\
\hline ZTG-25 & Baños Sulfurosos, El Recreo & 41.3 & 6.91 & $<0.05$ & 0.64 & 0.08 & 21.0 & 23.9 & 0 & 0.25 & 193 & 7.8 & 0.11 & 10.46 & 76 & 161 & 64.0 & 0.08 & 559.4 & 5.475 & 5.232 \\
\hline ZTG-28 & Hot spring on NW B & 61.4 & 7.60 & 0.27 & 2.42 & 0.23 & 13.8 & 70.8 & 0 & 0.40 & 210 & 14.4 & 0.28 & 8.78 & 116 & 22 & 73.2 & 0.08 & 670.4 & 6.869 & 7.168 \\
\hline ZTG.30 & Make-up water for $\mathrm{ZC}-11$, warm spring & 30.5 & 7.70 & $<0.05$ & 0.17 & $<0.05$ & 26.0 & 5.06 & 53.5 & 0.19 & 136 & 5.7 & 0.05 & 22.6 & 29 & 535 & 20.4 & 0.15 & 414.6 & 4.580 & 4.735 \\
\hline ZTHG-37 & Steam condensate, Baños Los Vahos & 26.0 & 6.06 & $<0.05$ & 0.12 & $<0.05$ & $<0.1$ & 1.11 & 0 & $<0.02$ & 18.3 & 0.4 & 0.01 & $<0.01$ & 0.8 & 1 & 0.16 & 0.04 & 22.3 & 0.050 & 0.341 \\
\hline \multicolumn{22}{|c|}{ Cold Springs } \\
\hline $\mathrm{ZTG}-2$ & Cold sprin & 24.5 & 7.19 & $<0.05$ & $<.1$ & $<0.1$ & 17.6 & 4.4 & 0 & 0.32 & 121 & 3.7 & 0.02 & 12.9 & 10.2 & 90 & 15.4 & 0.09 & 285.8 & 2.486 & 2.608 \\
\hline ZTG-12 & Aguas Amargas (Z-1s & 18.3 & 2.95 & $<0.05$ & 0.2 & $<0.1$ & 25.2 & 5.7 & 0 & 0.33 & 0 & 11.2 & 0.02 & 8.01 & 36 & 118 & 358 & 0.14 & 588.1 & 7.758 & 7.722 \\
\hline ZTG-14 & Cold spring (Z-42) & 17.3 & 7.11 & $<0.05$ & $<0.1$ & $<0.1$ & 12.0 & 2.4 & 0 & 0.27 & 89.1 & 3.5 & $<0.01$ & 6.82 & 9.3 & 66 & 1.7 & 0.09 & 202.3 & 1.664 & 1.759 \\
\hline ZTG-15 & Cold spr & 14.4 & 7.06 & $<.05$ & $\leqslant .1$ & $<0.1$ & 19.6 & 4.4 & 0 & 0.23 & 98.8 & 45 & $\alpha \hat{v} \bar{i}$ & $1 \overline{0} . \overline{8}$ & 8.5 & 68 & 12.7 & 0.12 & 250.4 & 2.360 & 2.385 \\
\hline ZTG-24 & Agua Tibiz, $1.5 \mathrm{~km}$ NE of Osuncal & 21.2 & 7.50 & $<0.05$ & 0.11 & $<0.05$ & 11.5 & 1.70 & 0 & 0.06 & 78.1 & 3.7 & 0.01 & 5.93 & 9.0 & 82 & 5.07 & 0.07 & 205.8 & 1.557 & 1.586 \\
\hline ZTG-26 & $3 \mathrm{mEc}$ & 20.1 & 7.23 & $<0.05$ & 0.37 & $<0.05$ & 77.7 & 41.0 & 0 & 0.13 & 153 & 7.8 & 0.12 & 41.4 & 64 & 98 & 84.4 & 0.26 & 833.5 & 10.289 & 9.737 \\
\hline ZTG-35 & of Totonicar & 19.1 & 7.10 & $<0.05$ & $<0.05$ & $<0.0$ & 11.0 & 3.71 & 0 & 0.0 & 80.5 & 1.2 & 0.0 & 5.93 & 11.9 & 73 & 7.93 & 0.08 & 204.6 & 1.594 & 1.744 \\
\hline ZTG-38 & Cold sprin & 14.9 & 6.86 & $<0.05$ & 0.11 & $<0.0$ & 92.9 & 5.3. & 0 & 0.42 & 72 & 2.0 & 0.02 & 11.6 & 13.5 & 73 & 230 & 0.05 & 510.8 & 6.236 & 6.347 \\
\hline ZTG -40 & Cold spring off cliff on Río Zamaca & 15.3 & 7.26 & $<0.05$ & $<0.05$ & $<0.05$ & 11.1 & 3.55 & 0 & 0.03 & 62.2 & 3.2 & $<0.01$ & 4.22 & 6.9 & 57 & 9.60 & 0.05 & 163.6 & 1.289 & 1.412 \\
\hline \multicolumn{22}{|c|}{ Geothermal and Other Wells } \\
\hline ZTG-13 & Downhole at ZCQ -3 ( 6 & 258 & 6.18 & 1. & 23.9 & 4 & \multicolumn{2}{|c|}{8.11065} & 0 & 2.49 & 62.2 & 12 & 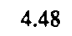 & 0.35 & 65 & 460 & 28.1 & 0.15 & 2407.0 & 29.907 & 33.178 \\
\hline ZTG. $16^{b}$ & Weirbox at ZCQ-6 & 278 & 8.27 & 3.61 & 16.27 & 2.59 & \multicolumn{2}{|c|}{6.07768} & 36.9 & 2.08 & 0 & 82.9 & 3.7 & 0.29 & 43 & 291 & 40 & 0.15 & 4221.5 & 55.485 & 60.322 \\
\hline ZTG-18 & $5(775 \mathrm{~m})$ & 255 & 5.70 & $<0.05$ & 27.8 & 5.1 & \multicolumn{2}{|c|}{18.21367} & 0 & 3.5 & 50.0 & 128 & 8. & $<0.01$ & 80 & 470 & 18.9 & 0.16 & 2928.2 & 40.407 & 40.995 \\
\hline ZTG-27 & Baños Sulfurosos & 45.4 & 7.11 & $<0.05$ & 1.0 & 0.09 & \multirow{2}{*}{\multicolumn{2}{|c|}{$\begin{array}{lr}22.5 & 27 . \\
23.341269\end{array}$}} & 0 & 0.15 & 231 & 9.8 & 0.15 & 11.1 & 93 & 172 & 57.9 & 0.09 & 638.9 & 6.390 & 6.024 \\
\hline ZTG-29b & Il from weirbo & 255 & 8.08 & 7.33 & 35.32 & 4.62 & & & 20.5 & 1.42 & 0 & 71.2 & 4.57 & 0.1 & 822 & 321 & 83.5 & 0.36 & 3906.3 & 57.469 & 58.658 \\
\hline ZTG-31 & Steam & 255 & 6. & 0 . & 2. & 0. & 1.5 & 79. & 0 & 0.14 & 34 & 5 & 0. & 0 & 51 & 22 & 5.65 & 0.03 & 211.9 & 2.783 & 3.101 \\
\hline ZTG-32 & Total fl & 255 & 6.55 & $<0.05$ & $<0.05$ & $<0.0$ & 0.2 & 0.85 & 0 & $<0.02$ & 34 & 0.3 & 0.01 & 0.10 & 1.2 & 3 & 0.43 & $<0.01$ & 47.1 & 0.372 & 0.620 \\
\hline ZTG-33 & Dowr & 258 & 5.8 & 0.16 & 24.3 & 3. & 11.2 & 903 & 0 & 2.85 & 53.7 & 113 & & & 601 & 565 & 32.0 & 0.13 & 2298.5 & 30.525 & 28.219 \\
\hline ZTG-34 & Hot well $0.5 \mathrm{~km} \mathrm{~S}$ of To & 46.0 & 7.63 & $<0$ & & 0. & 11.0 & 23.5 & 0 & & 160 & 9.4 & 0.52 & 2.04 & 75 & 111 & 55.7 & 0.17 & 458.8 & 4.668 & 4.615 \\
\hline ZTG-36b & Weirbox at ZCQ-4 & 258 & 8.25 & 6.6 & 26.35 & 3.56 & 17.94 & 931 & 0 & 1.36 & 38.8 & 94.03 & 5.59 & 0.08 & 603 & 374 & 33.2 & 0.21 & 3234.4 & 45.866 & 43.681 \\
\hline ZTG $-39^{b}$ & ZP-6 exploration well & 94.6 & 8.27 & 12.34 & 33.4 & 4.25 & 41.141 & 1084 & 19.36 & 3.37 & 0 & 29.6 & 5.35 & 0.14 & 774 & 320 & 106 & 0.71 & 2370.6 & 41.509 & 40.0 \\
\hline $\mathrm{ZTG}-41^{\mathrm{b}}$ & Weirbox at $Z C Q-3$ & 258 & 8.41 & 7.26 & 27.9 & 4.24 & 11.371 & 1081 & 11.8 & 3.13 & 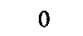 & 139 & 5.75 & 0.08 & 718 & 540 & 19.5 & 0.20 & 3954.7 & 55.288 & 51.037 \\
\hline
\end{tabular}

a Analyses by P. E. Trujillo (Los Alamos National Laboratory).

b Chemistry corrected for flashing according to formation temperatures (see Table I). 
TABLE III. Trace Element Chemistry of Wells, Hoy/Cold Springs, and Fumaroles in the Zunil-Quetzaltenango Region, Guatemala (all values in mg/kg)

\begin{tabular}{|c|c|c|c|c|c|c|c|c|c|c|c|c|c|c|c|c|c|c|c|c|c|c|c|c|c|}
\hline mple No & Description & $\mathrm{Ag}$ & $\mathrm{Al}$ & Ba & $\mathrm{Cd}$ & Co & $\mathrm{Cr}$ & Cs & $\mathrm{Cu}$ & $\mathrm{Fe}$ & $\mathrm{Hg}$ & I & $\mathrm{Mn}$ & Mo & $\mathrm{NH}_{4}$ & $\mathrm{Ni}$ & $\mathrm{NO}_{3}$ & $\mathrm{~Pb}$ & $\mathrm{PO}_{4}$ & $\mathbf{R b}$ & $\mathbf{S b}$ & Se & $\mathrm{S}_{2} \mathrm{O}_{3}$ & $\mathbf{U}$ & $\mathbf{Z n}$ \\
\hline \multicolumn{26}{|c|}{ Fumaroles and Warm and Hot Springs } \\
\hline ZTG-1 & Warm spring (Z-58), $100 \mathrm{~m}$ W of $Z$ & $<0.001$ & $<0.1$ & 0.04 & $<0.002$ & $<0.002$ & $<0.002$ & $<0.005$ & 0.002 & $<0.01$ & $<0.1$ & $<0.05$ & $<0.01$ & $<0.002$ & 0.06 & 0.006 & 8.3 & $<0.002$ & 0.2 & 0.014 & $<0.1$ & $<0.1$ & $<0.05$ & $<0.1$ & $<0.01$ \\
\hline ZTG-3 & Hot spring ( $(-47)$, from iron pipe & $<0.001$ & 4.9 & 0.02 & $<0.002$ & $<0.002$ & $<0.002$ & $<0.005$ & $<0.002$ & 11.9 & $<0.1$ & $<0.05$ & 0.80 & $<0.002$ & 2.19 & 0.005 & $<0.1$ & $<0.002$ & -0.1 & 0.042 & $<0.1$ & $<0.1$ & $<0.05$ & $<0.1$ & 0.07 \\
\hline ZTG -4 & Hot spring, $5 \mathrm{~m} \mathrm{SW}$ of ZTG & 0.001 & 12.2 & 0.02 & $<0.002$ & 0.008 & 0.002 & $<0.005$ & $<0.002$ & 17.0 & $<0.1$ & $<0.05$ & 0.90 & $<0.002$ & 2.43 & 0.018 & 0.2 & $<0.002$ & $<0.1$ & 0.043 & $<0.1$ & $<0.1$ & & 0.1 & 0.16 \\
\hline ZTG-5 & Fuentes Georgines (Z-34) & 0.001 & 16.1 & 0.03 & $<0.002$ & 0.008 & 0.002 & 0.011 & 0.036 & 4.75 & $<0.1$ & $<0.05$ & 0.83 & $<0.002$ & 0.34 & 0.009 & 0.1 & 0.002 & $<1$ & 0.18 & $<0.1$ & $<0.1$ & $<0.05$ & 0.1 & 0.10 \\
\hline TG-6 & Fuentes Georgines (Z-31), lower pool & $<0.001$ & 33.6 & 0.06 & $<0.002$ & $<0.002$ & 0.003 & 0.013 & 0.004 & 18.8 & $<0.1$ & $<0.05$ & 1.41 & 0.003 & 0.68 & 0.005 & $<0.1$ & 0.003 & $<1$ & 0.23 & $<0.1$ & $<0.1$ & $<0.05$ & $<0.1$ & 0.22 \\
\hline ZTG-7 & Steam condensate, Las Fresas & $<0.001$ & $<0.1$ & $<0.01$ & $<0.002$ & $<0.002$ & $<0.002$ & 0.008 & $<0.002$ & 0.07 & $<0.1$ & $<0.05$ & $<0.01$ & $<0.002$ & 0.67 & $<0.002$ & $<0.1$ & $<0.002$ & $<0.1$ & 0.008 & $<0.1$ & $<0.1$ & $<0.05$ & $<0.1$ & $<0.01$ \\
\hline ZTG-8 & Steam condensate (ZF-38) & $<0.001$ & $<0.1$ & $<0.01$ & $<0.002$ & $<0.002$ & 0.030 & $<0.005$ & 0.005 & 0.27 & $<0.1$ & $<0.05$ & $<0.01$ & $<0.002$ & 2.90 & 0.046 & $<0.1$ & $<0.002$ & $<0.1$ & $<0.005$ & $<0.1$ & $<0.1$ & $<0.05$ & $<0.1$ & $<0.01$ \\
\hline TTG.: & Furnarc & 0.001 & 0.4 & 0.07 & $<0.002$ & $<0.002$ & 0.004 & 0.006 & 0.004 & 0.33 & $<0.1$ & $\$ 0.05$ & 0.32 & $<0.002$ & 11.7 & 0.015 & 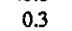 & $<0.002$ & $<0.1$ & 0.045 & & $<0.1$ & & $<0.1$ & $<0.01$ \\
\hline TG-10 & $\mathrm{Agu}$ & 0.001 & 36.3 & 0.03 & $<0.002$ & $<0.002$ & 0.002 & $<0.005$ & 0.019 & 8.43 & $<0.1$ & .05 & 74 & $<0.002$ & 0.52 & 0.009 & 0.3 & 32 & $<1$ & 0.11 & $<0.1$ & $<0.1$ & & 0.1 & $<0.01$ \\
\hline ZTG-11 & Aguas & $<0.001$ & 35.1 & 0.03 & $<0.002$ & $<0.002$ & 0.002 & $<0.005$ & 0.007 & 10.4 & $<0.1$ & $<0.05$ & 98 & $<0.002$ & 0.54 & 0.009 & 0.9 & 0.003 & $<1$ & 0.12 & $<0.1$ & $<0.1$ & $<0.05$ & $<0.1$ & 0.12 \\
\hline ZTG -19 & Hot spring (Z-17) & $<0.001$ & $<0.1$ & $<0.01$ & $<0.002$ & $<0.002$ & $<0.002$ & 0.033 & $<0.002$ & $<0.01$ & $<0.1$ & 0.24 & 0.19 & 0.018 & 0.07 & $<0.002$ & $<0.1$ & $<0.002$ & $<0.1$ & 0.073 & $<.1$ & $<0.1$ & $<0.05$ & $<0.1$ & $<0.01$ \\
\hline ZTG-23 & Steam condensate, Fumarole Negro & $\ldots$ & ... & ... & -.. & $\ldots$ & $\ldots$ & $\ldots$ & ... & ... & .. & ... & ... & -.. & 0.49 & $\ldots$ & $<0.05$ & $\ldots$ & $<0.05$ & $\ldots$ & $\ldots$ & $\ldots$ & -- & $\ldots$ & \\
\hline ZTG-25 & & מח & $<0.1$ & 0.13 & $<0.0$ & 500 & $<.0$ & $<0.0$ & $<0.0$ & 0.0 & $<0.1$ & 00 & 0.63 & $<0.0$ & 0.28 & 0.0 & $<0.05$ & $<0.0$ & 0.41 & 0.0 & 000 & $<0.1$ & $<0$. & $<0.1$ & 0.03 \\
\hline 8 & $\mathrm{H}$ & .001 & $<.1$ & $<0.01$ & $<0$ & $<$ & $<$ & 0 & $<0$ & $<0$. & $<0$ & 0.08 & 0.04 & 0.010 & 5 & $<0$ & 88 & & & & $<$ & $<0.1$ & & 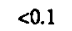 & 01 \\
\hline ZTG-30 & Make up water & 0.001 & $<0.1$ & 0.05 & $<0.001$ & $<0.002$ & $<0.002$ & 0.011 & $<0.002$ & 0.04 & $<0.1$ & $<0.01$ & 0.01 & 0.003 & 05 & $<0.002$ & 8.0 & $<0.002$ & 0.82 & 0.018 & $<0.05$ & $<0.1$ & $<0.01$ & 0.1 & $<0.01$ \\
\hline ZTG-37 & Steam condensale, Baños Los Vaho & $<0.001$ & $<0.1$ & $<0.01$ & $<0.001$ & $<0.002$ & $<0.002$ & $<0.002$ & $<0.002$ & 0.02 & $<0.1$ & $<0.01$ & $<0.01$ & $<0.002$ & $<0.05$ & $<0.002$ & 0.06 & $<0.002$ & $<0.1$ & $<0.002$ & $<0.05$ & $<0.1$ & $<0.01$ & $\infty .1$ & 0.04 \\
\hline \multicolumn{26}{|c|}{ Cold Springs } \\
\hline TG-2 & $\mathrm{C}$ & $<0.001$ & $<0.1$ & 0.02 & $<0.002$ & $<0.002$ & $<0.002$ & $<0.005$ & $<$ & $<0.01$ & $<$ & $<0.05$ & $<$ & & 6 & c & & & 0.2 & & & 1 & $<$ & 0.1 & 01 \\
\hline ( & A & .001 & 18.9 & 0.03 & $<0.002$ & $<0.002$ & $<0.002$ & $<0.005$ & 0.004 & 3.16 & $<0.1$ & 8 & 0.29 & $<0.002$ & .07 & 0.015 & 1.4 & 12 & & & & $<0.1$ & & & $<0.01$ \\
\hline ZTG-14 & Cold $s$ & .001 & $<0.1$ & 0.05 & $<0.002$ & $<0.002$ & $<0.002$ & $<0.005$ & $<0.002$ & 0.01 & $<0.1$ & $<0.05$ & $<0.01$ & 0.003 & 0.12 & $<0.002$ & 11.2 & $<0.002$ & $<0.1$ & 0.006 & $<0.1$ & $<0.1$ & $<0.05$ & $<0.1$ & $<0.01$ \\
\hline ZTG-15 & & 01 & $<0.1$ & 0.11 & $<0.002$ & $<0.002$ & $<0.002$ & 0.007 & $<0.002$ & $<0.01$ & $<0.1$ & $<0.05$ & $<0.01$ & $<0.002$ & 0.08 & 0.002 & 22.5 & $<0.002$ & $<0.1$ & 0.009 & $<0.1$ & $<0.1$ & $<0.05$ & $<0.1$ & $<0.01$ \\
\hline G-2A & $\mathbf{A}$ & i1 & $<0.1$ & 0.02 & $<0.001$ & $<0.002$ & $<0.002$ & $<0.0$ & 0.006 & 0.05 & & $<0.01$ & 0.02 & $<0.002$ & 0.05 & & 8.7 & $<0.002$ & & 0.014 & $<0.05$ & $<0.1$ & $<0.01$ & $<0.1$ & $<0.01$ \\
\hline & & & 0 & & & & $<0.002$ & $<0$. & $<0$ & & & & & & & & 265 & & & & & $<0.1$ & & 0.1 & 0.01 \\
\hline & & & $<0.1$ & 0.02 & $<0$ & & $<0$ & $<0.0$ & & & $<$ & & $<.01$ & & 06 & $<0$ & 9.4 & & & & & & & & 0.01 \\
\hline ZTG-38 & Col & 01 & $<0.1$ & $<0.01$ & 01 & 12 & $<0.002$ & $<0.002$ & $<0.002$ & 0. & $<0$ & $<0.01$ & 0.02 & $<0$. & 0.06 & & 9.9 & 2 & 0.08 & $f$ & $<0.05$ & $<0.1$ & $<0.01$ & 0.1 & 0.03 \\
\hline ZTG -40 & Cold spring off cliff on Río Zarmaca & $<0.001$ & $<0.1$ & $<0.01$ & $<0.001$ & $<0.002$ & $<0.002$ & 0.005 & $<0.002$ & 0.02 & $<0.1$ & $<0.01$ & $<0.01$ & 0.004 & 0.07 & 0.002 & 5.41 & $<0.002$ & 0.09 & 0.010 & $<0.05$ & $<0.1$ & $<0.01$ & $<0.1$ & $<0.01$ \\
\hline \multicolumn{26}{|c|}{ Geothermal and other Wells } \\
\hline ZTG-13 & Downhole at ZC & & 0.5 & 0.02 & $<0.0$ & $<0.0$ & & & $<0.002$ & & & & & 0.01 & 1.96 & 0.0 & & & & & & 1 & $<0.05$ & 0.1 & $<0.01$ \\
\hline ZTG & & & 0.69 & $<0.01$ & & & & & & & & & $<0$ & & & & 0.75 & & & & & & $<0.05$ & 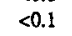 & $<0.01$ \\
\hline & $\mathrm{D}$ & & $<0.1$ & 0.13 & & & & & $<0$ & & & 2.73 & 0 & & 55 & & $<0.1$ & $<$ & $<$ & & $<$ & $<0.1$ & .90 & 1 & $<0.01$ \\
\hline $2 \pi$ & & & $<0.1$ & & $<0$. & $<0.0$ & $<0$. & 0.007 & $<0.002$ & $<0.01$ & $<0.1$ & & 0.54 & 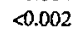 & 0.28 & $<0.002$ & 11 & & 0.27 & & $<0.05$ & & $<0.01$ & 0.1 & 0.01 \\
\hline ZTG & & $<0.001$ & 0.27 & 0.03 & $<0.001$ & $<0.002$ & $<0.002$ & & $<0.002$ & $<0.01$ & $<0.1$ & 277 & 0.01 & 0.8 & 0.49 & 0.003 & $<0.1$ & $<0.002$ & $<0.2$ & & 0.18 & $<0.1$ & 0.77 & 0.1 & 0.01 \\
\hline ZTG & Stre & 1 & $<0.1$ & 0.08 & $<0,001$ & $<0$. & & & & & $<0.1$ & 0.16 & 0.02 & $<0.0<-2$ & 95 & 0. & 0.43 & 0. & $<0.1$ & & $<0.05$ & $<0.1$ & 2.32 & .1 & 05 \\
\hline ZTC & & & $<0.1$ & 0.03 & & 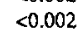 & & $<0$ & $<0.8<-8$ & & $<$ & $<0$ & & & & & & & & $<0.002$ & & & & 1 & 02 \\
\hline & & & 0 & & & & & & & & & & & & & & & & & & & & & & 00 \\
\hline & $\mathrm{H}$ & & $<0.1$ & 0.06 & & & $<0.002$ & 0. & 0. & 6.50 & 4 & & & & & & & & & & & & & & \\
\hline ZTG & Weir & $<0.001$ & 0.46 & 0.03 & $<0.001$ & $<0.002$ & $<0.002$ & 0.6 & $<0.002$ & 0.3 & $<0.1$ & 1.7 & 0.02 & 0.0 & & $<0$. & $<0.1$ & $<0.002$ & $<0$ & 0.9 & 0.53 & $<0.1$ & 0.58 & $<0.1$ & 0.02 \\
\hline ZTG.39a & ZP- $6 \mathrm{C}$ & $<0.001$ & 0.18 & $<0.01$ & $<0.001$ & $<0.002$ & $<0.002$ & 0.8 & $<0.002$ & $<0.02$ & $<0.1$ & 2.09 & 0.02 & 0.019 & 0.37 & $<0.002$ & $<0.1$ & $<0.002$ & $<0.2$ & 0.032 & 0.63 & $<0.1$ & 0.56 & $<0.1$ & 0.07 \\
\hline ZTG-4la & Weirbox at $Z C Q-3$ & $<0.001$ & 0.59 & 0.01 & $<0.001$ & $<0.002$ & $<0.002$ & 0.93 & $<0.002$ & 0.05 & $<0.1$ & 2.01 & $<0.01$ & 0.034 & 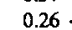 & 0.00 & $<0.1$ & $<0.002$ & $<0.2$ & 1.37 & 0.52 & $<0.1$ & 0.23 & $<0.1$ & 0.02 \\
\hline
\end{tabular}

a Chemistry corrected for flashing according to formation temperatures (see Table $\mathrm{I}$. 


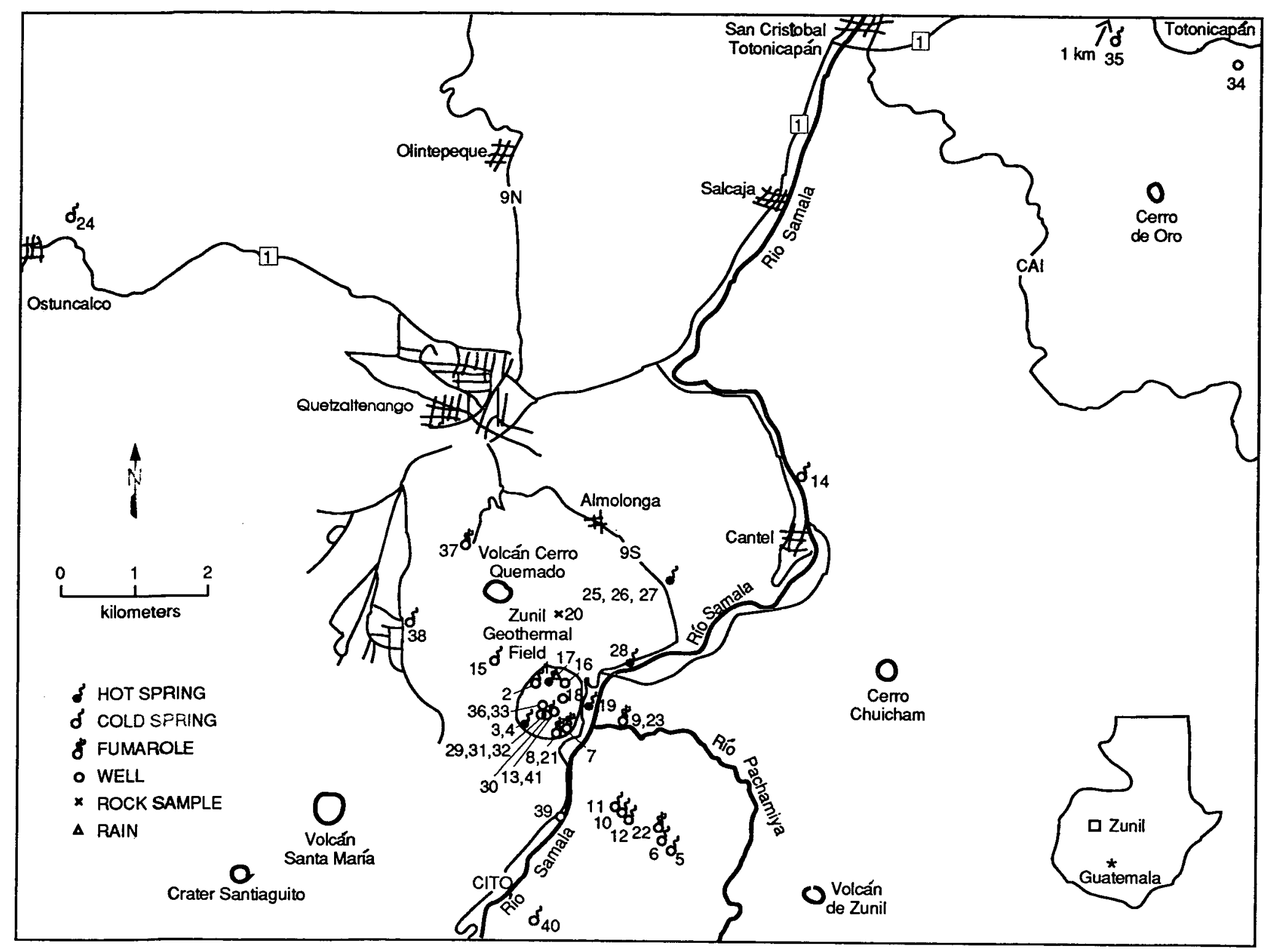

Fig. 15. Location map of Zunil-Quetzaltenango region, Guatemala, showing sample locations. 


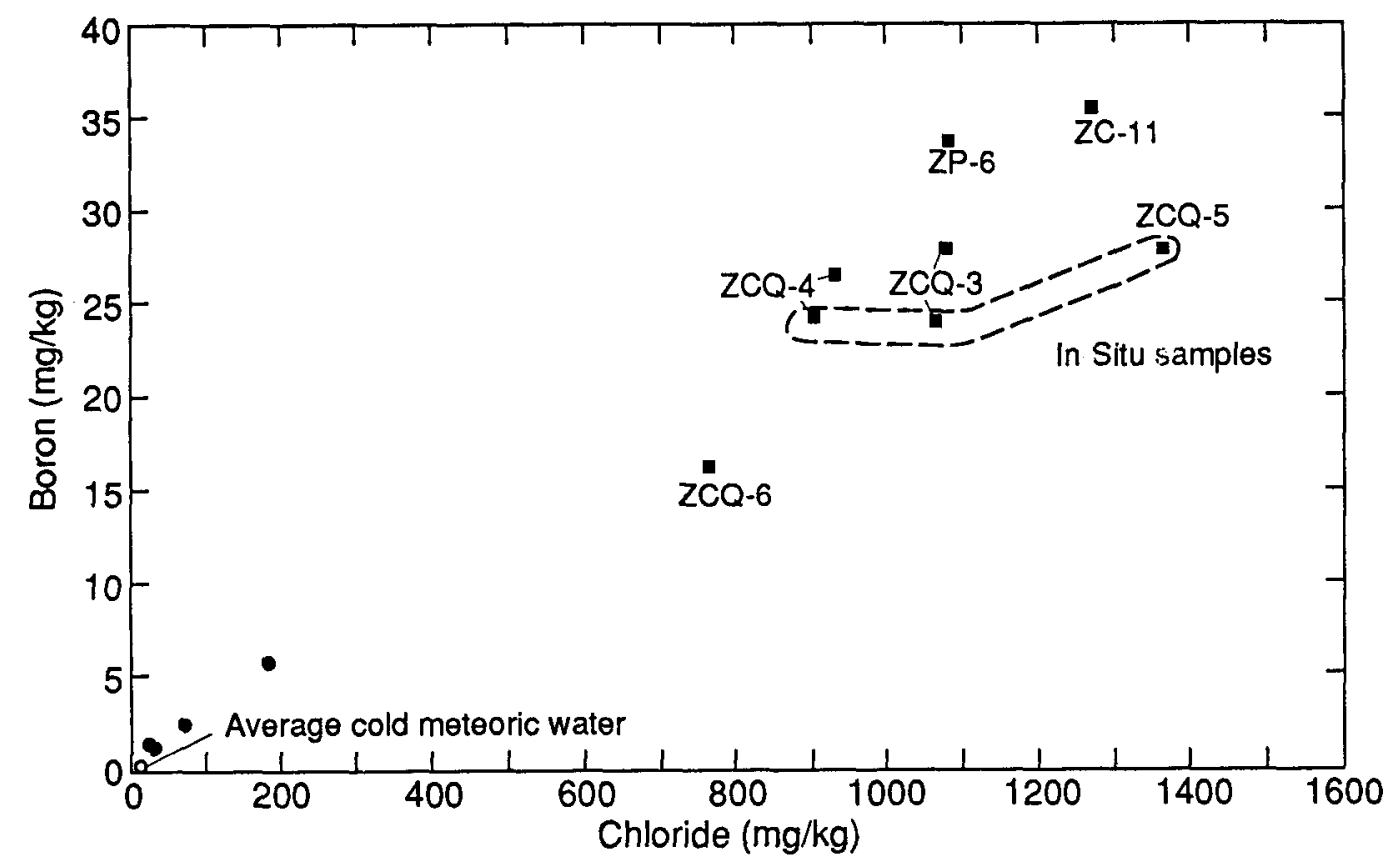

Fig. 16. Boron versus chloride for reservoir fluids, hot springs, and average values of the cold waters sampled, Zunil geothermal field, Guatemala. All data are flash-corrected where appropriate. Well and spring numbers can be found in Table I. $\mathrm{O}=$ average cold springs; $O=$ hot springs; $\boldsymbol{\square}=$ well samples.

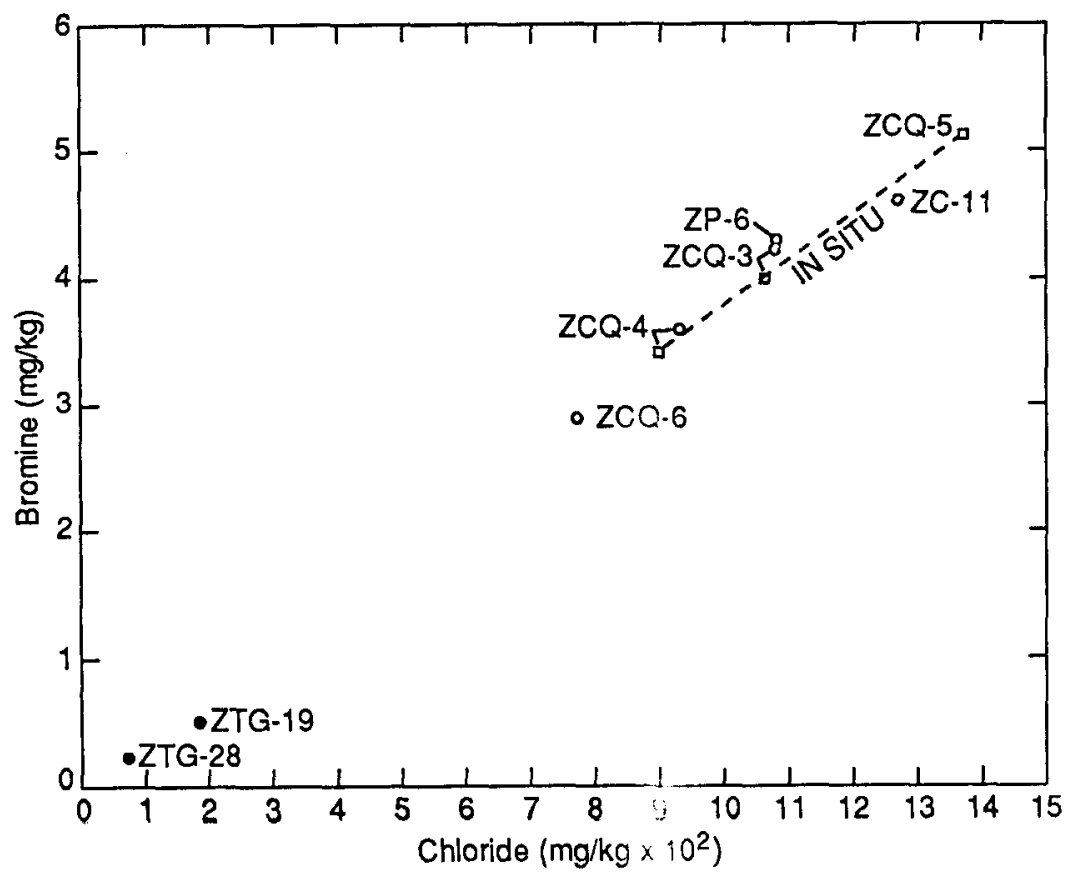

Fig. 17. Bromine versus chloride for reservoir fluids and hot springs waters sampled, ZunilQuetzaltenango region, Guatemala. All data are flash-corrected where appropriate. Well and spring numbers can be found in Table I. $O=$ well samples, weirboxes; $\square=$ well samples in situ; $\bigcirc=$ hot springs. 


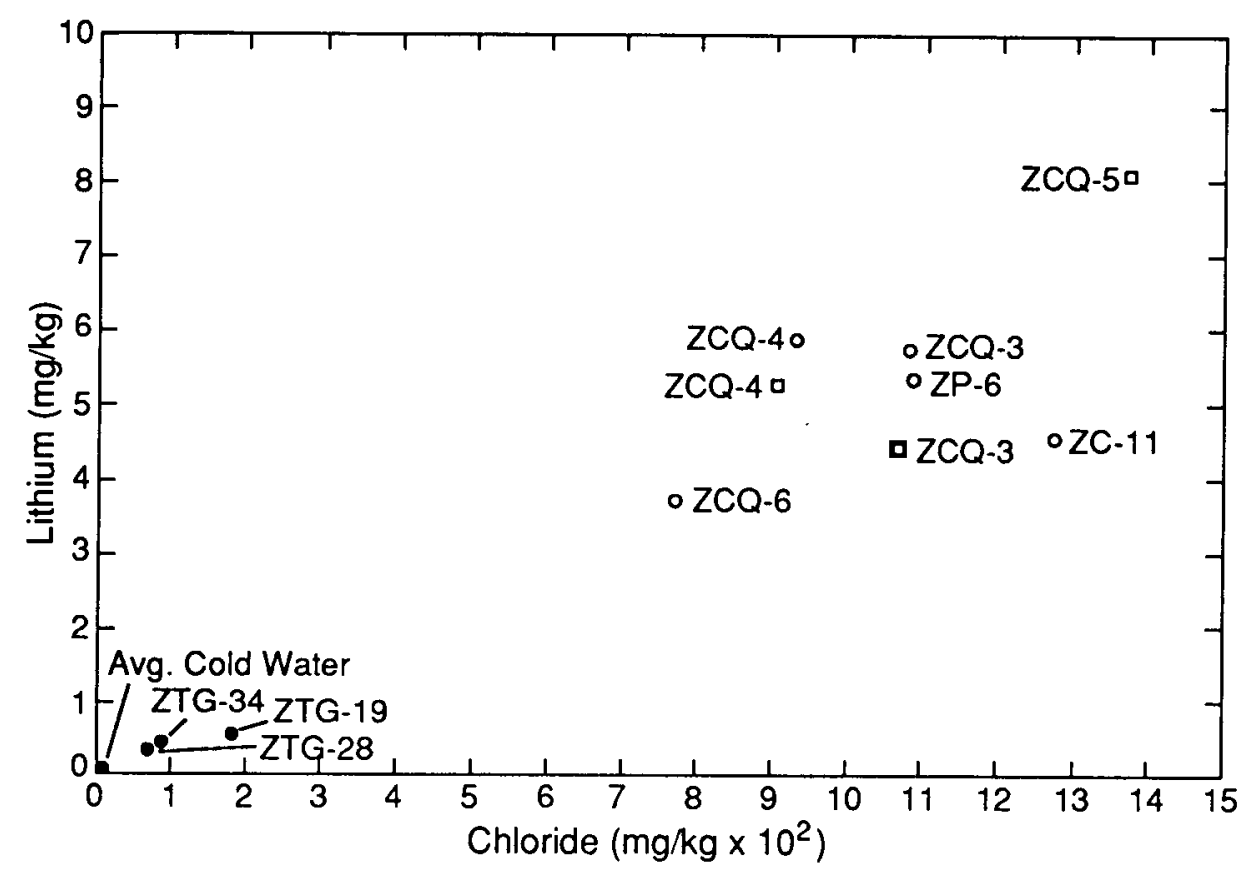

Fig. 18. Lithium versus chloride for reservoir fluids, hot springs, and average values of the cold waters sampled, Zunil-Quetzaltenango region, Guatemala. All data are flash-corrected where appropriate. Well and spring numbers can be found in Table I. $\mathrm{O}=$ well waters, weirbox; $\mathbf{\theta}=$ hot springs; $\square=$ well waters in situ.

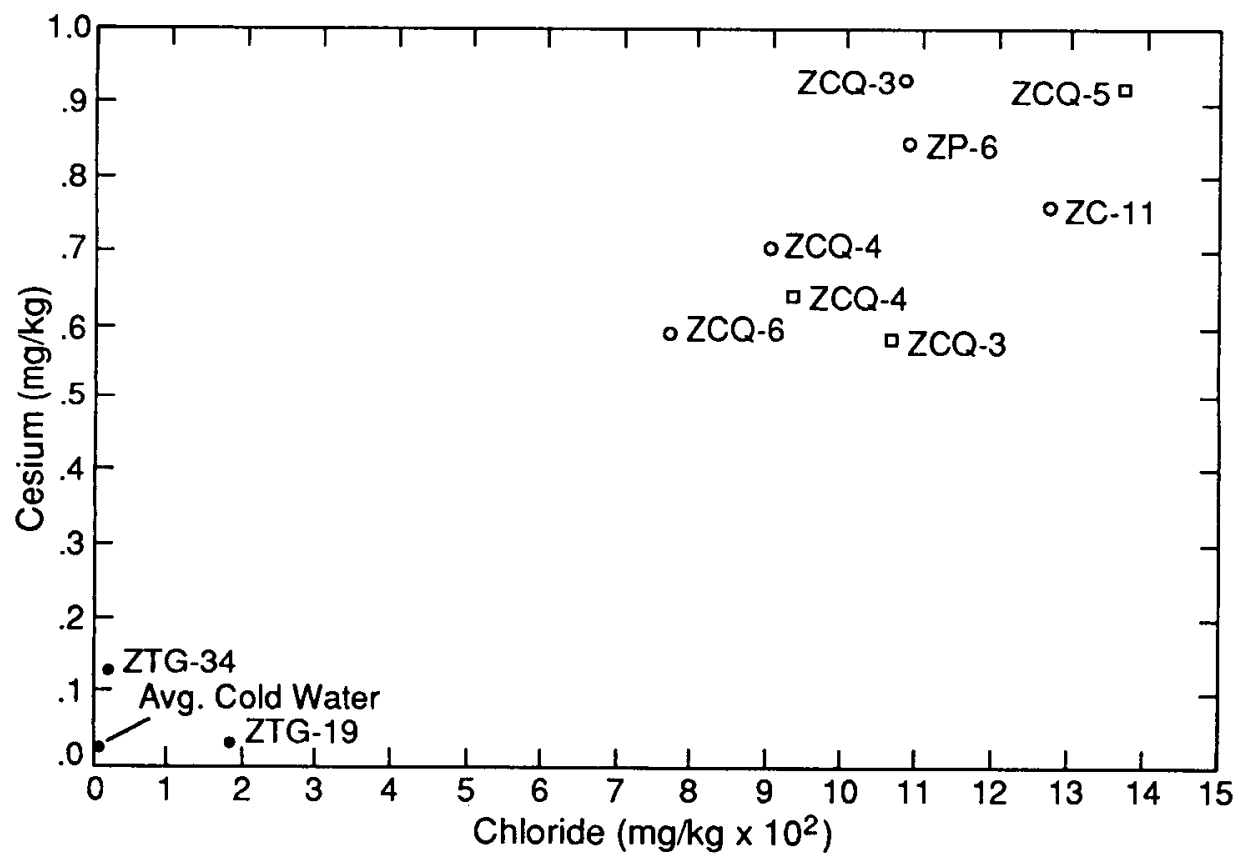

Fig. 19. Cesium versus chloride for reservoir fluids, hot springs, and average values of the cold waters sampled, Zunil-Quetzaltenango region, Guatemala. All data are flash-corrected where appropriate. Well and spring numbers can be found in Table I. $O$ =springs; $\mathrm{O}=$ wells, weirbox; $\square=$ well samples in situ. 
that a thermal plume originates from beneath the zone of acid-sulfate springs to the east of the production wells. This figure suggests that the Zunil II area might be a better geothermal prospect than Zunil I. Giggenbach (1988) proposed a similar type of model.

\section{STABLE ISOTOPES}

Figure 21 and Table $\mathrm{V}$ present stable isotope variations of the Zunil area fluids. With the exception of the acid-sulfate waters, all cold and hot springs plot on or near the isotopic composition of meteoric waters for the area and have a $\delta D$ range of -73 to -87 . The in situ fluid samples have a very restricted $\delta D$ range of -76.6 to -78.2 compared to flash-corrected reservoir samples and probably represent the isotopic composition of the unflashed reservoir fluid. The rainwater sample is not typical of the local groundwaters having a $\delta D$ of -17.5 and $\delta^{18} 0$ of -3.04 . This probably represents a storm of unusual composition.

The trio of in situ well samples is shifted to the right of the world meteoric water line as are the weirbox samples indicating that significant oxygen-18 enrichurient has occurred between water and rock in a high-temperature environment. Oxygen-18 shifts of $2 \%$ o to $12 \%$ are characteristic of geothermal reservoirs $>200^{\circ} \mathrm{C}$ and the $3 \%$ shift of the in situ samples is quite typical. According to the isotopic composition of a limited number of cold springs and wells, the mountains to the north and east of the field are logical recharge areas for the geothermal reservoir.

\section{CHEMICAL GEOTHERMOMETRY}

Table VI lists calculated subsurface equilibration temperatures for well waters and bicarbonate-rich hot spring waters. Measured temperatures in the feed zones of the wells logged by LANL range from $255^{\circ} \mathrm{C}$ to $278^{\circ} \mathrm{C}$. There is reasonably good agreement between measured temperatures and quartzconductive, $\mathrm{Na} / \mathrm{K}$, and $\mathrm{Na}-\mathrm{K}-\mathrm{Ca}$ geothermometers. Temperatures calculated by the $\mathrm{Na} / \mathrm{Li}$ and $\mathrm{K} / \mathrm{Mg}$ geothermometers are consistently lower than the measured temperatures. From the K-Mg relation and other arguments, Giggenbach (1988) suggests that the fluids have reequilibrated to lower temperatures from their original temperatures. Differences in chemistry between in situ samples and weirbox samples for a given well and the resulting differences in geothermometer estimates probably indicate that the wells produce fluids from several horizons of chemistry slightly different from that reflected by the single feed zones sampled in situ. The unusually dilute chemistry of well ZCQ-6 and the relatively low geothermometer estimates based on its chemistry may indicate that this well has low permeability and is an excess enthalpy well. 
TABLE IV. Gas Analyses of Well and Fumarole Samples, Zunil, Guatemala (all values in vol\% dry gas)

\begin{tabular}{|c|c|c|c|c|c|c|c|c|c|c|c|c|}
\hline Sample & Date & Description & $\mathrm{CO}_{2}$ & $\mathrm{H}_{2} \mathrm{~S}$ & $\mathrm{NH}_{3}$ & Ar & $\mathrm{N}_{2}$ & $\mathrm{O}_{2}$ & $\mathrm{CH}_{4}$ & $\mathrm{H}_{2}$ & $\mathrm{He}$ & Total \\
\hline $2 \Gamma_{G}-21^{b}$ & $02 / 27 / 89$ & Fumarole Azufalito & 96.99 & 1.23 & 0 & 0.0075 & 1.65 & 0.0018 & 0.049 & 0.016 & 0.0018 & 99.94 \\
\hline ZTG-22 & $02 / 28 / 89$ & Fumarole near Georgina & 87.74 & 9.48 & 0 & 0.0337 & 2.58 & 0.0081 & 0.043 & 0.068 & 0.0203 & 99.97 \\
\hline ZTG-23 & $02 / 28 / 89$ & Fumarole Negro & 93.93 & 2.78 & 0 & 0.0510 & 2.67 & 0.0398 & 0.085 & 0.391 & 0.0178 & 99.87 \\
\hline ZTG-31 & $12 / 11 / 89$ & Well ZC-11, mini-separator & 97.43 & 0.59 & 0.19 & 0.0167 & 1.43 & 0.0 & 0.025 & 0.372 & 0.0073 & 100.06 \\
\hline ZTG-33 & $12 / 11 / 89$ & Well ZCQ-4 downhole@ @ $900 \mathrm{~m}$ & 82.09 & $<0.05$ & $\ldots$ & 0.13 & 16.84 & 0.0 & $<0.05$ & 0.58 & $<0.01$ & 98.93 \\
\hline
\end{tabular}

Analyses by P. Trujillo, LANL.

Analysis for $2 T \mathrm{TG}-21$ includes 0.0051 vol\% $\mathrm{C}_{2} \mathrm{H}_{6}$.

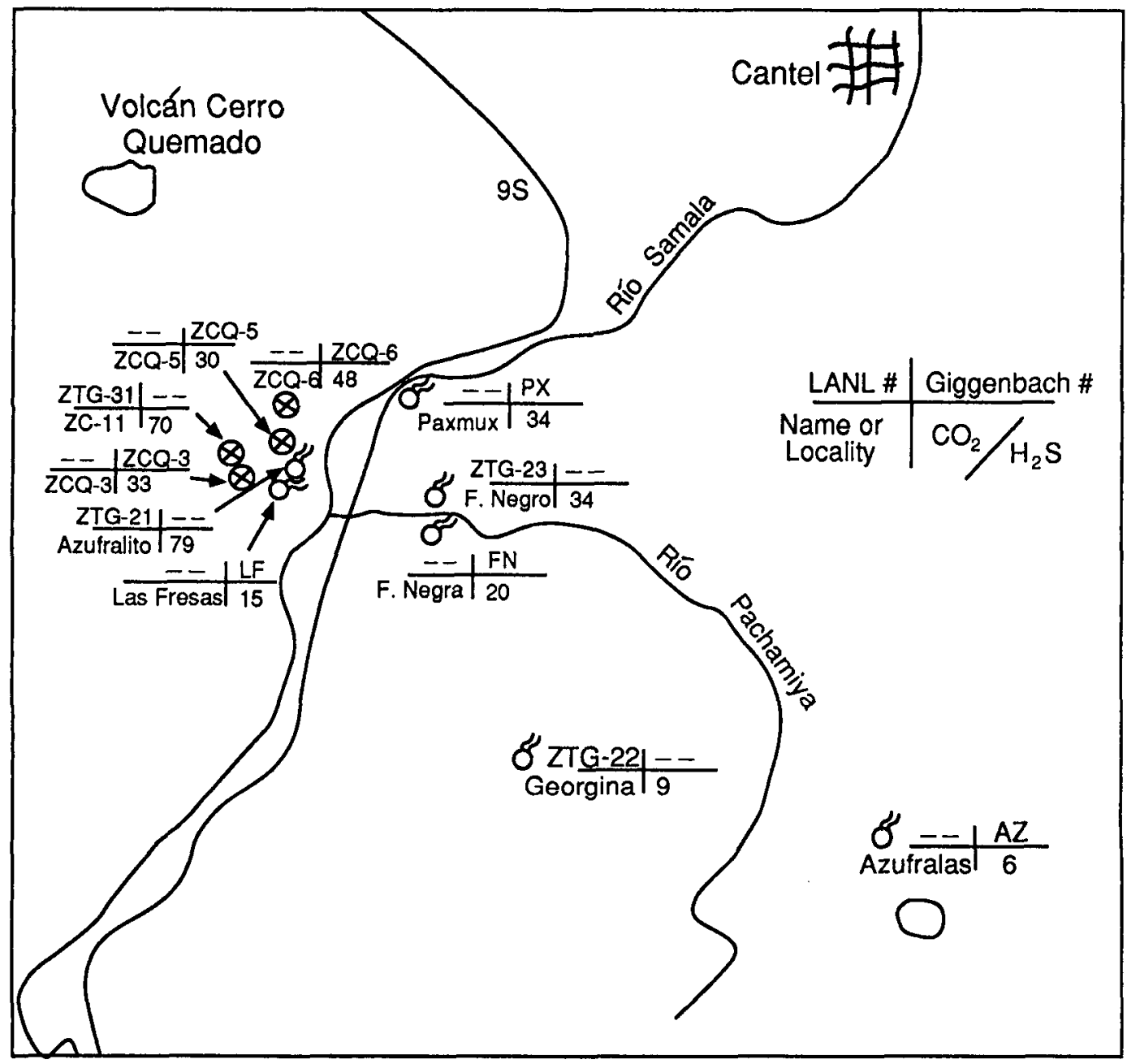

Fig. 20. Map showing $\mathrm{CO}_{2} / \mathrm{H}_{2} \mathrm{~S}$ for wells and fumaroles in the Zunil-Quetzaltenango region, Guatemala. 
that a thermal plume originates from beneath the zone of acid-sulfate springs to the east of the production wells. This figure suggests that the Zunil II area might be a better geothermal prospect than Zunil I. Giggenbach (1988) proposed a similar type of model.

\section{STABLE ISOTOPES}

Figure 21 and Table V present stable isotope variations of the Zunil area fluids. With the exception of the acid-sulfate waters, all cold and hot springs plot on or near the isotopic composition of meteoric waters for the area and have a $\delta \mathrm{D}$ range of -73 to -87 . The in situ fluid samples have a very restricted $\delta \mathrm{D}$ range of -76.6 to -78.2 compared to flash-corrected reservoir samples and probably represent the isotopic composition of the unflashed reservoir fluid. The rainwater sample is not typical of the local groundwaters having a $\delta D$ of -17.5 and $\delta^{18} 0$ of -3.04 . This probably represents a storm of unusual composition.

The trio of in situ well samples is shifted to the right of the world meteoric water line as are the weirbox samples indicating that significant oxygen-18 enrichment has occurred between water and rock in a high-temperature environment. Oxygen-18 shifts of $2 \%$ to $12 \%$ are characteristic of geothermal reservoirs $>200^{\circ} \mathrm{C}$ and the $3 \%$ shift of the in situ samples is quite typical. According to the isotopic composition of a limited number of cold springs and wells, the mountains to the north and east of the field are logical recharge areas for the geothermal reservoir.

\section{CHEMICAL GEOTHERMOMETRY}

Table VI lists calculated subsurface equilibration temperatures for well waters and bicarbonate-rich hot spring waters. Measured temperatures in the feed zones of the wells logged by LANL range from $255^{\circ} \mathrm{C}$ to $278^{\circ} \mathrm{C}$. There is reasonably good agreement between measured temperatures and quartzconductive, $\mathrm{Na} / \mathrm{K}$, and $\mathrm{Na}-\mathrm{K}-\mathrm{Ca}$ geothermometers. Temperatures calculated by the $\mathrm{Na} / \mathrm{Li}$ and $\mathrm{K} / \mathrm{Mg}$ geothermometers are consistently lower than the measured temperatures. From the $\mathrm{K}-\mathrm{Mg}$ relation and other arguments, Giggenbach (1988) suggests that the fluids have reequilibrated to lower temperatures from their original temperatures. Differences in chemistry between in situ samples and weirbox samples for a given well and the resulting differences in geothermometer estimates probably indicate that the wells produce fluids from several horizons of chemistry slightly different from that reflected by the single feed zones sampled in situ. The unusually dilute chemistry of well ZCQ-6 and the relatively low geothermometer estimates based on its chemistry may indicate that this well has low permeability and is an excess enthalpy well. 
TABLE V. Isotope Data for Geothermal Wells, Hot/Cold Springs and Fumaroles in the ZunilQuetzaltenango Region, Guatemala

\begin{tabular}{|c|c|c|c|c|c|}
\hline Sample & Description & Date & $\begin{array}{r}\delta \mathrm{D} \\
(\% 0) \\
\end{array}$ & $\begin{array}{l}\delta^{18} \mathrm{O} \\
(\%)\end{array}$ & $\begin{array}{c}\text { Tritium } \\
\text { (T.U.) }\end{array}$ \\
\hline ZTG-1 & Warm spring (Z-58), $100 \mathrm{~m}$ W of ZCQ-5 & $10 / 26 / 88$ & -87.2 & -12.19 & 2.9 \\
\hline ZTG-2 & Cold spring (Z-47B), $100 \mathrm{~m} \mathrm{S10E}$ of ZTG-1 & $10 / 26 / 88$ & -87.6 & -12.06 & 1.71 \\
\hline ZTG-3 & Hot spring (Z-47), from iron pipe & $10 / 27 / 88$ & -84.0 & -11.47 & 3.47 \\
\hline ZTG-4 & Hot spring, $5 \mathrm{~m} \mathrm{SW}$ of ZTG-3 & $10 / 27 / 88$ & -81.5 & -11.42 & -- \\
\hline ZTG-5 & Fuentes Georgines $(Z-34)$ & $10 / 28 / 88$ & -79.4 & -10.58 & 6.23 \\
\hline ZTG-6 & Fuentes Georgines (Z-31), lower pool & $10 / 28 / 88$ & -78.4 & -9.40 & -- \\
\hline ZTG-9 & Fumarole Negro (ZF-36) & $10 / 30 / 88$ & -64.8 & -7.18 & -- \\
\hline ZTG-10 & Aguas Amargas (Z-19) & $10 / 30 / 88$ & 78.6 & -9.57 & --- \\
\hline ZTG-11 & Aguas Amargas (Z-19), $20 \mathrm{~m} \mathrm{NNW}$ of ZTG-10 & $10 / 30 / 88$ & -74.8 & -9.04 & 5.24 \\
\hline ZTG-12 & Aguas Amargas (Z-19A), cold spring & $10 / 30 / 88$ & -74.4 & -11.03 & -- \\
\hline ZTG-13 & Downhole at ZCQ-3 (671 m) & $10 / 31 / 88$ & 76.7 & -7.92 & 5.25 \\
\hline ZTG-14 & Cold spring (Z-42) & $10 / 31 / 88$ & -80.1 & -11.12 & $-\cdots$ \\
\hline ZTG-15 & Cold spring, Chicua & $11 / 01 / 88$ & -86.7 & -11.86 & 6.35 \\
\hline ZTG-16 & Weirbox at ZCQ-6 & $11 / 01 / 88$ & $-72.3^{\mathrm{a}}$ & $-7.40^{\mathrm{a}}$ & 0.32 \\
\hline ZTG-17 & Rainwater at $\mathrm{ZCQ}-1$ & $11 / 02 / 88$ & -17.5 & -3.04 & 3.89 \\
\hline ZTG-18 & Downhole at ZCQ-5 (775 m) & $11 / 02 / 88$ & -78.2 & -8.14 & 14.8 \\
\hline ZTG-19 & Hot spring (Z-17) & $11 / 03 / 88$ & -83.0 & -10.94 & 0.16 \\
\hline ZTG-23 & Steam condensate, Fumarole Negro & $02 / 28 / 89$ & -86.5 & -12.75 & -- \\
\hline ZTG-24 & Agua Tibia, $1.5 \mathrm{~km}$ NE of Ostuncalco & $12 / 06 / 89$ & -81.7 & -11.43 & -- \\
\hline ZTG-25 & Baños Sulfurosos El Recreo & $12 / 07 / 89$ & -81.8 & -11.23 & -- \\
\hline ZTG-26 & $3 \mathrm{~m} \mathrm{E}$. of ZTG- 22 cold spring & $12 / 07 / 89$ & -78.5 & -10.35 & -- \\
\hline ZTG-27 & Baños Sulfurosos well & $12 / 07 / 89$ & -82.0 & -11.24 & -- \\
\hline ZTG-28 & Hot spring on NW bank of Río Samala & $12 / 07 / 89$ & -80.3 & -11.02 & -- \\
\hline ZTG-29 & $\mathrm{ZC}-11$ direct use well from weirbox & $12 / 08 / 89$ & $-61.7^{a}$ & $-6.44^{a}$ & --- \\
\hline ZTG-30 & Make up water for $\mathrm{ZC}-11$, warm spring & $12 / 08 / 89$ & -88.3 & -12.57 & --- \\
\hline ZTG-31 & Steam side of separator at $\mathrm{ZC}-11$ & $12 / 09 / 89$ & -74.1 & -9.42 & --- \\
\hline ZTG-32 & Total flow from separator at $\mathrm{ZC}-11$ & $12 / 09 / 89$ & -77.8 & -9.45 & --- \\
\hline ZTG-33 & Downhole at $\mathrm{ZCQ}-4(900 \mathrm{~m})$ & $12 / 11 / 89$ & -77.1 & -8.22 & 0.02 \\
\hline ZTG-34 & Hot well $0.5 \mathrm{~km} \mathrm{~S}$ of Totonicapán & $12 / 11 / 89$ & -77.3 & -10.38 & --- \\
\hline ZTG-35 & Cold spring $0.7 \mathrm{~km} \mathrm{~W}$ of Totonicapán & $12 / 11 / 89$ & -77.3 & -9.94 & --- \\
\hline ZTG-36 & Weirbox at ZCQ-4 & $12 / 11 / 89$ & $-78.9^{\mathfrak{a}}$ & $-7.94^{\mathrm{a}}$ & 0.06 \\
\hline ZTG-37 & Baños Los V ahos, steam condensate & $12 / 12 / 89$ & -82.0 & -11.24 & -- \\
\hline ZTG-38 & Cold spring (Z-73) & $12 / 12 / 89$ & -84.4 & -11.56 & --- \\
\hline ZTG-39 & ZP- 6 exploration well & $12 / 12 / 89$ & -74.8 & -7.40 & -- \\
\hline ZTG-40 & Cold spring off cliff above Río Zarmaca & $12 / 12 / 89$ & -75.8 & -10.82 & $-\cdots$ \\
\hline ZTG-41 & Weirbox at ZCQ-3 & $12 / 12 / 89$ & $-76.8^{\mathrm{a}}$ & $-7.93^{\mathrm{a}}$ & 0.11 \\
\hline
\end{tabular}

${ }^{a}$ Isotopes corrected for flashing according to formation temperatures (see Table I). 


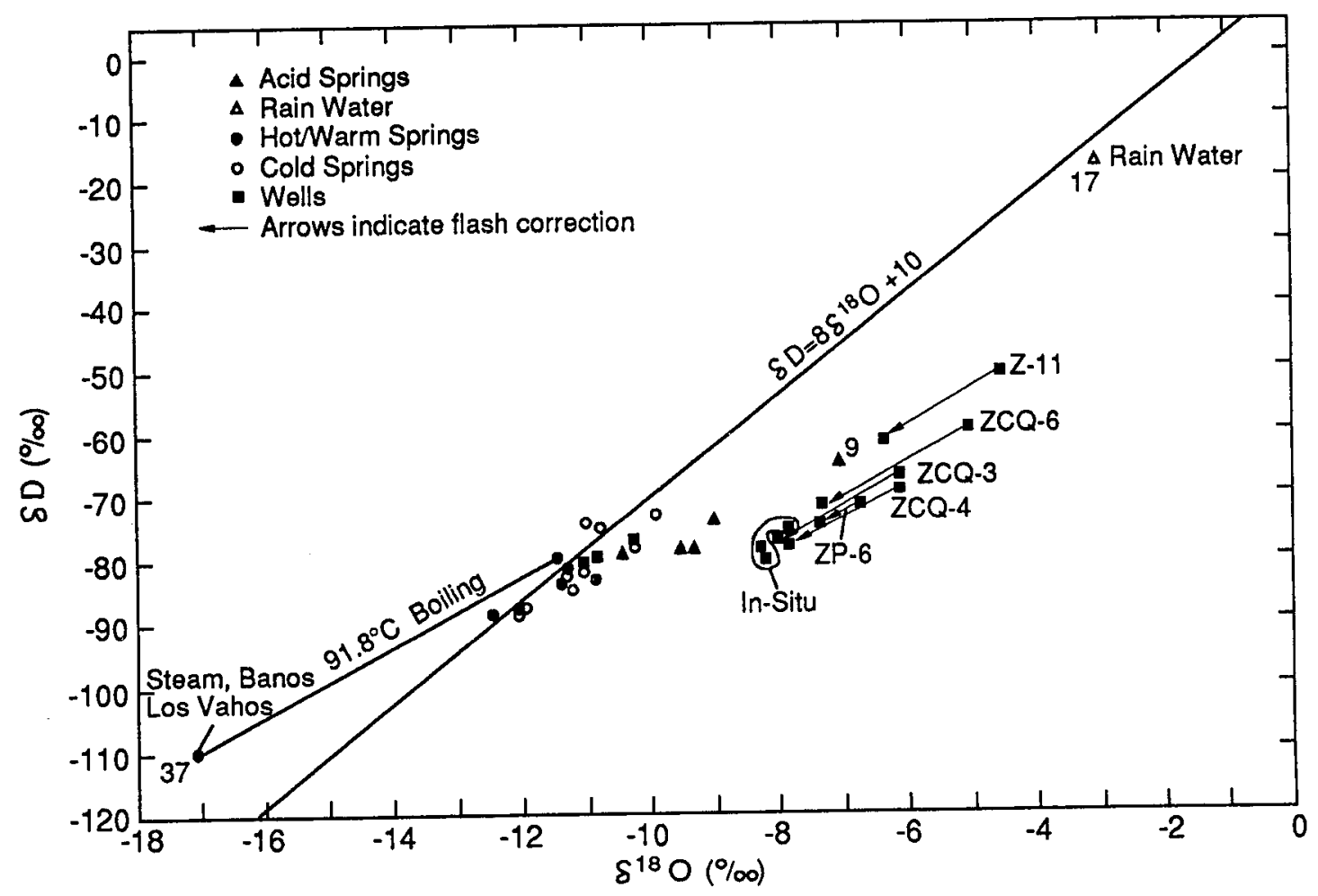

Fig. 21. Plot of $\delta D$ versus $\delta^{18} \mathrm{O}$ for thermal and nonthermal waters of Zunil-Quetzaltenango region, Guatemala.

TABLE VI. Calculated "Reservoir" Temperatures Based on Several Chemical Geothermometers

\begin{tabular}{|c|c|c|c|c|c|c|c|c|c|c|c|c|}
\hline \multirow[b]{2}{*}{ Sample } & \multirow[b]{2}{*}{ Description } & \multirow[b]{2}{*}{$\begin{array}{c}\text { Temp. } \\
\left({ }^{\circ} \mathrm{C}\right) \\
\end{array}$} & \multirow[b]{2}{*}{$\begin{array}{c}\mathrm{Cl} \\
(\mathrm{mg} / \mathrm{kg}) \\
\end{array}$} & \multirow{2}{*}{$\begin{array}{c}\text { Total } \\
\mathrm{HCO}_{3} \\
\text { (mg/kg) } \\
\end{array}$} & \multicolumn{2}{|c|}{ Silice ${ }^{b}$} & \multirow[b]{2}{*}{$\underline{\mathrm{Na} / \mathrm{K}^{\mathrm{b}}}$} & \multicolumn{3}{|c|}{$\mathrm{Na}-\mathrm{K}-\mathrm{Ca}_{\mathrm{a}}^{\mathrm{b}}$} & \multirow[b]{2}{*}{$\mathrm{Na} / \mathrm{Li}^{\mathrm{C}}$} & \multirow[b]{2}{*}{$\underline{\mathrm{K} / \mathrm{Mg}^{\mathrm{d}}}$} \\
\hline & & & & & Chal. & $Q z z-C$ & & $\beta=1 / 3$ & $\beta=4 / 3$ & Mg-Corr. & & \\
\hline \multicolumn{13}{|c|}{ Geothermal Wells } \\
\hline$\overline{Z T G-13}$ & $\mathrm{ZCQ}-3$; in situ & 258 & 1065 & 62 & 235 & 245 & 277 & 258 & - & - & 221 & \\
\hline ZTG-41 & $\mathrm{ZCQ}-3$; weirbox & 258 & $1081^{e}$ & 37 & 253 & 259 & 281 & 264 & - & - & & 251 \\
\hline ZTG-33 & $\mathrm{ZCQ}-4$; in situ & 258 & 903 & 54 & 259 & 264 & 278 & 253 & - & - & 248 & 217 \\
\hline ZTG-36 & ZCQ-4; weirbox & 258 & $931^{e}$ & 59 & 214 & 227 & 258 & 239 & - & - & 255 & \\
\hline ZTG-18 & $\mathrm{ZCQ}-5$; in situ & 255 & 1367 & 50 & 238 & 247 & 260 & 242 & $\rightarrow$ & - & 266 & - \\
\hline ZTG-16 & ZCQ-6; weirbox & 278 & $768^{e}$ & 120 & 190 & 207 & 280 & 259 & - & - & 248 & 197 \\
\hline ZTG-29 & ZC-11; weirbox & 255 & $1269^{e}$ & 61 & 199 & 215 & 205 & 205 & - & - & 200 & 212 \\
\hline ZTG-39 & ZP-6 exploration well & 90.4 & $1084^{\mathrm{e}}$ & 44 & 209 & 223 & 146 & 152 & - & - & 222 & 163 \\
\hline ZTG-27 & Baños Sulforosos Well & 45.4 & 27.8 & 231 & 147 & 170 & 222 & - & 95 & 43 & 104 & 66 \\
\hline ZTG-34 & Well near Totonicapán & 46.0 & 23.5 & 160 & 117 & 143 & 237 & 183 & - & 99 & 222 & 85 \\
\hline \multicolumn{13}{|c|}{ Warm/Hot Springs } \\
\hline ZTG-1 & Spring near ZCQ-5 & 28.8 & 4 & 168 & 109 & 136 & 336 & - & 54 & - & 91 & 46 \\
\hline ZTG-19 & Spring Z-17 & 74.4 & 186 & 665 & 156 & 178 & 219 & 187 & $\ldots$ & "cool" & 108 & 78 \\
\hline ZTG-25 & Spring, Baños Sulfurosos & 41.3 & 24 & 193 & 142 & 166 & 219 & - & 87 & 44 & 97 & 61 \\
\hline ZTG-28 & Spring, Río Samala & 61.4 & 71 & 210 & 35 & 67 & 236 & 189 & - & 31 & 131 & 77 \\
\hline ZTG-30 & Spring near ZC-11 & 30.5 & 5 & 136 & 252 & 259 & 283 & - & 62 & "cool" & 108 & 47 \\
\hline
\end{tabular}

a Formation temperatures are listed where known.

b Equations of Fournier (1981).

c Fouillac and Michard (1981).

d Giggenbach et al. (1986b).

e Flash-corrected values assuming temperature of flashing is $93.5^{\circ} \mathrm{C}$. 
Samala is composed primarily of much older water ( 0.16 T.U.). Four tritium samples of Zunil production well waters have trituim values of 0.02 to 0.32 indicating they are also primarily composed of "old" water. Assuming that the Zunil reservoir is well mixed, the maximum mean age of the deep well water ranges from 500 to 7500 years (Goff et al. 1987b; Person and Truesdell 1978).

TABLE VII. Calculated "Reservoir" Temperatures Based on Gas Geothermometers

\begin{tabular}{|c|c|c|c|c|c|c|c|}
\hline \multirow[b]{2}{*}{ Field } & \multirow[b]{2}{*}{ Site } & \multirow[b]{2}{*}{ Date } & \multirow{2}{*}{$\begin{array}{l}\text { Temp } \\
\text { Collection }\end{array}$} & \multirow[b]{2}{*}{$\mathrm{CO}_{2}$} & \multirow[b]{2}{*}{$\mathrm{H}_{2} \mathrm{~S}$} & \multicolumn{2}{|c|}{ Geothermometers } \\
\hline & & & & & & $\operatorname{tgas}^{\mathrm{a}}$ & $\mathrm{tCO}_{2}-\mathrm{CH}_{4} \mathrm{~b}$ \\
\hline ZTG-21 & Fumarole Azufalito & $02 / 27 / 89$ & 92.8 & 96.99 & 1.23 & 214 & 275 \\
\hline ZTG-22 & Fumarole near Georgina & $02 / 28 / 89$ & 94 & 87.74 & 9.48 & 213 & 276 \\
\hline ZTG-23 & Fumarole Negro & $02 / 28 / 89$ & 94 & 93.93 & 2.78 & 234 & 254 \\
\hline ZTG-31 & Well ZC-11, mini-separator & $12 / 11 / 89$ & 164.5 & 97.43 & 0.59 & 222 & 299 \\
\hline
\end{tabular}

a D'Amore and Panichi 1980.

b Norman and Bernhart 1981.

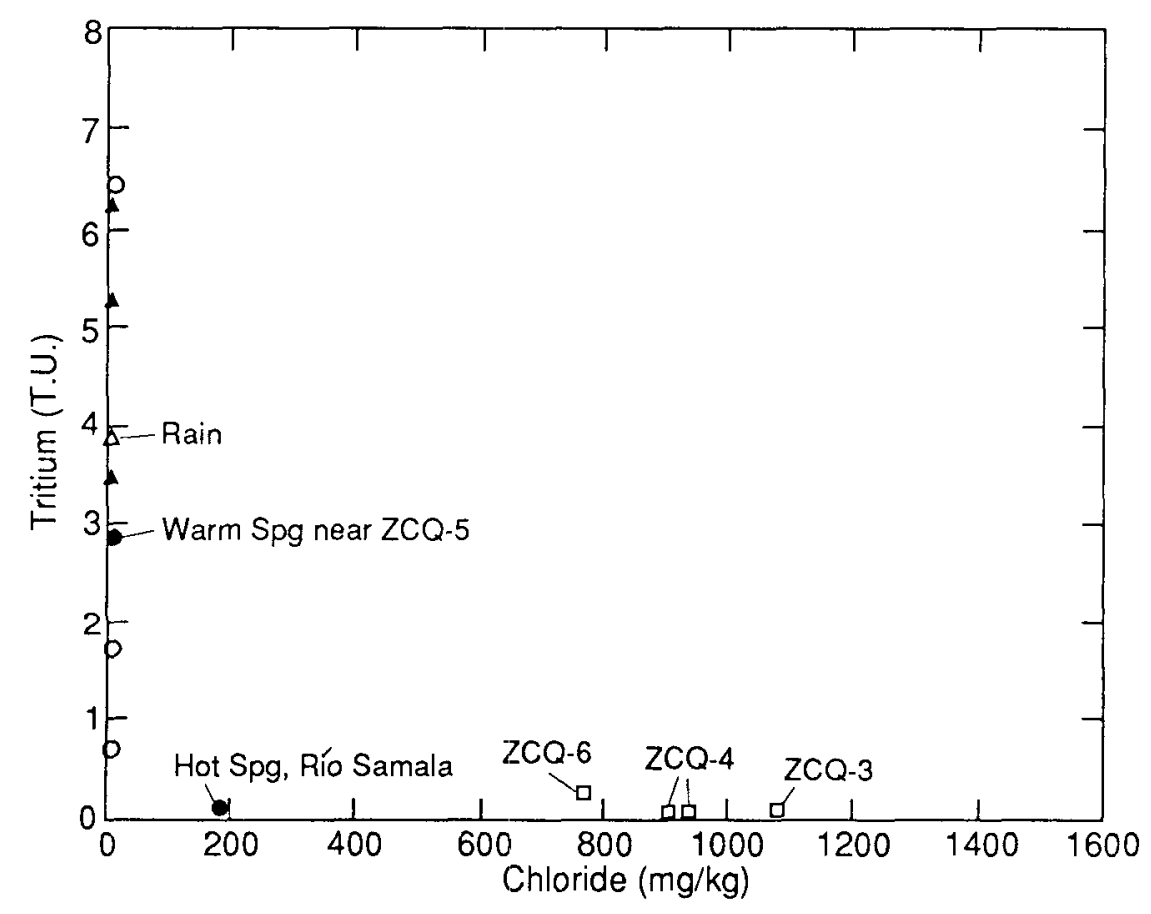

Fig. 22. Plot of tritium versus chloride for thermal and nonthermal waters of the Zunil-Quetzaltenango region, Guatemala. $\Delta=$ rainwater; $\boldsymbol{O}=$ hot/warm springs; $\square=$ well samples; $\boldsymbol{\Delta}=$ acid springs; $O=$ cold springs. 


\section{G. WELL ZC-11}

We gave special attention to slimhole ZC-11 because it is being used to supply steam to the directuse, vegetable/fruit drying facility adjacent to production well ZCQ-3. Well ZC-11 was drilled during the early 1976-1980 exploration program at Zunil to a depth of $700 \mathrm{~m}$. The well took six months to drill and, in subsequent years, had mechanical problems with the casing and wellhead assembly. These problems were partially corrected and in 1987 the well was deemed suitable for use in the joint INDE/LANL directuse project (Tobias 1987).

A steam separator constructed by INDE is connected to the side of a T-fitting at the wellhead (Tobias 1987). The Los Alamos heat exchanger and heat loop is connected to the steam side of the separator.* The other side of the T-fitting is connected to a "New Zealand" style muffler and a weirbox. Partial chemical analyses and some pressure/flow rate data are given in Tobias (1987). Additional chemical data can be found in Giggenbach (1988) and in Tables II and III. Our objective is to estimate the total flow (gas plus liquid) from the well and to obtain a chemical analysis of the downhole fluid composition.

In January 1990, the flow rate of ZC-11 was measured at the weirbox while flow was partially directed toward the heat extraction loop and while flow was directed only to the muffler. When the heat extraction loop was operating the flow rate at the weirbox was $28.6 \pm 0.9 \mathrm{e} / \mathrm{min}$ and when not operating, the flow rate was $34.2 \pm 1.5 \mathrm{e} / \mathrm{min}$. According to the casing schedule and temperature $\log , \mathrm{ZC}-11$ produced water from an open-hole section at $560 \mathrm{~m}$ and $255^{\circ} \mathrm{C}$. Chemical geothermometry suggests a lower temperature fluid may have been entering the wellbore but we have no physical means to verify this deduction (see above). Assuming the formation temperature was $255^{\circ} \mathrm{C}$, the steam fraction, $\mathrm{y}$, of the total mass flow is 0.314 (consult Henley et al. 1984, Chap. 1, and steam tables). Therefore, the total mass flow of $\mathrm{ZC}-11$ was about $49.5 \mathrm{e} / \mathrm{min}$ when the heat extraction loop received no fluid, but when the loop was operating, only $41.1 \mathrm{e} / \mathrm{min}$ passed through the weirbox. This means that roughly $8 \mathrm{e} / \mathrm{min}$ (or $17 \%$ ) of the fluid was directed toward the heat extraction loop when the drying plant was operating. For various reasons, it was not possible to collect samples off the steam separator during any of our sampling trips. Therefore, it was impossible for us to assess the quality of steam separation or to present chemical data on the steam that eventually entered the heat exchanger during drying operations. Chemical data (flashcorrected) in the tables and figures were based on samples collected either at the weirbox or from a portable steam separator mounted at the wellhead.

* Diagrams are available from $G$. Thayer, A-4, MS B299, Los Alamos National Laboratory, Los Alamos, NM 87545. 


\section{H. DISCUSSION}

Although our isotopic data are far from comprehensive, they suggest that recharge to the Zunil reservoir may come from the north and east. The different chemistries displayed by each well and differences in chemistry observed in weirbox and in situ samples suggest that the Zunil reservoir is not homogeneous and is poorly connected geochemically. The maximum mean age of water in different horizons may be as much as 500 to 7500 years.

\section{ACKNOWLEDGMENTS}

These investigations were sponsored by the US State Department Agency for International Development. We thank the well logging team from Central America that participated in the logging operations: Noé Dubón, from Guatemala; Orlando Recarté, from Honduras; and Miguel Monterrosa, Manuel Monterrosa, and Edgar Carías, from El Salvador. Others that were particularly helpful were Mike Colucci, from Southem Methodist University, for the stable isotope data; H. Gote Ostland, from the University of Miami, for the tritium data; Anthony Garcia and Ruth Bijio, from Los Alamos National Laboratory, for creating the illustrations in this report; and Carol White, Marcia Jones, and Julie Romero for word processing assistance. 



\section{APPENDIX A \\ DESCRIPTION OF LOGGING TOOLS}

Los Alamos National Laboratory furnished a new logging truck for the Central American Energy and Resources Program, complete with auxiliary generators, a data acquisition system, hydraulic-powered draw works, and associated controls. The draw works were equipped with $3000 \mathrm{~m}$ (10,000 ft) of armored cable that contains seven electrical conductors with TFE Teflon ${ }^{\circledR}$ insulation. The cable armor package is improved galvanized plow steel, and the cable is rated for continuous service at temperatures up to $320^{\circ} \mathrm{C}$.

Los Alamos National Laboratory also equipped the logging truck with wellhead apparatus required to "rig up" for deployment of the downhole instrument. (The downhole instrument is commonly referred to as the logging tool.) This apparatus includes the upper and lower sheaves, pressure lock with cooling jacket, Bowan control head (pack-off), and cable cooling system. All downhole instrument systems were designed, fabricated, and tested at Los Alamos National Laboratory. The set of logging tools consists of cableheads, a temperature probe with a casing collar locator (CCL) and ring gauge, a downhole fluid sampler, a three-arm caliper, and a fluid velocity (spinner)/temperature/pressure (STP) tool. 


\section{THE CABLEHEAD}

The cablehead (Fig A.1) is designed specifically for long-term operation in a geothermal environment where fluid temperatures exceed $300^{\circ} \mathrm{C}$. The cablehead permits termination of the sevenconductor armored cable; it completes the transition of the logging tool while ensuring watertight integrity in the high-temperature and high-pressure geothermal fluids. The cablehead can be disconnected from the armored cable should the tool stick in a wellbore.

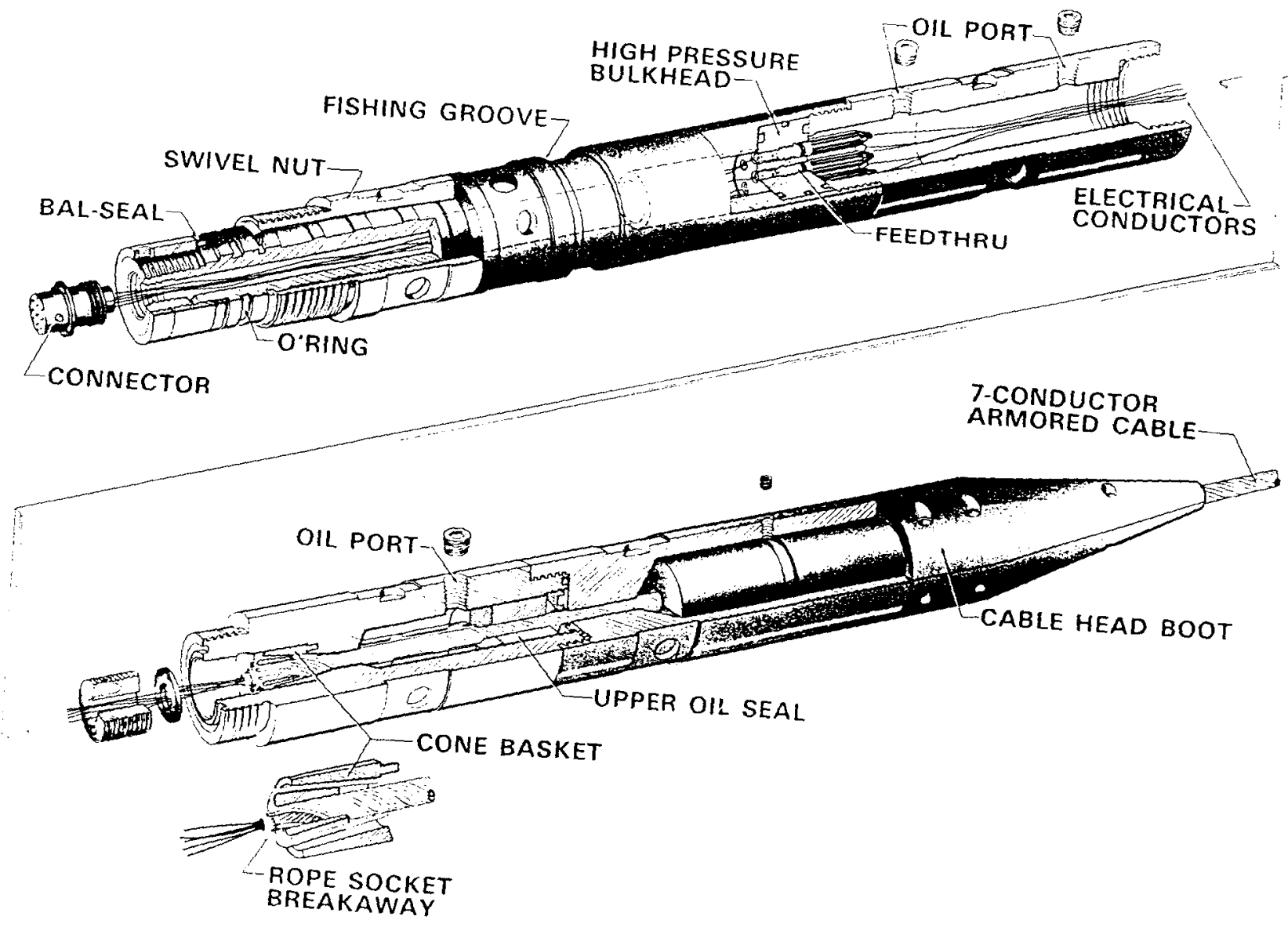

Fig. A.1. The cablehead assembly. 


\section{THE TEMPERATURE PROBE}

Borehole temperature surveys determine thermal gradients along the borehole under both static and flowing conditions. Temperature anomalies in regions where fluid flows into or out of the borehole are easily detected, so that flow zones and well lining condition can be assessed. The temperature tool includes the CCL to detect casing signatures to correct tool depth, which can be exaggerated by cable stretch. The ringgauge or "rabbit" is attached to the pressure housing to gauge the borehole diameter (Fig. A.2). The temperature probe with the CCL and rabbit is run first in every wellbore before the borehole is logged with the more expensive, complex instrument packages.

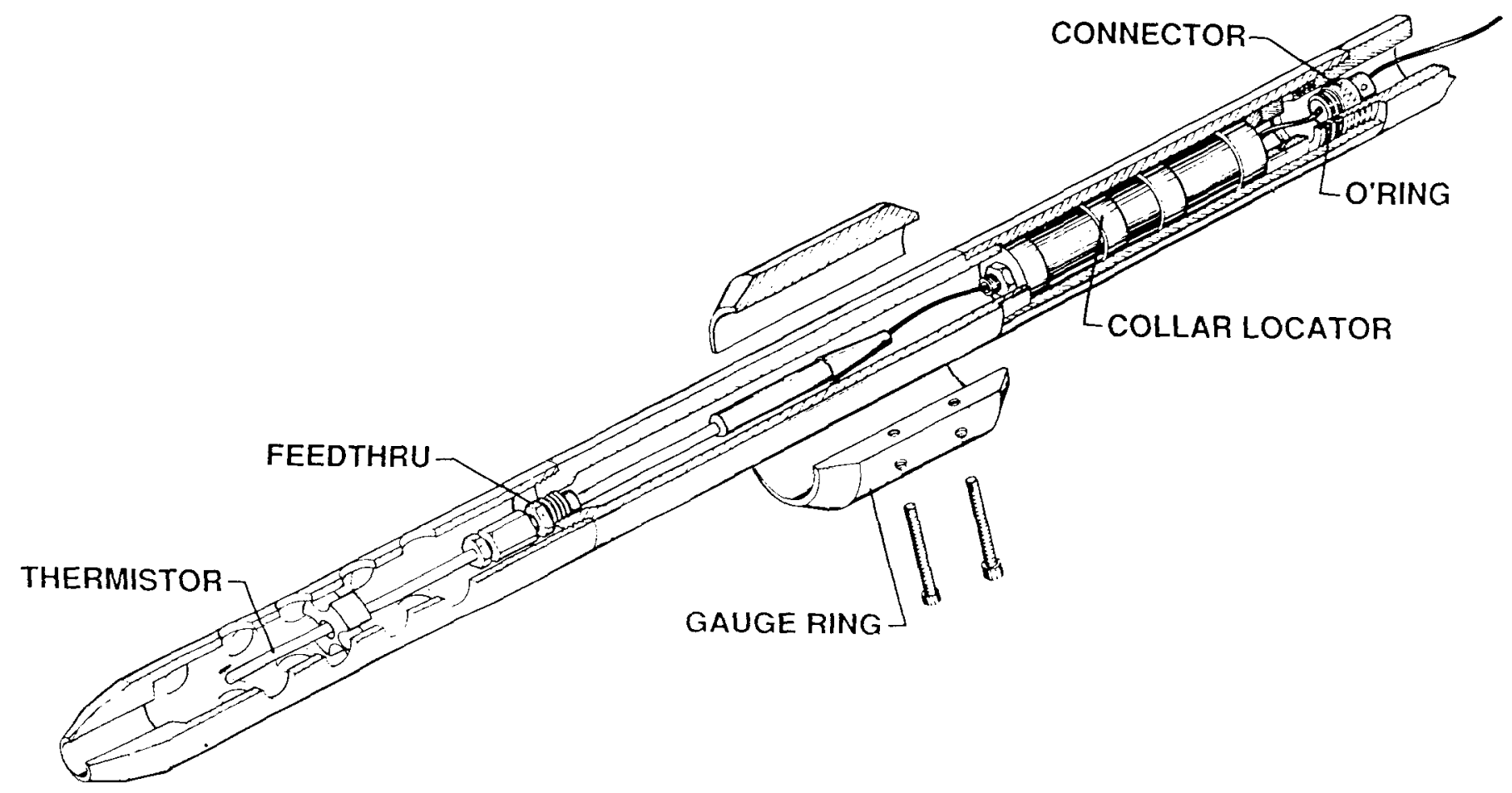

Fig. A.2. The temperature/rabbit tool. 


\section{LOS ALAMOS IN SITU SAMPLER}

The Los Alamos in situ sampler is described in Archuleta et al. (1978) and, its field application is reported in Goff et al. (1987a) and Grigsby et al. (1989) (Fig. A.3). The sample bottle is evacuated at the surface and the tool is then lowered to the desired depth by a seven-conductor armored cable. The sample chamber valve is opened by a temperature-hardened motor that is controlled electrically from the surface. The sample chamber is then closed by reversing polarity on the circuit. When the sampler returns to the surface, it is cooled to $<70^{\circ} \mathrm{C}$ to prevent any loss of steam before the pressurized sample is removed. A temperature well in the valve assembly cap extends into the sample bottle to provide a means of monitoring the internal temperature of the sample. A gas extraction system (GES) (Fig. A.4) is used to quantitatively remove the gaseous portion of the sample from the sample bottle. Goff et al. (1987a) gives a more complete description of GES procedures. 


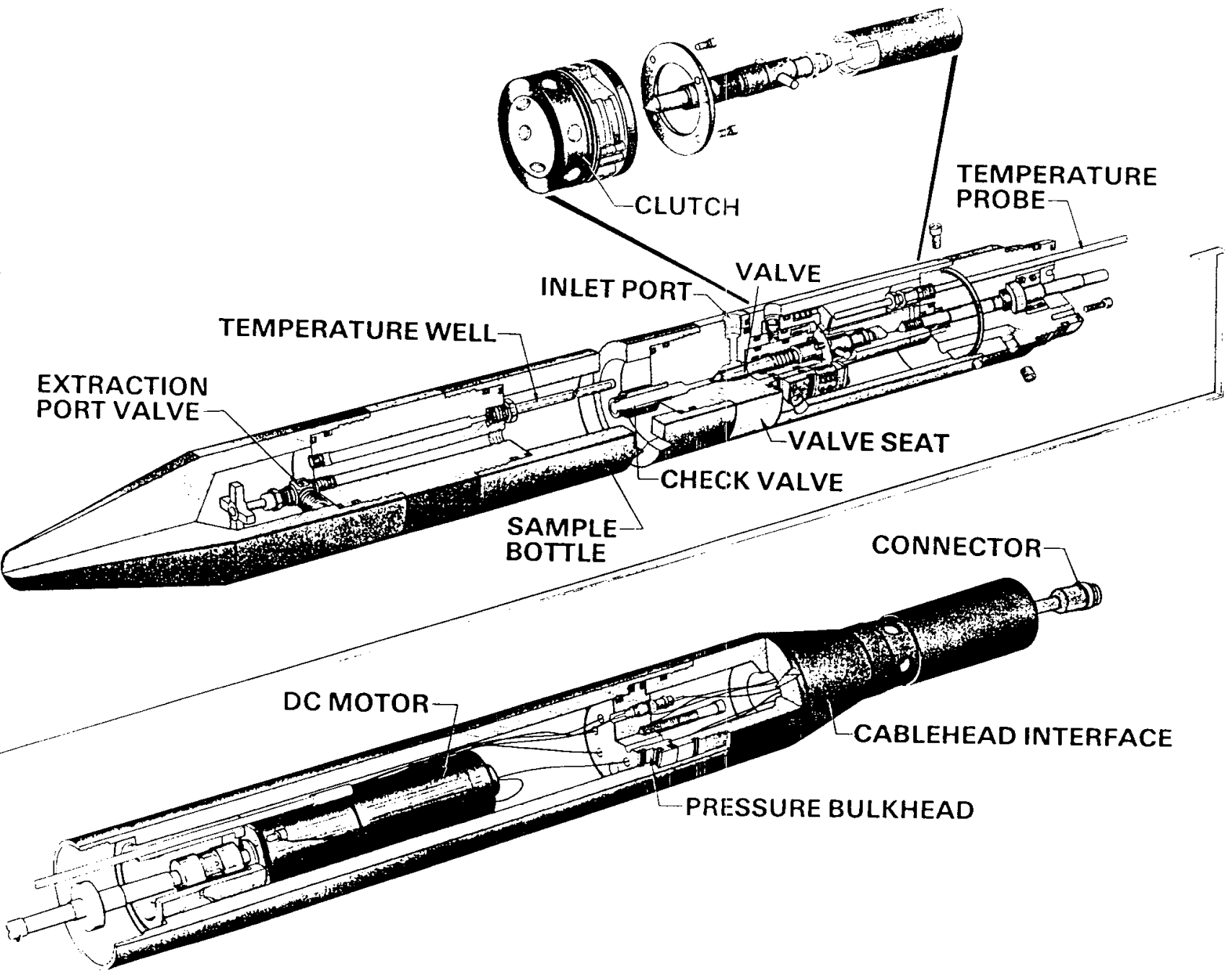

MOTOR DRIVE SHAFT

Fig. A.3. Schematic diagram of the Los Alamos fluid sampler used during this investigation. 
After extraction of the gaseous portion of the sample, the tool is opened and the geothermal brine is poured into a tared beaker and the mass weighed on a top-loading balance. In this case, the brine contained less than $10,000 \mathrm{mg} / \mathrm{kg}$ chloride; thus, the brine density was not calculated in the field. The density is assumed to be 1.0 at $25^{\circ} \mathrm{C}$. An aliquot of sample is used to determine $\mathrm{pH}$ and any other parameters that a geoscientist may wish to measure in the field. The remainder of the sampler is split and preserved for various chemical and isotopic analyses. Procedures for collecting the other Zunil samples discussed in this report vary depending upon the situation (spring, fumarole, weirbox, etc.). Trujillo et al. (1987) discusses methods of collection and preservation of samples.

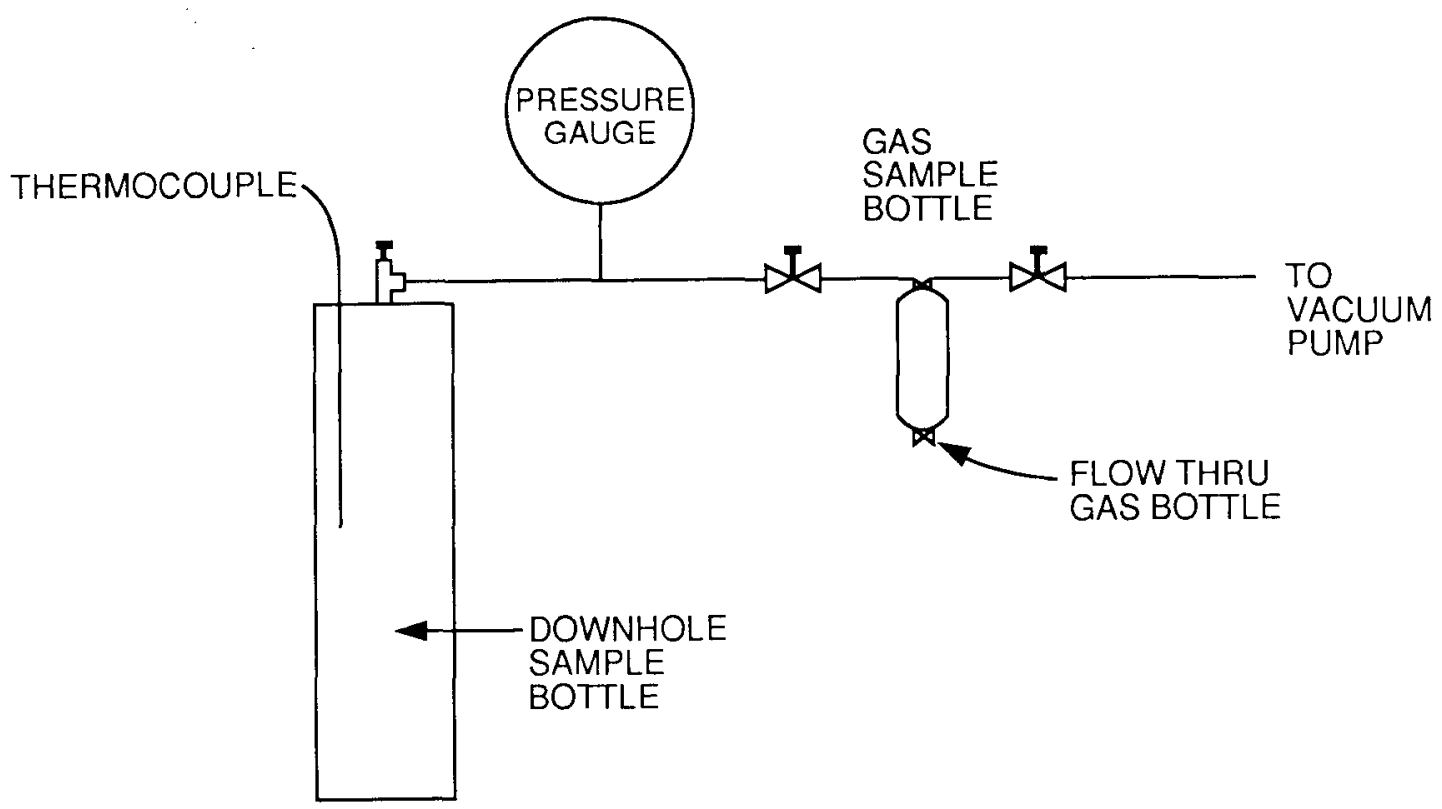

Fig. A.4. Gas extraction system used in operations at the Zunil geothermal field, Guatemala. 


\section{THE THREE-ARM CALIPER}

Borehole conditions, such as open-hole or casing diameters, contour, wear, scale accumulations, breakouts, etc., can be measured with the three-arm caliper tool. The three arms, which are spaced $120^{\circ}$ apart on the circumference, operate independently (Fig. A.5). Normally, the caliper tool is deployed in the borehole, with the arms retracted, to the lowest depth of interest. The arms are then extended by applying current to the downhole dc motor and associated drive. When fully extended, the arms provide a moderate spring-activated force against the borehole or casing wall. The tool is then pulled up the borehole, and the motion of each arm, as it follows the contour, is transformed to a rotational motion sensed by a cosine-type potentiometer. The output signal of each of the three potentiometers is a function of the radius from the center line of the centralized tool to the tip of the arm. Caliper calibration is verified before each log.

1. D.C. MOTOR, HIGH TEMP.

2. BAL-SEALS NO. 505

3. BALL BEARINGS NDH

4. LEAD SCREW (17-4 SST)

5. CENTRALIZERS (12)

6. ARM (3)

7. BEAD CHAIN

8. MAGNET, ALNICO 5-7 (12)

9. POTENTIOMETER (3)

10. O-RING

11. COVER

12. BULKHEAD FEED THROUGH
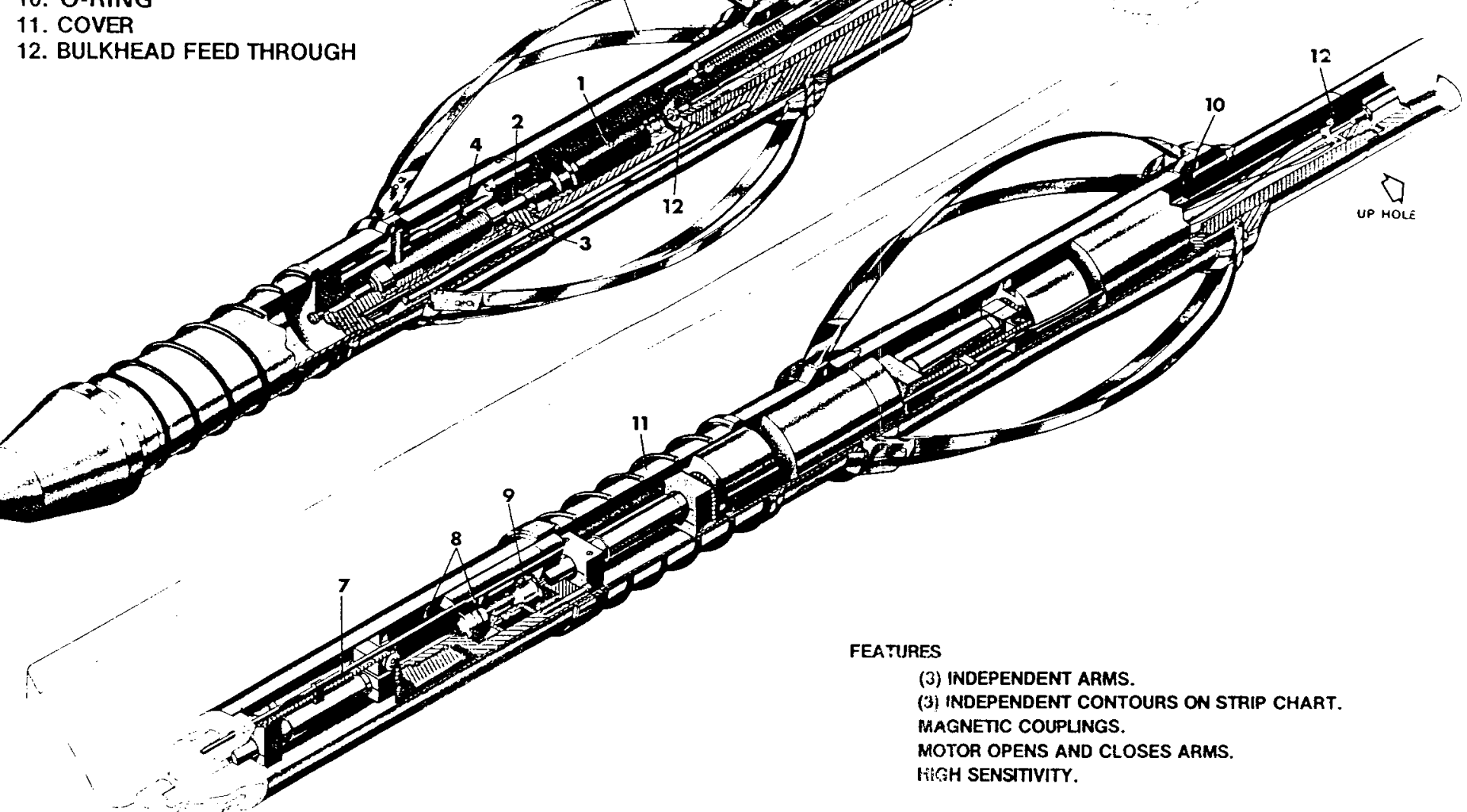

FEATURES

(3) INDEPENDENT ARMS.

(3) INDEPENDENT CONTOURS ON STRIP CHART. MAGNETIC COUPLINGS. MOTOR OPENS AND CLOSES ARMS. HIIGH SENSITIVITY.

Fig. A.5. The three-arm caliper tool. 


\section{SPINNER/TEMPERATURE/PRESSURE TOOL}

To determine the thermodynamic state of a flowing borehole, simultaneous measurements of temperature, pressure, and fluid velocity are necessary. A high-temperature $\left(300^{\circ} \mathrm{C}\right)$ well logging tool was developed specifically to measure these parameters in the production wells in Central America. This tool is referred to as the spinner/temperature/pressure or STP tool. The fluid velocity transducer (spinner) incorporates a rotating impeller with hardened steel pivot bearings (the spinner end of the tool is shown in Fig A.6). The rotating shaft operates a reed switch that transforms the rotational speed of the impeller to pulses recorded as frequency in hertz. The rotational speed in hertz is proportional to the velocity of the fluid relative to the logging tool. A proportionality constant is determined by logging the liquid-filled region of the borehole. The temperature sensor is a thermistor that has been calibrated to an accuracy of $0.10^{\circ} \mathrm{C}$ up to $300^{\circ} \mathrm{C}$. This temperature sensor provides very fast response and exceptional resolution. The pressure transducer provides accurate pressure measurement in the geothermal fluids when meticulous calibration producers are used. Pressure measurements are made in the STP tool with a $0-$ to $34.5-\mathrm{MPa}$ (5000 psi) potentiometer gauge pressure transducer. The constant current excitation is sensed at the pressure gauge so that the power supply at the surface can compensate for line losses over the $3000-\mathrm{m}$ armored cable. 


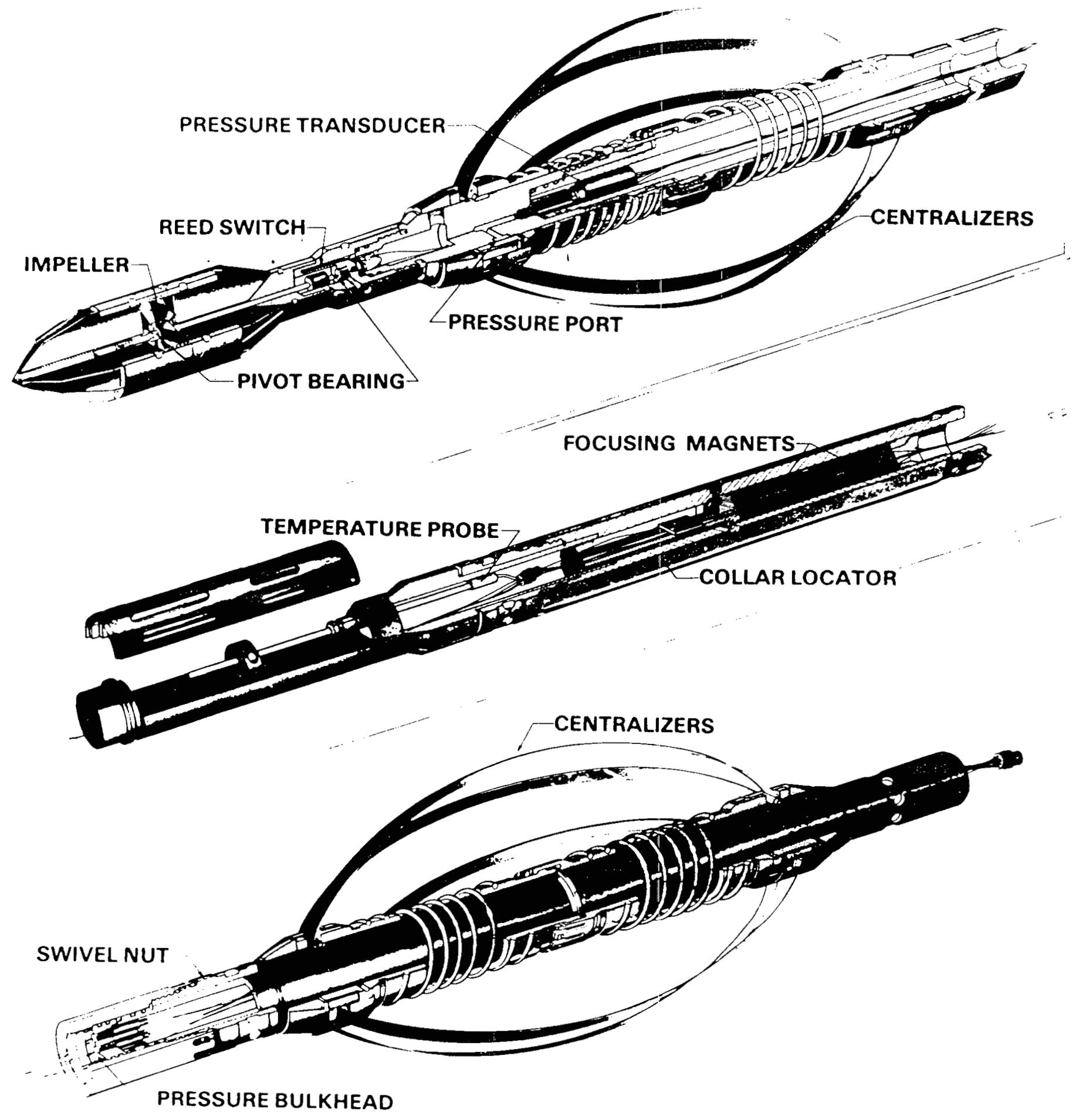

Fig. A.6. The spinner/temperature/pressure tool. 


\section{REFERENCES}

Adams, A., Goff, F., Trujillo, P. E. Counce, D., Medina, V., Archuleta, J., and Dennis, B., "Hydrogeochemical Investigations in Support of Well Logging Operations at the Zunil Geothermal Field, Guatemala," Geotherm. Res. Counc. Trans. 14, (1990)(in press).

Archuleta, J. R., Fink C. F., and Kurtenbach, J., "Equipment Development Report: Borehole Fluid Sampling Tool," Los Alamos Scientific Laboratory report LA-7152 (February 1978).

D'Amore, F., and Panichi, C., "Evaluation of Deep Temperatures of Hydrothermal Systems by a New Gas Geothermometer," Geochim. Cosmochim. Acta 44, 549-556 (1980).

Fournier, R. O., "Application of Water Geochemistry to Geothermal Exploration and Reservoir Engineering," in Geothermal Systems: Principles and Case Histories, L. Ryback and L. J. P. Muffler, Eds. (John Wiley and Sons, New York, 1981), pp. 109-143.

Foumier, R. O., Hanshaw, B. B., and Urrutia Sole, J. F., "Oxygen and Hydrogen Isotopes in Thermal Waters at Zunil, Guatemala," Geotherm. Res. Counc. Trans. 6, 89-91 (1982).

Giggenbach, W.F., IAEA Coordinated Research Program on the Application of Isotopic and Chemical Techniques to Geothermal Exploration in Latin America: The Isotopic and Chemical Composition of Water and Steam Discharges from the Lago de Amatitlan, San Marcos, and Zunil Geothermal Fields, Guatemala," unpublished IAEA report (1986).

Giggenbach, W.F., IAEA Coordinated Research Program on the Application of Isotopic and Chemical Techniques to Geothermal Exploration in Latin America: Report on the Isotopic and Chemical Composition of Water and Steam Discharges from the Zunil, Tecuamburro, and Moyta Geothermal Fields, Guatemala," unpublished IAEA report (1988).

Goff, F., Shevenell, L., Grigsby, C. O., and Dennis, B., Eds., "Downhole Fluid Sampling at the SSSDP California State 2-4 Well, Salton Sea, California," Los Alamos National Laboratory report LA11052-OBES (July 1987a).

Goff, F., Truesdell, A. H., Grigsby, C. O., Janik, C. J., Shevenell, L., Paredes, J. R., Gutierrez, J., Trujillo, P. E., and Counce, D., "Hydrogeochemical Investigations of Six Geothermal Sites, Honduras, Central America," Los Alamos National Laboratory report LA-10785-MS (June 1987b).

Grigsby, C. O., Goff, F., Trujillo, P. E., Counce, D. A., Dennis, B., Kolar, J., and Corrales, R., "Results of Investigations at the Miravalles Geothermal Field, Costa Rica: Part 2: Downhole Fluid Sampling," Los Alamos National Laboratory report LA-11510-MS, Part 2 (October 1989)

Hedenquist, J. W., Goff, F., Phillips, F. M., Elmore, D., Stewart, M. K., and Taylor, C. B., "Groundwater Dilution and Residence Times in the Mokai Geothermal System, New Zealand, from Domical Stable Isotope, Titium, and ${ }^{36} \mathrm{Cl}$ Data," to be published in J. Geophys. Res.

Henley, R. W., Truesdell, A. H., and Barton, P. B., Fluid-Mineral Equilibria in Hydrothermal Systems (Econ. Geol. Pub. Co., El Paso, Texas, 1984).

MK-Ferguson Co., "Geothermal Power Plant Zunil I Quezaltenango, Misión de Enfoque report," (Instituto Nacional de Electrificación, Guatemala City, Guatemala, 1988). 
MK-Ferguson Co., "Planta Geotermoeléctrica de 15 MW, Proyecto Zunil I Quetzaltenango," Geoscientific Studies Report No. 1, (Instituto Nacional de Electrificación, Guatemala City, Guatemala, 1988).

Norman, D. I., and Bernhart, C., "Assessment of Geothermal Reservoir by Analysis of Gases in Thermal Waters," New Mexico Energy Institute, Final Report EMD \# 68R-2305 (1981)

Person, F. J., and A. H Truesdell, "Tritium in the Waters of Yellowstone National Park," US Geol. Surv. Open-File report 78-710 (1978).

Tobías, E., "Informe Final de Produccion del Pozo ZC-11," Unpublished report, (Instituto Nacional de Electrificación, Guatemala City, Guatemala, 1987).

Trujillo, P. E., Counce, D., Grigsby, C. O., Goff, F., and Shevenell, L., "Chemical Analysis and Sampling Techniques for Geothermal Fluid and Gas at the Fenton Hill Laboratory," Los Alamos National Laboratory report LA-11006-MS (June 1987). 